University of Michigan Law School

University of Michigan Law School Scholarship Repository

Articles

Faculty Scholarship

1995

\title{
Freedom and Criminal Responsibility in the Age of Pound: An Essay on Criminal Justice
}

Thomas A. Green

University of Michigan Law School, tagreen@umich.edu

Available at: https://repository.law.umich.edu/articles/136

Follow this and additional works at: https://repository.law.umich.edu/articles

Part of the Criminal Law Commons, Jurisprudence Commons, Legal History Commons, and the Natural Law Commons

\section{Recommended Citation}

Green, Thomas A. "Freedom and Criminal Responsibility in the Age of Pound: An Essay on Criminal Justice." Mich. L. Rev. 93, no. 2 (1995): 1915-2053.

This Article is brought to you for free and open access by the Faculty Scholarship at University of Michigan Law School Scholarship Repository. It has been accepted for inclusion in Articles by an authorized administrator of University of Michigan Law School Scholarship Repository. For more information, please contact mlaw.repository@umich.edu. 


\title{
FREEDOM AND CRIMINAL RESPONSIBILITY IN THE AGE OF POUND: AN ESSAY ON CRIMINAL JUSTICE
}

\author{
Thomas A. Green*
}

\section{INTRODUCTION}

The concept of freedom has two main aspects: political liberty and freedom of the will. I am concerned here with the latter, although - as these two aspects of freedom are not entirely unrelated to each other - I shall touch also on the former. Enough has been written from a philosophical perspective on the relationship between free will and the law that it is not easy to justify yet another such undertaking. But there may still be room for some informal observations on the manner in which doubts about the concept of freedom of the will affected discussion of criminal responsibility in early-twentieth-century America - room for reflections that might also serve as a backdrop to more presentist concerns.

The occasion for this essay - the inauguration of the Dawson chair at the University of Michigan Law School - has not commanded its subject matter. ${ }^{1}$ Nonetheless, it is worth noting that

* John Philip Dawson Collegiate Professor of Law, University of Michigan. A.B. 1961, Columbia; A.M. (History) 1962, Ph.D. (History) 1970, J.D. 1972, Harvard. - Ed. This essay is drawn from my on-going work on the American criminal trial jury and concepts of freedom (1800-present). I want to recognize here the generous support I have received in connection with this long-range project from the Center for Advanced Studies in the Behavioral Sciences (and the Andrew W. Mellon Fund), the National Endowment for the Humanities, the John Simon Guggenheim Memorial Foundation, and the William W. Cook Endowment Fund of the University of Michigan Law School.

Many colleagues, here at Michigan and elsewhere, have read and commented upon earlier drafts of parts of this essay. I thank them for their help and support. Special thanks are due to Steven Croley, Phoebe Ellsworth, Kate Gilbert, Hendrik Hartog, Donald Herzog, Diane Lehman, Margaret Sommers, and Peter Westen. And most of all, I thank Elizabeth Clark for substantive and editorial criticism of the entire manuscript - labor well beyond the call of duty. My principal research assistant, Erik McKee, and research assistants Warren Rosenblum and Christopher Taylor, deserve special appreciation. Louis Anthes kindly reviewed the Speranza papers at the New York Public Library for me. Finally I thank my secretary, Sharon Rice, for her extraordinary assistance and patience throughout the period during which the constituent elements of the current essay evolved. No words can express my appreciation to my wife, Ruth Brownell Green, whose support over the years has meant everything.

1. The John Philip Dawson Collegiate Professorship of Law was established in 1990 to commemorate Professor Dawson's years at the University of Michigan Law School (1927- 
Professor Dawson touched upon the freedom question some fortyodd years ago in his important article on economic duress. ${ }^{2}$ Dawson there pointed to doctrine that made evidence of consent a test for whether there had been the complete destruction of the will that the law of duress sometimes required: "[C]ourts had been slow to realize that the instances of more extreme pressure were precisely those in which the consent expressed was more real; the more unpleasant the alternative, the more real the consent to a course which would avoid it." 3 This tendency of thought - which Dawson saw as paradoxical - was not of course universal. Progressive-era courts, as Professor Dawson proceeded to show, came to focus on the unfairness involved in the enforcement of contracts that resulted from greatly unequal bargaining power. For these courts one infers - the legal presumption that the weaker party's choice was freely made was indeed open to question. That party's freedom - or lack of freedom - was, however, a purely relative matter. The more general issue of whether humans could ever act with free will did not often arise. There were some doubts in the culture at large about this ultimate capacity for human autonomy, but these tended not to penetrate the legal sphere. There were a few exceptions to this, as we shall shortly see, but they rarely involved marketplace relations. For the most part, contemporaries saw the problem of freedom in the marketplace as resulting solely from superior bargaining power, and they thought that this problem could be remedied by resettling the conditions that determined that power - by restoring the dominated actor to relatively equal footing with the dominant actor.

The concepts of freedom and equality are thus close cousins. To be on equal footing means, in our legal, political, and social culture, to be free - at least this seems true on the surface, where the law has long dwelled, and where perhaps it ought to remain. Barring circumstances of gross inequality, freedom is the central presumption of the law.

The most important exception is the domain of criminal jurisprudence, where doubts about the ultimate capacity for human freedom have penetrated both jurisprudence and the practical application of the law. Even here, however, the extent of the incur-

58). Professor Dawson was one of Michigan's great scholars and teachers. I am honored to be the first holder of the Dawson Chair.

2. John P. Dawson, Economic Duress - An Essay in Perspective, 45 Mrcr. L. Rev. 253 (1947).

3. Id. at 267. 
sion has been limited by the deployment of mechanisms of evasion. Typically, we have entertained our doubts at the sentencing phase of the criminal process, where the ultimate issue of responsibility is less prominently involved, and allowed our "progressive" approach in that context to disguise from ourselves how little we have confronted the implications of our doubts at the trial stage, where responsibility is most directly involved. This largely unselfconscious maneuver has led to a substantial degree of incoherence in both the theory and the practice of our system of criminal justice, even as it has borne testimony to our determination to uphold the underlying concept of human free will.

Our approach to both trial and punishment has also evidenced our concern with the other concept of freedom: political liberty. For the progressive notion that those who have committed crimes have done so as a result of circumstances over which they had little or no control has vied with the progressive 4 notion that limits on state intrusion into the life of the individual quickly evaporate when all human behavior is viewed in this fashion. Freedom from the state presumes - even requires - that the law be premised upon the possibility of human freedom.

The plan of this essay is as follows. I begin with a sidelong glance at some features of fin de siècle criminal jurisprudence, which I approach through a reading of a few papers written at the outset of his career by a little-known New York lawyer, Gino Speranza. Strongly influenced by the behavioral science of his day, Speranza reflected a radical perspective shared by few contemporary practitioners - or academic legal theorists. Speranza represented a movement that brought deterministic ideas from the behavioral and social sciences into law. In that respect he stands as a kind of missionary to lawyers from "scientists." But Speranza soon discovered that the limits of common lawyers' own cultural traditions largely prevented the assimilation of determinism into law, and came to appreciate the conservative value of some of those traditions. Speranza illustrates the limits beyond which few American lawyers of the day would proceed in assimilating the social and behavioral sciences. He thus helps to define the scope of the problem that the legal profession confronted.

4. I use the term "progressive" (lower case) in its conventional sense. I use the term "Progressive" (upper case) to refer to the ideas associated with the Progressive Era (roughly, for my purposes, 1895-1920, though I refer to its early years as the fin de siecle). Often, the ideas associated with the two terms overlap, but some "progressive" ideas were not so clearly in the mainstream of the Progressive program. 
I turn in Part II, the main section of this essay, to a lengthy odyssey: the evolution of Roscoe Pound's criminal jurisprudence, from 1905 to 1923. Born in Lincoln, Neraska, in 1870, Pound was, of course, a leading legal academic of the early twentieth century, serving first as a member, then as Dean, of the Nebraska law faculty and thereafter on the law faculties of Northwestern and Chicago. He moved to Harvard in 1910, where he was Dean from 1916 to 1936. Pound continued to write until his death in 1964, although his truly creative period had ended by the 1930 s. With respect to criminal jurisprudence, Pound was potentially an odd man out, for he appears in his own thinking to have rejected the concept of free will as an element of mens rea. Pound nonetheless managed to retain a resolutely juristic perspective, always keeping safe distance from the hard-core determinism of much Progressive-era criminology and penology. He was an avowed assimilationist, and his writings reflect the strains that are the lot of the common lawyer who would join the insights of law and science. In his own way, Pound sought to meet the challenge of the fin de siècle, to resolve what Speranza had deemed unresolvable. He looked forward to, but never clearly articulated, a gradual reform of all aspects of criminal justice administration that would meld the principles of social and behavioral science with the imperatives of legal science and maintain respect for the claim of human freedom. Pound's approach - eclectic, unsystematic - sought to apply selectively the learning of the social and behavioral science of his day in order to achieve overall coordination of ideas and institutions. He overlooked inherent contradictions, unselfconsciously adopting an evasive approach to the most difficult problems. Though his achievement was significant by the standards of his times, as a foundational work in criminal jurisprudence it fell short of the leading accounts of the 1930s and beyond. More history, impressionistic sociology, and commentary on contemporary legal practices than analytical jurisprudence, Pound's contribution to modern criminal justice study has been largely forgotten - mined for aphorisms but not appreciated as the fine tapestry that it is. I tell Pound's story both for its own sake and as an introductory foray into the history of early twentieth-century criminal jurisprudence. For the most part, I let Pound speak for himself. (Indeed, the entire essay is largely devoted to recovering voices that have long-since drifted away, been recorded-over by our own idiom as we have addressed the same issues.) While I remain agnostic as to whether Pound was representative, I see him as part of the progressive juristic vanguard and as a true Progressive. Few other 
American legal scholars of the pre-1923 period wrote much of a sustained sort on the problem of criminal jurisprudence; generalizing from the random comments of the day is of limited help in this regard. There is a fuller, far more contextual tale to be told of that period, but that tale remains for a later occasion.

Part III recreates what might be called a conversation among a number of commentators on criminal justice, from 1923 to 1930. The "conversation" - of which I recount only some high points is meant to bring Pound's story to a close and to put Pound in perspective. It also serves to introduce what I see as the beginning of a new era, one marked not so much by new issues as by new energy and increased attention to those issues already within the legal academy. From a presentist perspective, Pound's story matters because his work dealt with problems forced on lawyers by "scientists" that remain at the foundation of our thinking about criminal justice. Despite all that has happened since the mid-1920s, the era toward which Part III points, Pound's story remains, in a special sense, largely our own. Our analyses of criminal jurisprudence go far deeper, and we are attentive to ultimate contradictions that Pound seems not to have confronted. Nonetheless, we build on the same shaky foundations, partly recognizing that it is the best we can do; partly, but only indirectly, taking the infirmities into account; partly forgetting along the way how much we rest matters of life and liberty on theories that resist verification - indeed, that invite strong skepticism.

I address by way of a brief Epilogue some aspects of the modern context in which our own odysseys take place.

\section{The FIN DE SIËCLE: Speranza}

Writing in 1901, in the pages of a legal magazine, The Green $\mathrm{Bag}$, a young member of the New York bar named Gino Speranza stated: "Law is one of the humanities."' So it is, but what caused Speranza to say so in such an insistent tone in his article, The Medico-Legal Conflict over Mental Responsibility? Perhaps Speranza's true audience was scientists whose specialization was the science of human behavior and its application to the treatment and cure of criminal offenders. Many of them had trained abroad or at home on the writings of late nineteenth-century European criminologists and penologists, forming a large phalanx of Western students

5. Gino C. Speranza, The Medico-Legal Conflict over Mental Responsibility, 13 GREEN BAG 123, 125 (1901). 
of human behavior whose approach was decidedly deterministic. Within this transnational movement there were, to be sure, distinct schools: some gave primacy to hereditary factors, others stressed environmental influences. Systems of classification of criminal types abounded; not everyone agreed about what to do with incorrigibles. But the dominant approach to criminal behavior was deterministic. Indeed, for many of these scientists, all behavior like all events in nature - had its causes, and the will itself, whether it gave in to desires or resisted them, was the plaything of forces that it did not ultimately create or control. For these strong determinists, whatever value the concept of free will had in more speculative areas of life, everything that science could know about human behavior could be understood without invoking that concept. 6

6. While much has been written on late nineteenth-century conflicts over the definition of insanity and its relation to criminal responsibility, a comprehensive account of American penology and criminology has not appeared in recent years. Nonetheless, it is by now a familiar fact that American "scientists" began to develop deterministic theories of crime by the first half of the nineteenth century. The development of American psychiatry and the scientific exploration of responsibility, including the idea of moral insanity, is discussed in Charles E. Rosengerg, The Trial of the Assassin Guiteau: Psychiatry and Law in THE GIIDED Age 61-74, 100-06, 243-58 (1968). See also Janet Ann Tighe, A Question of Responsibility: The Development of American Forensic Psychiatry, 1838-1930, at 25.68 (1983) (unpublished Ph.D. dissertation, University of Pennsylvania); NORMaN DaIn, CoNCEPTS OF INSANITY IN THE UNITED States 1789-1865 (1964). ARTHUR E. FinK, CaUSES OF Crime: Biological TheorIes IN THE UnIted States, 1800-1915, at 1-19 (1938), notes the early popularity of phrenology in America. British criminology exercised an enduring influence on American thought, and British developments are discussed in MARTIN J. WIENER, Reconstructing tHe CRMINAI: Culture, LaW, AND Policy In ENOLAND, 1830-1914 (1990). Late-Victorian British criminology and penology are the focus of DAVID GaRLAND, Punisiment and Welfare: A History of Penal Strategres (1985). Continental criminal anthropology and criminological theories began to affect American thinking on crime by the $1870 \mathrm{~s}$. Broadly speaking, the European influence centered on the Italian school's focus on heredity, stemming from the work of Lombroso, Ferri, and Garofalo, and the role of environment, generally associated with the French school of Tarde, Lacassagne, and others. For a description of the development of each school and the relationship and tensions between them in Europe, see RUTH HaRRIS, MURDERS aNd MADNESS: MEdICINE, LAW, AND SOCIETY IN THE FIN DE SIECLE 80-98 (1989); Robert A. NYE, CRIME, MAdNess, and PolItics in Modern France: The Medical Concept of National Decline 97-131 (1984); Gordon Wright, Between the GuILlOtINe AND LIBERTY: Two Centuries of the Crme Problem In France 119-28 (1983). For their influence in America, see Francis A. Allen, The Decline of the Rehabintative Ideal: Penal Policy and Social Pur. POSE 40-44 (1981); FINK, supra, at 99-150. The classic early example of American theories of crime and heredity is R.L. Dugdale, "The JukEs": A STUDY In CRIME, PAUPERISM, DisEASE, AND Heredity (New York, G.P. Putnam's Sons 1877), which LAWRence M. FrIedman, Crime AND Punishment in AMERICAN History 140-42 (1993), correctly relates to the development of eugenic theories. Though Dugdale also emphasized environmental influences, this aspect of his work was largely passed over by contemporaries. See also infra note 62. On specific European criminologists, see Proneers IN CRIMINorogy (Hermann Mannheim ed., 1960). Not all observers of crime were strongly deterministic, in the sense of believing that "normal" individuals were also determined; some were and some were not. See, for example, Craig Haney's important article, Criminal Justice and the Nineteenth-Century Paradigm: The Triumph of Psychological Individualism in the 'Formative Era', 6 LAw \& HUM. BEFAV. 191 (1982). Haney argues that the movement for individualization in the early 
There was nothing new about the concept of determinism. Men had reasoned their way to it long before the late nineteenth century. For some, the concept of an omniscient God had rendered the notion of human free will logically impossible or even downright blasphemous. For others, the general concept of cause and effect led to determinism long before modern science reinforced that view. Indeed, a deterministic, or "naturalist," position characterized various currents of thought regarding criminal justice in the United States since at least the late eighteenth century. ${ }^{7}$ What was new in fin de siècle America was the pervasiveness of deterministic theory among practitioners of applied behavioral science, and few areas of social policy were so profoundly affected as were the fields of criminology and penology. From these fields, the influence of determinism spread to other domains of the law, though the impact was greater in some areas than in others, and though - as we shall see - the law ultimately fought off the worst ravages of the disease.

In Speranza's day, behavioral science was recognized by the legal profession - as by educated Americans generally - as a

Progressive period grew out of the longstanding focus in nineteenth-century America on individual responsibility. Haney's account suggests that for many fin de siecle criminologists and penologists - as for psychologists as well - the ideology of "psychological individualism" maintained a belief in free will by describing criminal behavior as the product of a moral disease. These same criminologists and penologists, it seems to me, were nonetheless deterministic in their methodology and in much of their analysis. Additionally, determinism was sometimes applied to the study of race and other issues not directly related to crime. See, e.g., Stephen JAy Gould, The Mrsmeasure of MAN 30-69 (1981). Nonetheless, among scientists interested in criminals, the issue was not so much the debate over strong versus narrow determinism, but over the specific "causes" of crime and the stigmata of criminals. Thus, conflicts evolved concerning the relationship between brain structure and behavior, the existence of physiological characteristics peculiar to criminals, the possibility of atavistic degeneration through heredity and the consequent development of "born" or "instinctive" criminals. The varieties of American deterministic thinking displayed in these debates, and the generally deterministic assumptions of many scientists, are especially apparent in the Medico-Legal Journal of the New York Medico-Legal Society, the published annual proceedings of the National Prison Association, and in the increased participation of Americans in international congresses on crime, criminals, and penology. For a discussion of determinism in American studies of the causes of crime, see, for example, MERLe CuRTI, Human NATURE IN AMERICAN THOUght 273-312 (1980); FinK, supra; LARRY K. HARTSFIELD, THE AMerican Response to Professional Crime, 1870-1917, at 149-88 (1985); Herbert Hovenkamp, Insanity and Criminal Responsibility in Progressive America, 57 NOTRE DAME L. Rev. 541 (1981); Tighe, supra, at 234-92.

7. Some of these currents are reflected in, for example, DAVID J. ROTHMAN, THE DIsCOVERY OF THE ASYLUM: SOCIAL ORDER AND DISORDER IN THE REPUBLIC 59-78 (1971). See also David Brion Davis, From Homidne to Slavery: Studies In AMERICAN Cul TURE 18-26 (1986); FINK, supra note 6, at 1-19; JoN PAHI, PARADOX LOST: FReE WILL AND POLITICAI LIBERTY IN AMERICAN CULTURE, 1630-1760, at 6-9 (1992). Pahl describes a continuum of thought concerning theological and philosophical approaches to free will and determinism in colonial America, and argues that these theological debates had direct ties to visions of political liberty. See also ALLEN, supra note 6, at 3-16, 40-44. 
breakthrough of considerable importance. It held out the possibility of a solution to the problem of criminal behavior that greatly concerned both Europe and America. Its principles, many thought, would lead to the rehabilitation of those criminals who were not biologically, or otherwise, beyond salvation: If one understood why people behaved as they did, one might then design an environment that would reform the behavior of most - perhaps even the majority - of those persons with criminal tendencies. The implications of the new penology that took root in the Gilded Age and flowered in the Progressive Era were many, however, and among them was the message that humans were not responsible for their behavior, a message that the legal profession and society at large were unwilling to accept. For most Americans (I hazard the guess), Progressive-Era penology came to stand for the idea that rehabilitation involved a process of strengthening the will of persons who, by reason of one or another social influence, had been unable to resist the temptation to break the law. ${ }^{8}$ Thus, for society as a whole, the new concepts of human behavior were made compatible with the traditional notion of free will - a marriage that provided a lasting, if uneasy, conceptual framework that has survived the decline of the rehabilitative ideal. 9

At the time that Speranza wrote, the major elements of Progressive-Era penology were still in the theoretical stage; application would soon follow. In Speranza's circles, optimism regarding the new penology was guarded. The lay conclusions that most Americans wanted to draw about the relationship between free will and rehabilitation seem not to have concerned most behavioral and medical scientists: For the moment, at least, it was the principles of treatment that counted - and the question whether these were headed for general acceptance and for the political support crucial to obtaining funds for institutions and properly trained personnel.10

Speranza's 1901 article, however, had to do not so much with penology as with a related matter: legal insanity. The principles of the new science applied to one as they applied to the other, but the two matters differed in what proved to be important ways. For law,

8. Dayio J. Rothman, Conscience and Convenience: The Asylum and its AlterNATIVES IN PROGRESSIVe AMERICA 50 (1980). For a more general discussion, see id. at 4381. Rothman does not venture the precise supposition I have made in my generalizing account. See also Haney, supra note 6 . Haney would, I believe, apply a version of this perspective to many of the new scientists as well.

9. See ALLEN, supra note 6, at 32-59.

10. See generally ROTHMAN, supra note 8 (discussing the political dynamics behind the rise of the treatment ideal). 
for lawyers, and for the public at large, the science of human behavior posed far greater problems with regard to the insanity defense than with regard to the punishment - I should say, the treatment and cure - of convicts, even though the insanity defense involved far fewer persons. Why should this have been so?

It is important to understand that in American jurisprudence indeed, in Western jurisprudence generally - a fundamental bifurcation had long been emerging between the trial and punishment stages of criminal administration. Progressive-Era penology was to further this split, though the degree to which it did so remains one of the great gaps in our knowledge of criminal justice administration. The phenomenon of bifurcation is a central feature of the approach we take to the criminal law, one of those developments that tell us a great deal about who we are, or what we seek to be. The tendencies of mind it reflects are general to our jurisprudence, not special to the criminal law.

At the level of theory, the bifurcation of criminal process reflected the differing ways in which jurists and behavioral scientists conceptualized criminal responsibility. Despite determinism's inroads, at the trial stage the traditional concept of guilt retained in intent-based crimes - most of its force, mens rea premised upon free will. The defendant might have been buffeted by forces over which he possessed little or no control, but he had - so the theory ran - retained sufficient determination over his behavior to be thought of as having acted freely. This idea, with which we are all familiar, was expressed in various ways in the late nineteenth century. In his influential Treatise on Criminal Law, Francis Wharton put this pact with the angels as follows:

To responsibility (imputability) there are, we must remember, two constituents: (1) capacity of intellectual discrimination; and (2) freedom of will. If there be either incapacity to distinguish between right and wrong as to the particular act, or delusion as to the act, or inability to do or refrain from doing the act, then there is no responsibility. The difficulty is practical. No matter what may be our speculative view as to the existence of conscience, or of freedom of action, we are obliged, when we determine responsibility, to affirm both. ${ }^{1}$

[Footnote 1: The controversy which divides theologians as well as metaphysicians as to the freedom of the will is not involved in the discussion in the text. It may be possible that, from a high metaphysical point of vision, all acts are necessitated. With this, however, jurisprudence, which is a practical science, has nothing to do. There have been indeed leading jurists, such as Feuerbach, who have adopted the principle of necessity, and have invoked the fear of punishment as a counter-weight to the temptation to crime.... But this, as is well said 
by a leading German author ... takes not only from jurisprudence, but from life, its moral dignity, making the former a mere marshalling of mechanisms, and the latter, a mere mechanism of necessities.] ${ }^{11}$

As applied at trial, the concept of mens rea typically reflected traditional ideas, long after those ideas had begun to give ground at the post-trial stage. The conservatism inherent in the legal definition of criminal responsibility presents itself clearly: one has only to consider the narrowness of the two legal categories that constituted the main defenses of unfreedom - duress and insanity. Duress required a threat, or reasonable belief in the threat, of direct and dire physical harm - a gun-to-the-head example would overstate the case, but not by much. ${ }^{12}$ Legal insanity generally required lack of knowledge of what one was doing, or of the fact that it was wrong, though by Speranza's time, a fair number of states allowed recourse, under some circumstances, to the so-called irresistible impulse test. The classic formulation of that test required a causal nexus between a preexisting mental disease and the suspension of the defendant's control over his behavior. ${ }^{13}$ Long-standing diseases of the brain that did not obliterate one's cognitive capacities or result in severe delusion or destroy self-control did not meet these tests; nor did many other mental states that medical scientists generally classified as insanity in the context of civil commitment. If prevailing rules regarding legal insanity typically excluded the kleptomaniac, a fortiori they excluded the great mass of defendants who had been indicted for property offenses and whose only claims in

11. 1 Francts Wharton, A Treatise on Crmminal Law 51-53 (8th ed. 1880). This formulation was retained in the 9th edition (1885) at Vol. 1, page 53; the 10th edition (1896) at Vol. 1, page 49; the 11th edition (1912) at Vol. 1, page 65; the 12th edition (1932) at Vol. 1, page 70. An editorial note in the American Law Review put the matter rather differently:

In the most general sense, no man can refrain from doing what he does. In an absolute sense, no man is a free moral agent, any more than a grain of sand which drifts in the wind is a free moral agent; but every act which a man does is, when done, the result of a series of causes which have existed throughout all time. When men get sense enough to understand this, then the right to punish crime will rest upon a different ground from that upon which it is now placed.... The sheet-anchor in this conflict of opinion is this: the foundation of will is intelligence, - knowledge, or the power to know; when that is possessed, the law must conclusively presume that the power of self-restraint exists along with it, and must act and punish upon this assumption.

19 AM. L. Rev. 765 (1885).

12. 1 WhaRTon, supra note 11 , (8th ed. 1880) at 130; see also 1 id., (10th ed. 1896) at 117. For the contemporary English rule, see SIR JAMES FITZJAMES STEPFEN, A GENERAL View OF the Criminal LAW OF ENGLAND 69-70 (2d ed. 1890). Stephen describes the rule as "narrowly limited and somewhat capricious." Id. at 69 . He states that it does not cover a murder defendant who shows that his own life was threatened if he did not commit the act, for if it did: "Criminals might commit offences with impunity by threatening others." $\mathrm{He}$ noted, however, that "the fact of compulsion may always be taken into account in reduction of punishment." Id. at 70.

13. Parsons v. State, 2 So. 854 (Ala. 1887). On the law of insanity at the end of the nineteenth century, see 1 WhARTON, supra note 11, at $49-73$ (10th ed. 1896). 
mitigation - had they been allowed to make them - would have been based on poverty, lack of education, the influence of evil associates, or other essentially social circumstances.

The criminal trial represented a first stage in the criminal process at which the law, reflecting general social mores, insisted upon the existence of free will; this stage, wherein guilt or innocence was assessed, was, as always, a morality play that confirmed our deepest longings about who we are as human beings. The trial took this construction despite the fact that those found guilty were immediately turned over to a sentencing process wherein they were often viewed largely (by no means entirely) as victims of biological or social circumstances. At this second, "individualized" stage of the criminal process (at least according to the ideal) information about the convicted defendant's background, upbringing, associates, and so on - matters rarely formally admissible during the trial - became relevant. Progressive-Era penology aspired to the creation of a large bureaucracy dedicated to gathering, sifting, and analyzing such data and to a bench prepared to pass judgment regarding sentence case-by-case on the basis of that information. ${ }^{14}$. Juries, aided

14. RoTHMAN, supra note 8, at 43-81. Rothman's account reports contemporary ideals rather more than actual practices.

One leading criminologist of the 1930s both criticized the half-hearted application of the new penology and commented sardonically upon what I have termed the "bifurcation" of trial and sentencing:

And so we witness the strange spectacle of a defendant being indicted and tried for a specific offense, the only issue being whether or not the crime was committed, for which the legislative prescribes a definite punishment, and a history of the background of the offender furnished by the probation department which is generally irrelevant and may not be introduced at the trial. The stark inconsistency in spirit between the criminal law seeking to punish for guilt and the administrative device of probation seeking rehabilitation of the offender is blurred by slipping the probation report to the judge before sentence is imposed.

Nathaniel Cantor, Conflicts in Penal Theory and Practice, 26 J. CRIM. L. \& Criminology [hereinafter J.C.L.C.] 330, 334 (1935). I referred to the phenomenon of bifurcation at the close of my study of the English criminal trial jury. See THOMAs ANDREw GREEN, Verdict According to Conscience: Perspectives on the English Crmminal Trial Jury, 1200 1800 , at 383 (1985). Others have noted the same or an analogous phenomenon. See, e.g., David Garland, Punishment and Welfare: A History of Penal Strategies 190 (1985) (contrasting 'judicial' and 'administrative' processes in early-twentieth-century Britain); Alan Norrie, Crime, Reason and History: a Critical Introduction to CrimiNAL LAW 46 (1993) (contrasting trial and subsequent mitigation of sentence in English practice). Norrie states:

The possibility of mitigation of sentence is a marvelous mechanism for allowing the criminal process to "have its cake and eat it." Having convicted the accused by a strict, unbending set of rules, the rule books are cleared away and judicial or governmental discretion comes in to do "real" justice to the individual, or to temper legal justice with mercy.

Id. Another example can be found in F.A. WhrtLock, Crmminal Responsmilliry and MeNTAL ILLNEss 71 (1963) ("It is, perhaps, in the realm of penology that the law is most apt to fall back on determinist principles whereas the psychiatrist, with his concern for the individual, is most likely to try by his own special methods to get the offender to accept the responsibilities of the adult."). 
by clever lawyers or the defendant's "demeanor," often drew their own inferences regarding such matters, achieving a kind of "individualization" that leavened the law and tracked the new penology in a rough-and-ready fashion - serving unselfconsciously, one might say, to mediate the conflicting paradigms of criminal justice. Nonetheless, the point remains: The law of evidence regarding guilt or innocence reflected one concept of human behavior; the new penology - ideas about the appropriate treatment of offenders who have run the gauntlet of our blaming instincts and have satisfied our need that they carry the stigma of criminal guilt - reflected quite another. Perhaps we should not be surprised: The paradox exists today, though a relatively small percentage of criminal defendants opt for jury trial and though we now retain little of our earlier faith in our capacities to cure convicts of the ills with which society has endowed them.

If the law held fast against the onslaught of the new sciences, it is nonetheless true that some jurists were troubled by peremptory rejection of the new learning. Even Wharton's formulation may be said to reflect underlying tensions; such inherently practical stances must have occasioned tensions in all but the most orthodox. Wharton himself was something of a pioneer among jurists on the question of the insanity defense, though his views in this regard were kept contained by his strong resolve to draw the line against signifcant erosion of the concept of criminal responsibility. ${ }^{15}$

The complex juristic reaction to the intellectual currents of the late nineteenth century, which has thus far received little scholarly attention, can be witnessed in microcosm in a three-part article that appeared in the Criminal Law Magazine in 1893. Here Omer Hershey, a practicing lawyer, addressed the subject of "Criminal Anthropology."16 Hershey's response to the new learning was, overall, sympathetic, but presaging themes in both Speranza and Pound, he criticized the overreach of some of its practitioners and concluded that, in any case, its practical application to criminal responsibility remained a matter for the future. ${ }^{17}$ More striking is Hershey's ob-

15. See Janet A. Tighe, Francis Wharton and the Nineteenth-Century Insanity Defense: The Origins of a Reform Tradition, 27 AM. J. LEGAL Hist. 223 (1983).

16. O.F. Hershey, Criminal Anthropology (pts. 1-3), 15 CRIM. L. MAG. \& REP. 499, 658, 778 (1893).

17. Id. at 778 .

It may well be doubted, however, whether criminal law, with all its shortcomings, has much to hope from this new science which has come in with such a flourish of trumpets and such an array of "newly-discovered" natural facts. Criminologists are loud in criticism that is destructive, but silent as to much that is constructive. They offer few reforms bearing on criminal law as a science or juridical system, and those offered frequently rest 
servation that the new science had much to contribute to current penal practice, if not to the concept of guilt: it exemplifies what I have called the tendency toward "bifurcation."18

More striking still is Hershey's assertion that "[a] man without any intention to commit a crime, may, nevertheless, have the criminal intent, the mens rea, necessary to make his act a crime. Criminal intent is determined from acts alone and not from any psychologic tests."19 If the legally insane are not punished, Hershey claimed, it is "because they have no mens at all."20 In Hershey's view, the "penological criterion" of the criminal law was "social necessity; its measure of justice the safety of society."21 Thus, he stated, "Crime may be organic, but the only definite meaning a lawyer or legislator can attach to it, is that it is an act or omission punishable by law."22 A few others fended off the scientists' charge of irrationality by denying the relevance of retribution and stressing instead the purely utilitarian side of criminal justice as a social defense, 23 which had long been one element in classical criminal jurisprudence. But few invoked Hershey's theory of the core meaning of mens rea when they addressed serious, intent-based harms - for example, most forms of homicide, assault, or theft - the offenses

on bias and misconception. They fail to recognize the difference between a purely scientific treatment of crime and the practical treatment which it must receive under the law. Science and law cannot afford to be hostile, but neither can they hope to move arm in arm. Science moves rapidly; its mistakes are easily corrected and its consequences are remote. Not so law. It changes slowly and carries immediate responsibility. It must be certain, and, therefore, more or less arbitrary.

Id.

\section{Id. at 783-84.}

If criminal anthropology is not likely to have much influence on the great body of criminal jurisprudence, its value in the larger question of crime and criminals cannot be over-estimated. Crime can best be combated by discovering and removing its causes. In the penal reforms like those just mentioned the great practical value of the new science is supposed to lie in its ability to discriminate between criminal and criminal and to apply to each individual case its proper treatment. An anthropological examination is to determine the status of the criminal, his proper treatment and the time and conditions of his liberation. If the science can do this, criminal law has no fault to find. Whether it can do more, time will show.

Id.

19. Id. at 780 .

20. Id.

21. Id. at 779.

22. Id. at 778.

23. See, e.g., Charles Dudley Wamer, Some Aspects of the Indeterminate Sentence, 8 YALE I.J. 219, 220 (1899) ("[N]o human discretion is adequate to mete out just punishment for crimes; and it has come to be admitted generally, by men enlightened on this subject, that the real basis for dealing with the criminal rests, firstly upon the right of society to secure itself against the attacks of the vicious, and secondly upon the duty imposed upon society to reform the criminal if that is possible."). 
to which criminal anthropology primarily directed its attention. ${ }^{24}$ Despite the fact that punishment-as-deterrence might well imply a deterministic understanding of human psychology, one suspects that most late-nineteenth-century, deterrence-oriented social defense jurists would have rejected a strong theory of determinism, which they probably viewed as, at best, no more verifiable than "free will," and defended the law's underlying "presumption" of human freedom.

In truth, we do not yet know what most jurists thought regarding all of the questions Hershey had raised. The legal profession as a whole may well have mirrored society at large, translating the presumption of free will regarding responsibility into the justification of retribution regarding punishment. (That is what the new scientists charged and what, quite evidently, some of the leading Progressive legal academics came to believe.) To be sure, some judges, law-trained penologists, and legal academics reflected varying levels and aspects of the "scientific" perspective. By the time Hershey wrote, cracks had appeared - and at some points widened - in the legal monolith. The faults in the conventional bedrock legal presumption of human freedom were no doubt a matter of common knowledge in juristic circles. Yet, then as now, wisdom counseled against head-on confrontation: witness Holmes's circumlocutions of the preceding decade. ${ }^{25}$ Sometimes wisdom even counseled an

24. Hershey himself cited a recent article on mens rea which stated that mens rea "applies only to persons legally capable of ... acting voluntarily," and that

[s]ilence as to intent in the statutory definition of a crime, is itself to be construed as an exclusion of it as an element of the crime, in enactments whose purpose is the establishment and enforcement of police and sanitary regulations for the safety, moral and physi$\mathrm{cal}$, of the public at large, provided that the purposes to be accomplished bear a reasonable proportion to the penalties that may be inflicted upon innocent persons.

G.A. Endlich, The Doctrine of Mens Rea, 13 CRIM. L. MAG. 831, 844 (1891). For a discussion of competing approaches to the role and meaning of mens rea in the Anglo-American tradition, see Gerald Leonard, Public Wrong and Vicious Will in Nineteenth-Century Statutory Rape Law: The Evolution of the Mental Element in the Age of the Codification of Criminal Law (unpublished paper on file with author).

25. Oliver Wendell Holmes, The Common Law (Mark DeWolfe Howe ed., 1963) (1881). I read Holmes as skeptical about human autonomy, as recognizing (with some diffdence) the widespread notion of relative degrees of freedom, as when he suggests that: "If punishment stood on the moral grounds which are proposed for it, the first thing to be considered would be those limitations in the capacity for choosing rightly which arise from abnormal instincts, want of education, lack of intelligence, and all the other defects which are most marked in the criminal classes." Id. at 38. But there is support for reading Holmes's apparent allusions to the true freedom of some persons as mere lip service in a still earlier passage: "The desire for vengeance imports an opinion that its object is actually and personally to blame. It takes an internal standard not an objective or external one, and condemns its victim by that. The question is whether such a standard is still accepted either in this primitive form, or in some more refined development, as is commonly supposed, and as seems not impossible, considering the relative slowness with which the criminal law has improved." Id. at 35. For an important related discussion of Holmes, see RICHARD A. POSNER, 
exaggerated insistence upon true orthodoxy: To take the most obvious example, law tended to follow general social perspectives on freedom of the will in the context of the trial of the assassin Guiteau. ${ }^{26}$

From this remove, it is difficult to tell just how completely polarized the worlds of law and science were in the last decades of the century. What we can discern in at least a general way is that in Speranza's day - at the fin de siècle - some medical and behavioral scientists were greatly agitated about what they deemed to be the atavism of the law. In their view, Americans hewed to an outdated notion of human behavior, premised criminal law on a false concept of guilt, and based punishment on primitive feelings of revenge. Although the scientists may have thought that these mistaken tendencies were slowly giving way - especially with regard to penology - they probably perceived that there was little likelihood that the concept of mens rea would itself be reformed. For many medical scientists, this posed a special problem: as expert witnesses in insanity cases, they were confronted with legal definitions that did not match medical conceptions of human behavior. ${ }^{27}$ But for all of these new scientists, the problem was essentially the same. Criminal guilt assumed free will, and for the scientist - who was trained to ascertain the causes of mental states and acts - that concept of criminal responsibility was, at best, problematic. Why distinguish among causes; why deem only some symptoms relevant? What was - in a world of causes and effects - "free" agency? Speranza's article was meant - in this heated atmosphere - to console, to induce patience and understanding. His words - at greater length than I have as yet given them - were as follows:

There is one barrier, however, that appears insurmountable, as to which, while it stands, law and medicine may declare a truce, but can agree to no terms of peace; I refer to that most ancient and greatest of questions - the freedom of the will.

The study of man from the physiologic standpoint has an undoubted tendency to make him, in the eyes of his investigator, a crea-

The Problems of Jurisprudence 168-69 (1990). See also Martha C. Nussbaum, Equity and Mercy, 22 PHIL. \& PuB. AfF. 83, 111-15 (1993).

26. See ROSENBERG, supra note 6.

27. Tighe, supra note 6 , at 203-26, 234-92. In the first three chapters of her dissertation Tighe ably relates the debate over insanity (and its relationship to the free-will issue) from the middle of the nineteenth century until the last decade or so of the century. See also JAMES C. MOHR, DOCTORS AND THE LAW: MEDICAL JURISPRUdENCE IN NINETEENTH-CenTURY AMERICA 176-79, 197-212, 234-36 (1993); ROSENBERG, supra note 6, at 66-70; Hovenkamp, supra note 6. 
ture of forces beyond its control. Man in this aspect ceases to be a free agent in the eyes of the student....

... It will hardly be denied that the tendency of psycho-physical study of man must be towards a denial of spirit.

Law, on the other hand, stands pre-eminently for the freedom of the will. Without this as a foundation-stone juridic science has no existence, for the very test of juridic responsibility is man's power of choice. To this the juridic philosopher brings the sentiment of humanity, the teachings of metaphysics and the experience of history, which are repugnant to the physical measurement of the soul; he contends that after you have taken man's brains to pieces you have not yet found his mind; that molecular interaction may be demonstrated as the physical counterpart of thought, but it is not thought. ...

I am not taking sides on this question: I am endeavoring to present the position of each party and its sources of strength. Unless we recognize this no fair judgment can be made. This is an age of specialization, and the curse of specialization is that it distorts proportions and narrows the horizon in mental life.

Medicine is essentially a positive science: it is based on the observation of physical phenomena. Law is one of the humanities: it is [in Holmes's words] the "witness and external deposit of our moral life. Its history is the history of the moral development of the race." The doctor and the jurist too often forget the many-sidedness of man. The mental pathologist is dazzled by the discoveries regarding the physical basis of mind and his mental equation thereupon blinds his judgment. On the other hand, lawyers make too much use of logic, forgetting that [Holmes again] the "life of the law has not been logic, but experience." ...

Can these opposing forces be turned into a common stream of usefulness? Can this medico-legal conflict be brought to a settlement which will be neither a mere working truce nor a concession to eclecticism, but an agreement based on reason and scientific data?

$\cdots$

... [I]t will be one step towards an agreement, if law and medicine will become mutually more tolerant, and will give to their opponents' views serious and impartial study.

The language of Dr. Carlos F. Macdonald is none too strong when he tells lawyers that "to set up a legal test or standard of insanity which is not in harmony with the teachings of medical science ... is a disgrace to jurisprudence and a travesty upon justice." (American Journal of Insanity, Vol. LVI., 1899.) On the other hand, doctors would do well to ponder over Mr. [Edward] Payson's words when he says that law by its conservatism has "shunned many a quagmire, detected many a false light and stood fast against many an onslaught of ism and ology on the road of human progress."

Let neither the doctors nor the lawyers draw an impassable and inflexible line around their respective fields of investigation, but let them work in common for a common end. No mere doctor, and no mere lawyer, will be the one master that will solve the problem of 
mental responsibility in law .... The Great Pacificator in this medico-legal conflict will be he who ... will serenely and persistently strive for the study of man as he is in his many aspects ... it will be he, who, knowing the dangers and impracticability of endeavoring to solve human problems by adhering to theories and ideals, is nevertheless confident that without theories and ideals the hope and certainty of progress are idle and vain boasts. ${ }^{28}$

Are you consoled? Was Speranza? These are noble thoughts elegantly stated, but that should not deter us from asking: Was Speranza being sincere? At first blush, we may harbor doubts. There is perhaps too much poetry and too little rock-hard meaning in Speranza's plea for reconciliation, tolerance, and cooperation. What do we know about Speranza? What light can we shed on his MedicoLegal Conflict article from an examination of his other writings?

Speranza was born in Connecticut in 1872, the son of Italian immigrants. His father taught Italian literature at Columbia but frequently took the family back to Verona where Gino began school, gained fluency in Italian, and became imbued with a sense of his heritage. Returning to America in 1881, he undertook his undergraduate studies at City College and his legal education at New York University. Speranza's legal career was probably partly defined by his Italian childhood and identification. Within three years of his graduation from law school in 1894, Speranza became legal counsel to the Italian consulate general in New York. Soon after, he began to devote much of his time and energy to the burgeoning Italian immigrant community, specifically to the legal problems of the immigrants. Speranza's early embrace of Italian distinctiveness and cultural pluralism gave way, perhaps even before World War I, to espousal of thoroughgoing assimilation. His early writings dealt mainly with criminal jurisprudence and penology, his later work with crime and immigration and, finally - in what has been described as an act of "self-denial" - with the virtues of Americanization. ${ }^{29}$

28. Speranza, supra note 5, at 125-26 (citation omitted). Speranza's reference to Payson's work refers to EDWARD PAYSON, SUgGestions TOWARDS AN APpLIED SCIENCE OF SOcIOLOGY 176 (1898), and Speranza's phrase, "The Great Pacificator," was, of course, derived from the popular reference to the Antebellum master of political compromise, Henry Clay.

29. Louis C. Anthes, Race or Nation: An Italian-American's Critique of Immigration (Sept. 28, 1994) (unpublished manuscript, on file with the author). Anthes focuses on the roots and maturation of Speranza's views regarding Americanization. Anthes uses the term "self-denial" at page 27. For details regarding Speranza's early life, see id. at 3-4. I am grateful to Mr. Anthes for allowing me to cite his unpublished essay. See also Arthur Livingston, Gino Speranza: The Evolution of An American, in 1 The DIARY of Gino SpERanza. ix, ix-xxvii (Florence Colgate Speranza ed., 1941); George E. Pozzetta, Gino C. Speranza: Reform and the Immigrant, in REFORM AND REFORMERS IN THE PROGRessive ERA 47 (David R. Colburn \& George E. Pozzetta eds., 1983). 
Although Speranza was trained as a lawyer in the United States, he seems to have absorbed in his earlier years a substantial background in continental history and political thought. At some point - perhaps while in law school - he read and was influenced by continental legal ideas, especially the new criminal anthropology and jurisprudence. From these sources he developed a behavioral science perspective, an impatience with the Anglo-American approach to jurisprudence generally and to criminal justice in particular. That impatience - better to call it hostility - is reflected in his earliest writings, occasional pieces on the Italian penal code of 1888 , penology, and the relationship between the principles of science and those of the common-law tradition.

The young Speranza, then, was something of an anomaly: an American lawyer with a continental background and a powerful continental jurisprudential disposition. In common with many fin de siècle American lawyers, he saw penal reform as not only a legal, but a social and political movement of great importance. But as we shall see, Speranza's perspective carried him far beyond the point to which most American jurists were inclined to go in the direction of the new sciences. He became, as I see him, mainly an outsider, a lawyer in league with behavioral scientists and, to a significant degree, at war with his own American profession. The 1901 article called for a truce. But, again, on what terms? We shall assess the nature of the campaigns that preceded and followed it.

Two of Speranza's earlier writings - one from 1899, one from 1900 - are of special interest in relation to the later piece. The first and the more scholarly of the two was a paper read before the Society of Medical Jurisprudence, entitled "Natural Law Versus Statutory Law."30 By "Natural Law" Speranza meant the laws of nature that are discoverable through scientific observation and analysis - not the more traditional natural law of religion and philosophy that for centuries had been defined as the moral laws designed by God and knowable to man through God-given powers of reason. By "Statutory Law" Speranza meant the principles of juridical, as opposed to natural, science - historically based and time-tested principles that had either been embedded in statute or retained force as nonstatutory common law. These juridical principles had been received and elaborated upon by jurists and legisla-

30. Gino C. Speranza, Natural Law Versus Statutory Law, 59 ALB. L.J. 400 (1899). Speranza drew his title from language - quoted in his article at $404-$ used by F.H. Wines. See Frederick Howard Wines, PUNISHMENT AND REFormation: AN HISTORICAL Sketch of the Rise of the PENITENTIARy System 263-64 (1895). 
tors. In the process, some of the discoveries of natural science had accounted for incremental changes, but in the main, Speranza seems to have believed, legal science remained traditional and precedent-based: Natural science had been assimilated by juridical science only to the extent that it could be made to conform to the precepts of juridical science.

Speranza's attack on juridical science was unrelenting: "Venerability is its pride, stare decisis its demigod. It is conservative almost to the point of stagnation." 31 It bases

its decisions on antiquated and discarded theories ... finding justice not so much in the appreciation of facts in a new and modern light, but in the decisions of judges, dead or living, whose claim to authority at times arises from the fortuitous circumstance of having occupied the bench of the highest tribunal of the land! 32

The contrast between juridical and natural science was, therefore, stark: "The charlatans of the Middle Ages and the quacks of more recent times were oftentimes honest men, and, measured by the ignorance of their surroundings, they may even be called learned men. Yet do our modern physicians follow their prescriptions?"33 I trust I need not continue in this vein.

Speranza's critique turned in the direction of a fairly conventional plea for an utterly positivist approach to criminology and penology. ${ }^{34}$ His claim that "our classic jurisprudence has studied the crime and practically failed to study the criminal" can be found in numerous contemporary works. ${ }^{35}$ His optimism and his confidence in the new sciences of the day were nearly unbounded, as were those of his audience, the members of the Society of Medical Jurisprudence. Even his cautionary remarks about those scientists who, caught up in one or another fashionable new theory, allowed their "convictions to blind [their] judgment" 36 had been sounded frequently in scientific circles. Speranza's target - a quite common one - was Lombroso, whose criminal anthropology carried over

31. Speranza, supra note 30 , at 400 .

32. Id. at 401 .

33. Id.

34. Speranza claimed: "I am not here to defend [the "Positive School's"] theories or to attack its critics, but merely to state its method of research and to describe its field of activity." Id. at 402 . He quickly dropped this pretense of neutrality.

35. Id. at 401. See also Henry M. BoIes, The Science of Penology: The Defense of Soctety Against Crime 90-92 (1901); Willtam Douglas Morrison, Crime aNd ITs Causes, at v-x (London, Swan, Sonnenschein 1891); Maurice Parmelee, The Pranciples of ANthropology and Soctology in Their Relations to Criminal Procedure 14-20 (1908).

36. Speranza, supra note 30 , at 403 . 
elements of the earlier "science" of phrenology, including a variant upon the notion that one could determine personality traits, including criminal tendencies, by studying the shape of a person's head. ${ }^{37}$ But Speranza struck a more original note than most other critics in his treatment of the legal profession's "bias against innovations":

"If you touch our courts," cry the lawyers, "you will destroy the bulwarks of our liberties; if you change our laws you will endanger our most cherished principles!" But these are not arguments; they are the repetition of those wails of despair which well-meaning but narrow-minded men raised during the so-called conflict between science and religion. 38

The "wails," the appeals to "the bulwarks of our liberties," were simply not to be taken seriously.

Nor would they be. The "Positive School of Criminal Jurisprudence" would carry the day.

Justice . . . is truth, absolute truth. ...

... The conflict between science and jurisprudence, between natural law and statute law, is unavoidable and irrepressible. ...

$\cdots$

... [I]t requires no prophetic power to predict that such conflict will have but one radical though salutary result - it will establish the fact that it is Truth and not the King that can do no wrong, thus substituting an axiom for an assumption as the cornerstone of juridic science.

Science has destroyed empires of venerable theories . . . let us hope that the kingdom of scientific law is at hand! ${ }^{39}$

This does not sound like the consoling counsel of compromise that Speranza wrote for the benefit of a mainly legal audience two years later. But, then, the later paper had in fact envisioned a near-total victory on the part of science. Only the one, irreducible problem of free will could never truly be solved - save by mutual agreement not to agree - and there is no sign that Speranza had seen this

37. For a lengthy discussion of Lombroso, see Hershey, supra note 16, at 500-04, 658-61. Hershey concludes, inter alia: "It may be added that even admitting that the criminal has abnormal physical peculiarities, Lombroso goes much too far in concluding that these constitute him a type." Id. at 661.

38. Speranza, supra note 30 , at 401.

39. Id. at 403-04. Speranza understood that science still had a long way to go: "Criminology is still in its infancy ...." Id. at 403. In an earlier article, Speranza had expressed some doubt about the practical application of science to law. Commenting on the Italian Penal Code's test of responsibility, Speranza stated: "The test is, of course, far from perfect, far from precise. It is doubtful, indeed, if legislators will ever be able to formulate a satisfactory definition of this difficult question. Scientific definitions of criminal responsibility have been too technical or abstruse to be of much practical use, and yet the question is eminently a scientific one." Gino C. Speranza, Criminal Responsibility under Italian Law, 55 ALB. L.J. 411, 414 (1897). 
point before 1901. It was as though the scientist-lawyer, in 1901, stood before his legal colleagues, much chastened by new insight, and appealed over their heads to the scientists to join him in his campaign to make peace with the juristic tradition. What was the source of this insight that brought Speranza to his Canossa?

Not long after he addressed the Society of Medical Jurisprudence in April, 1899, Speranza published an article in the February, 1900, issue of Popular Science Monthly, in which he addressed an educated public on "The Decline of Criminal Jurisprudence in America."40 Speranza's subject was not simply the conflict between law and science, but the difference between the continental, or "Latin," approach to criminal jurisprudence and that of England and America, the "Anglo-Saxon" approach. From the perspective of the turn of the century, it appeared to Speranza that, however good the eventual prospects of the new science might be, the great advances in criminal jurisprudence of the Italian and French schools of the preceding decades were losing the influence they had attained in Anglo-American circles at the time of their first appearance. In reality, the story was not so much one of decline as of a failure of the new science to take hold after a promising debut.

Speranza's article reflected disappointment as well as criticism, but it reflected, too, a grudging appreciation of the Anglo-Saxons' great contributions to law and justice. The readers of Popular Science Monthly were no doubt pleased to hear at the outset that "[t]he rights of personal security, personal liberty, and private property have been called the 'rights of the people of England," and "[w]hile, in a certain sense, they belong to all civilized people, yet, in their practical application, they are peculiarly the creation of Anglo-Saxon common sense and love of order."41 Speranza pointed out that on the Continent the attempt to vindicate these rights - "clothed by the Latins in the seductive garb of Liberté, Egalité, Fraternité" - "gave us a Reign of Terror, a Commune, and finally a doubtful republicanism," while the Anglo-Saxons, employing "the less dazzling formula, "That no man shall be deprived of life, liberty, or property without due process of law,' " achieved "more enduring democracies 'of the people, by the people, and for the people." "42 The Anglo-Saxons found in courts of law "the highest safeguard for their ancient rights" against the threats posed by a

40. Gino C. Speranza, The Decline of Criminal Jurisprudence in America, 56 PoPULAR ScI. MONTHLY 466 (1900).

41. Id. at 466.

42. Id. 
"partisan Legislature and a tyrannical Executive."43 It was natural, then, "that it has become a belief, having the force of faith, that in our courts will be found the bulwark of those liberties which we consider essential to the full enjoyment of life." 44 We may wonder how many of Speranza's readers had read his address to the Society of Medical Jurisprudence, which had just been reprinted in the pages of the Albany Law Journal, 45 where the author mocked the notion of judicial bulwarks of liberty as a fraudulent excuse for not embracing a more properly scientific approach to the law.

To be sure, as in the earlier paper, Speranza criticized AngloSaxon justice as too slow to put law on a scientific footing. He issued a report card on Americans' progress in basing the criminal law - the branch of law on which "we must rely for the enunciation of what acts shall constitute a breach of the right of life, liberty, and property" 46 - on the "highest dictates of human knowledge:"47 Our record, Speranza confided to his readers, was poor. Law schools, for example, devoted little time to the teaching of criminal law; faculty members who taught the subject did not specialize in it - for example, the professor who taught criminal law at Michigan, Speranza reported, also taught bills and notes. Both young lawyers and the community at large were cynical about criminal courts, criminal defendants, and the criminal bar. On the Continent, "where less boast is made of inalienable rights," the situation was the reverse: "[I]t is the ambition of all lawyers to get a reputation at the criminal bar."48 The Anglo-Saxons - and here Speranza meant mainly Americans - were failing in their duty to safeguard the fundamental rights for which they were famous. It was a gentle and respectful but thorough scolding.

43. Id.

44. Id.

45. Speranza, supra note 30.

46. Speranza, supra note 40 , at 467.

47. Id. at 466.

48. Id. at 469. Compare O.F. Hershey's statement:

In England and America there seems to be a natural antagonism between the medical and scientific on the one hand, and the legal or judicial on the other. It is different on the continent. There some of the staunchest advocates of the value of medico-legal and scientific investigations are prominent lawyers and judges. The first ambition of the new science is to overcome this antagonism. It has no ambition to do away with law. The study of criminology and medical jurisprudence is to be introduced in law schools, and is to be made one of the requirements of admission to criminal practice. A special training on the subject is to be required of magistrates and judges. They are to study law books less and criminals more. They are to be more than merely jurists.

Hershey, supra note 16 , at 780-81 (citation omitted). 
The transition from Speranza's Society of Medical Jurisprudence address to his 1901 article in The Green Bag was well under way by the time he wrote the intermediate Popular Science article. No doubt, the intended audience had something to do with the changed tone and perspective. But the conclusion seems irresistible: Speranza was - perhaps due to a rethinking occasioned by the forum for which he wrote - taking the Anglo-American rightsoriented tradition more seriously. There were costs to society from hide-bound adherence to tradition; but that adherence had, after all, prevented sudden radical innovations that might have concentrated too much power in a single person or in an institution beholden to popular passions of the day. Conservatism and basic freedom had, roughly speaking, been blood brothers in the AngloSaxon tradition. The problem was, as Speranza now saw it, that the Anglo-Saxons were in danger of sacrificing all they had achieved on the altar of mindless traditionalism. Some sensible accommodation between modern science and traditional rights must therefore be reached, especially in criminology. Speranza noted that under the prevailing American system of criminal justice, many defendants were sentenced to prison who ought to have received psychiatric treatment under conditions of civil commitment, and many others who were acquitted on "technicalities" that "save scoundrels" ought to have gone to prison. ${ }^{49}$ The more rational system of the Continent, where the new sciences were respected within legal circles, was a guide to be followed. But, Speranza seems to be saying, its lessons in tyranny should not thereby be overlooked.

Thus, we ought to take seriously the concluding, pious invocations of the Anglo-Saxon tradition in Speranza's 1901 paper. Let me recall his words, or those of Edward Payson, whom he quoted. Law, Payson wrote, with respect to the Anglo-American tradition, had "shunned many a quagmire, detected many a false light and stood fast against an onslaught of ism and ology on the road of human progress." 50 Speranza had, evidently, been much influenced - converted, perhaps? - by Payson, whose recent book incidentally and half-heartedly sounded a theme that helped to explain, and justify, the cautious approach to continental science taken by the American legal profession. ${ }^{51}$ Speranza, himself, was, of course, cautious in his approach to this emerging rationalization of the American legal profession's perspective; he balanced it, you may

49. Speranza, supra note 40 , at 472 .

50. Speranza, supra note 5, at 126.

51. PAYson, supra note 28. 
recall, against the injunction that " to set up a legal test or standard of insanity which is not in harmony with the teachings of medical science . . . is a disgrace to jurisprudence and a travesty upon justice." "52 In this caution and balancing Speranza sought a middling, best-of-both-worlds position, one that both accorded the realities of nature their due and respected the deepest yearnings for human freedom. Irrational treatment of criminal defendants he would not abide; yet, in the service of liberty, the concept of free will ought to retain a place at the core of the legal - not the scientific - conception of human behavior. 53

Although we may conclude that Speranza's consoling compromise was sincerely meant, we must also recognize that it was more wishful thinking than a practicable or coherent program. Where would one draw the line between the reforms that science demanded in the defense of fundamental rights and those repugnant to the concept of human freedom, also crucial to the defense of those rights? For all one could say, the American system of criminal justice already drew the appropriate line: Any reform of the seeming irrationality of criminal justice, one might maintain, could have begun an irreversible movement toward an undermining of the concept of freedom. Who can ever say whether we paid a higher cost for our concept of freedom than the marketplace of human ideas actually required?

From the perspective of history, we can draw some conclusions. We know that the movement of which Speranza was a part fed into a larger, more politically based, movement for the reform of American institutions, including those of criminal justice. Indeed, as of 1901, the reform of Progressive-era penology was already under way. As it turned out, there was room for change, even dramatic

52. Speranza, supra note 5, at 126 (quoting Dr. Carlos F. Macdonald).

53. Not all lawyers who were intrigued by the new sciences ultimately compromised on the free-will issue with regard to the guilt-assessment stage. Two legal writers recommended that the jury determine solely whether the defendant committed the "act" with which he had been charged. Charles Curry would then have a group of experts classify the defendant "as a mad, born, habitual or occasional criminal, or a criminal of passion, and then the court should sentence him for an indefinite time, or suspend his sentence according to the nature of the case, and the history, condition and character of the offender." Charles Curry, Criminals and Their Treatment, 36 AM. L. REv. 10, 22 (1902). Ethan Dausman would then have the jury answer a second question: whether or not the defendant could "be safely permitted to remain at liberty without injury to the welfare of society." If the jury found that the defendant could not be safely released, the court would sentence him for an indefinite period. Ethan $A$. Dausman, Crime and Criminals, 36 AM. L. Rev. 661, 678 (1902). Possibly, both Curry and Dausman were building upon suggestions for jury-based determination regarding the "act" that had long been part of the debate over use of experts to determine the "criminal" element in legal-insanity cases. 
change. ${ }^{54}$ But we can also now see how much - from the scientific point of view - got compromised along the way. Americans made some significant attempts to reform their penology, but they stood fast with regard to the criminal trial and the legal definition of criminal responsibility, thus deepening the bifurcation of the two main stages of criminal process and increasing at least the appearance of irrationality. ${ }^{55}$

The rejection of a thoroughgoing "scientific" approach — in the name of a defense of both the concept of free will and the principle of political liberty - exacted costs and accrued benefits that can never be weighed and evaluated, save through the lens of our own political preferences. We can, however, identify one "benefit" of the traditionalism pervading Progressive-era penology that most of us would count very heavily on the positive side. I mention it because it both brings us to another of Speranza's deepest concerns and reminds us of an enduring aspect of the "Anglo-Saxon" approach to human freedom and social justice.

You will recall that the new schools of behavioral science were divided on the practical applications of their theories. Among the matters on which there was disagreement was the question, what to do with incorrigibles? Who were "incorrigibles"? According to the new scientists, heredity or environment or disease of the brain could produce a propensity to engage in behavior that the state defined as criminal. In some cases, this propensity was reversible, in others not; scientists differed in their assessment both of the pathology involved and of the likelihood of response to those currently available treatments. All agreed that some persons would never respond in the manner implied by the concept of "cure," but the universe of such incorrigibles was different for different students of human behavior. Moreover, some incorrigibles lacked the cognitive processes necessary for cure, while others possessed those capacities but were so lacking in social conscience that nothing could be done. Should all be treated as insane and "humanely" cared for until they died? Should some be so treated and others not?56

54. See Rotrman, supra note 8.

55. This was a largely unacknowledged compromise: most contemporary reformers did not directly contrast the two stages; they focused on sentencing, as though the issue of criminal guilt was off-limits, or simply a lost cause.

56. Generally speaking, an author's views on the existence of incorrigibles and the possibility of reforming or curing them were linked to beliefs about the causes of crime. Strict hereditarians, though rarely suggesting that all criminals were bom criminals, usually supported the notion that incorrigibles required permanent segregation or even execution. See, e.g., W. Duncan MCKIM, HeREdITY ANd Human PRogress 97 (New York, Knickerbocker Press 1899); Address by Henry Hatch, Crime and Criminals, and What Shall Be Done With 
Americans had long been exposed to the doctrine that criminal law ought not to be based on revenge or retribution, but ought instead to look to a mixture of cure and prevention. If cure was impossible, prevention might still be an option. Permanent incarceration was one form of prevention, but, as Americans came to see over the course of the nineteenth century, it had two drawbacks. First, it was expensive; second, it was strong medicine for recidivists whose crimes were relatively minor. The threat of this degree of incapacitation ("specific deterrence") might deter others ("general deterrence"), but the proportionality between the harm a convict had caused society and the hardship visited upon him might offend one's sense of justice. Just how thoroughly "scientific" ought one to be in the name of prevention?

By 1900, a few American scientists who studied criminal behavior were coming to share a perspective that some continental criminologists and penologists had introduced into the transatlantic literature of the late nineteenth century, an extreme and "therapeutic" form of the social defense position. It took the scientific premises of human behavior and the social policy of prevention to their logical conclusions; some of the leading behavioral scientists were among those who now seem to us the most cold-blooded on the question of remedy. Some favored "benign" - nonretributive execution or "elimination"; others counseled permanent incarceration of recidivists, however minor their recurring crimes. In AngloAmerican circles, the proponents of this form of the social defense concept could be found among those who had been influenced by Herbert Spencer's Social Darwinism. 57 Should we be entirely surprised to find in the American Law Register of 1904 an article by Gino Speranza that criticized American penology under the title of The Survival of the Weakest as Exemplified in the Criminal?58

Them, in 1904 Proc. of the ANN. Congress of the NATL. Prison Assn. 302. Environmentalists could express support for the possibility of curing some criminals, with indeterminate sentences to deal with possible incorrigibles. See, e.g., Henry Maudsley, The Moral Sense and Will in Criminals, 2 Medico-Legal J. 1 (1885). Most often, as Frances Kellor noted in 1901, American criminologists drew on both the Italian (hereditarian) and French (environmental) schools in thinking about the causes and, hence, treatment of crime. See Francis A. Kellor, Experimental Sociology: Descriptive and ANalytical: Delin. QUENTS 1-5 (1901); see also Francis Wayland, Incorrigible Criminals, 23 J. Soc. ScI. 140 (1887); Address by Francis Wayland, The Incorrigible - Who He Is, and What Shall Be Done With Him, in 1886 Proc. of the NAtL. Prison Congress 189, 189-93 (Chicago, Lakeside Press 1887).

57. See, e.g., Henry M. Boies, The Science of Penology (1901); G. Frank Lydston, The Diseases of SOCIETY (1904).

58. Gino Carlo Speranza, The Survival of the Weakest as Exemplified in the Criminal, 43 AM. L. REG. n.s. 159 (1904) [hereinafter Speranza, Survival]. For earlier articles by Speranza that point in the same direction, see Gino C. Speranza, The Coefficients of Impunity, 39 AM. 
Speranza's 1904 article reflected a mixture of compassion and severity, of treatment and repression. Prison was inappropriate and, indeed, counterproductive for those persons who were merely "mistaken," having been temporarily led astray by social conditions or circumstances. A system of probation or, at least, early parole was needed, and Speranza took the opportunity to berate American penology for its backwardness in this regard. The reforms he favored were only slowly coming into existence in most states, though they would soon come, quite universally, with a great rush. As for the true "criminal class," which was much smaller than most Americans recognized,

it deserves most repressive measures against it for the social good.... The truly criminal are a danger, and the hope of reforming them is almost a negligible quantity....

... [T] he whole juridic framework must be erected on the modern lines of the social defence. The conception of punishment as a defence to crime has gone into bankruptcy: it neither defends nor deters. Criminal therapeutics must take its place; that is, where a cure is possible, let the remedial agencies suggested by criminologic and sociologic science have full scope. But where juridic therapeutics fail, let there be no mistaken altruism to perpetuate the unfittest. 59

What Speranza most feared was that the new penology, when it came, would serve to condition the truly criminal to act as though they were reformed though in fact they were not, and so make those least fit for social existence the most adept at negotiating the conditions of existence in modern society. A proper system of scientific evaluation of human behavior would facilitate the separation of the treatable from the incorrigibles - the "truly degenerate," thus the "truly criminal" in the scientific, not moral, sense - but it would have to be "based on more reliable, tangible, and positive tests than the somewhat vague and uncertain theory of the forces of good and evil in man and their control by the spirit or the will." 60

L. REG. n.s. 647 (1900) [hereinafter Speranza, The Coefficients of Impunity]; Gino C. Speranza, What Are We Doing for the Criminal?, 40 AM. L. REG. n.s. 215 (1901); Gino C. Speranza, Society's Defense Against the Criminal, 63 ALB. L.J. 12 (1901); Gino Carlo Speranza, Criminality in Children, 15 GREEN BAG 516 (1903) [hereinafter Speranza, Criminality in Children].

59. Speranza, Survival, supra note 58, at 163, 165-66. Three years earlier, Speranza had declared: "Let us hope that the day is near when the volume of our laws, which bears the title 'Crimes and Their Punishments,' will be replaced by a treatise on 'The Therapeutics of Crime.'" Speranza, What Are We Doing for the Criminal?, supra note 58, at 220.

60. Speranza, Survival, supra note 58 , at 166 . Speranza was by no means alone among lawyers in his views regarding penology. See, e.g., Charlton T. Lewis, The Indeterminate Sentence, 9 YALE L.J. 17, 27 (1899); see also Warner, supra note 23. Both Lewis and Warner were leading penologists. 
Thus, in the end Speranza chose science over free will, in this particular context. The compromise he had recommended three years earlier regarding assessment of responsibility had given way to the exigencies of social defense against serious crime regarding determination of treatment. American penology, however, was to prove only partly responsive to the nonretributive social defense theorists - whether of the strictly utilitarian or of the scientificpositivist stripe. Progressive-Era reforms were to reflect a mixture of new and traditional concepts of human behavior. Many Americans favored retention of capital punishment or long-term incarceration for serious felonies and were skeptical of the naive optimism on display in the new system of probation, indeterminate sentences, and parole, as it applied to less serious felonies; they resolutely held to a notion of retribution. Serious offenders - even incorrigibles - were morally evil persons who refused to obey the law and who therefore deserved the worst. Between the most traditional and the deterministic-social-defense theorists there was a certain shaky alliance of the sort that, in France, had created a "politics of social defense,"61 but this alliance was based solely on agreement regarding results, and only with respect to incorrigibles. With regard to treatable offenders, and with respect to the premises upon which criminal responsibility rested, the two camps could not have been farther apart.

Americans - or American society as a whole - took a middle road, mixing the rhetoric of social determinism with the language of free will and drawing lines accordingly, if irrationally. But it was largely resistance to the new science, and to its deterministic premises, I believe, that led Americans at large to reject a strictly therapeutic version of social defense. The scientific concept of the "incorrigible" would remain subject to question; relatively few convicts would be thought of in that way. ${ }^{62}$ Most criminals, we seemed

61. See NYE, supra note 6, at 171-226.

62. There were, however, 16 states that passed some form of a sterilization law between 1907 and 1917. It should be pointed out that most such laws were aimed at the insane or feebleminded, although they often included habitual criminals, drunkards, and sex offenders as well. By 1931, the number of criminals among the roughly 12,000 individuals sterilized since 1907 was very small. See MARK H. HALIER, EugenICS: HEREDITARIAN ATITTUDES IN AMERICAN Thoughr 133-41 (1963); see also AlleN, supra note 6, at 41. Referring to the eugenics movement as a whole (rather than to its application to those specifically convicted of criminal offenses), Allen notes that the eugenics movement "for the first three decades of the present century rivaled the rehabilitative ideal in its appeal to the educated and influential segments of the community." Id. Hovenkamp notes that between 1907 and 1926, 23 states enacted sterilization laws: "Some of the laws were aimed at criminals, but many were much broader statutes, part of the eugenics movement to improve future generations through the sterilization of people whom the state had reason to believe were mentally defective." Hovenkamp, supra note 6, at 563 n.75; see also KENNETH M. LUDMERER, GENETICS AND 
to believe, had chosen to do wrong and, if they possessed cognitive abilities, both deserved punishment and were probably reformable: Under the right conditions, they would choose, freely, to do right. Although actual conditions of imprisonment typically made a mockery of our ideals, most Americans remained convinced that the inalienable "Anglo-Saxon" rights to freedom and to due process required both the opportunity for rehabilitation within a system of reasonable punishment and constant adherence to the concept of free will. Whatever the social benefits, the social and personal costs of an openly deterministic social defense theory were too high. They both offended the prescript of political liberty against restraints imposed by the state and offended the deeply held faith that human worth and free will were, in the last analysis, one and the same.

The criminal law has never fully recovered from the fin de siècle critique launched by the new scientists. The route to general social disillusionment with criminal justice administration has been circuitous. Progressive-Era penitentiaries had much less capacity to rehabilitate than their enthusiasts hoped or expected. More recent penologists have rejected indeterminate sentences as ineffective, and even fraudulent, devices whereby many offenders are incarcerated far longer than they need or ought to be. Rather than reform and achieve parole, many offenders, quite predictably, stagnate and remain under lock and key. The science that fostered the new penology subsequently devoted much time and energy to explaining why rehabilitation of offenders often did not take place; the position of rehabilitation's critics has been strengthened through the colorable claim that, from the perspective of traditional principles of legal and human rights, the resulting long-term incarceration was unjust. 63

But the post-Progressive-Era crisis in penology is not the whole story. Less noticed, perhaps, has been the gradual de facto break-

AMERICAN SOCIETY (1972). For a description of the early findings on sterilization, see H.C. Sharp, Rendering Sterile of Confirmed Criminals and Mental Defectives, in 1907 Proc. of tFe ANN. CONgress of tHe NATL. Prison Assn. 177. Sharp performed some of the first vasectomies in the country, on consenting boys at the Indiana Reformatory, and some of the first legally required ones, under the 1907 Indiana statute, Act of Mar. 9, 1907, ch. 215, 1907 Ind. Laws 377, which was the first of its kind in the United States.

63. See AlLEN, supra note 6, at 32-34, 44-49. Allen provides a subtle assessment of the many kinds of claims regarding the failure of rehabilitation attempts, and notes how modern supporters of a "just deserts" doctrine have pointed to these failures in their criticism of the use of long-term and indefinite incarceration. Id. at 51-52, 57-58, 66-69. David Rothman discusses the vicissitudes of modern penology, including the critique of the rehabilitative model, in The Crime of Punishment, N.Y. REv. Books, Feb. 17, 1994, at 34. 
down of the bifurcation of trial and punishment upon which the traditional concept of criminal responsibility had come to depend. The deterministic language of penology has inevitably fed back into the earlier, guilt-determination stage of criminal process. Or so some commentators have thought - including, as it happens, Speranza, who was among the first to address the question of jury behavior in this fashion. We do well to conclude our discussion of the fin de siècle with a brief return to Speranza's writings, this time to his comments on the criminal trial jury.

The jury has, of course, occupied a special place in relation to tensions among conventional morality, the "science" of human behavior, and the rule of law; practically the entire history of the jury in the Anglo-American tradition could be analyzed in these terms. ${ }^{64}$ Not surprisingly, most late-nineteenth and early-twentiethcentury commentary on the relationship between jury behavior and legal rules reveals only a limited understanding of these tensions. It is worth noting some aspects of that commentary before returning to Speranza.

The doctrine of the jury's right to find law as well as fact had been largely, though not quite entirely, rooted out of American jurisprudence across the later decades of the nineteenth century. ${ }^{65}$ Juries continued, of course, to deviate on occasion from formal judicial instructions on the law, a phenomenon of nullification that increasingly .earned the epithet of "lawlessness," even as it set in motion the modern debate over the jury's "right" so to act when it feels morally compelled to do so. As the law-finding doctrine declined, legal writers turned their attention to the "science" of factfinding, and in doing so they often criticized jurors as unintelligent, too sympathetic, or otherwise guided by their emotions. ${ }^{66}$ For a

64. This is, in general terms, the subject of the larger project on which I am engaged. I have drawn many of the informal observations in this essay from my ongoing research. I have also touched upon this particular issue in my book, VeRDICT ACCORDING TO CON. SCIENCE, supra note 14, at v, 267-317, 356-83.

65. The most comprehensive account of the demise of the law-finding doctrine remains Mark DeWolfe Howe, Juries as Judges of Criminal Law, 52 Harv. L. Rev. 582 (1939). For discussion of the criminal trial jury in the late-nineteenth and early-twentieth centuries, see, for example, LaWrence M. Friedman \& Robert V. Perctval, The Roots of Justice 182-95 (1981); Albert W. Alschuler \& Andrew G. Deiss, A Brief History of the Criminal Trial Jury in the United States, 61 U. CHI. L. Rev. 867 (1994); David Millon, Juries, Judges, and Democracy, 18 LAW \& Soc. INQUIRY 135, 154-57 (1993) (book review).

66. On the (lack of) intelligence issue, see, for example, Trial by Jury, an unsigned comment from the Chicago Legal News, reprinted in 2 ALB. L.J. 159, 159 (1870): "[O]ur jury quit their shops for the courts of justice; they march straight from the weighing of cheese to the weighing of testimony; from dealing in candles and bacon, to dealing with the lives, properties and liberties of men." On the emotions of jurors, see, for example, J. Kopelke, Criminal Law Reform, 29 ALB. L.J. 148 (1884), where the author notes 
time, optimistic reformism accompanied the endemic cynicism. Some commentators looked forward to a new era of jury deliberations characterized by rational decisionmaking in accordance with existing legal rules. ${ }^{67}$ Others opined that Americans had much to learn from the contemporary English model of the criminal trial, wherein swift selection from a more highly qualified pool produced a more intelligent and less willful jury, one that listened respectfully to a bench empowered to comment upon the evidence and to issue firm and pointed instructions. ${ }^{68}$ Taken as a whole, however, the commentary of the period does not reveal great confidence in lay assessment of "fact," in jury-based assessment of evidence that proceeded by way of reason and was consistent with legal standards, but was responsive as well to community-based understandings of language, mentality, and physical behavior.

By Speranza's day, doubts about the possibility of a truly ra- tional jury process matched - or outweighed - optimistic impulses. All the same, few lawyers responded favorably to some behaviorists' call for replacing the lay jury with a panel of "experts," even in legal insanity cases. Perhaps lawyers were coming to see the principles of the new science as even more threatening than the worst excesses of jury behavior. Indeed, it may be that some of the lay jury's most severe juristic critics saw that institution as the last line of defense against the scientists' attack on the orthodox approach to criminal responsibility. Thus, although lawyers and scientists agreed that criminal process ought to be made more rational, and although both singled out the jury and the myriad "technicalities" of the law that recourse to the jury entailed as a prime site for reform, there were distinct limits to this area of agreement. If the two camps were destined to remain apart - especially regarding use of a lay jury to determine the issue of legal insanity -

an inclination in the mind of the average juryman to rather believe in the innocence of a man than in his guilt, frequently even in disregard of the evidence offered, or even if convinced of guilt, then at least to make the punishment light. It is a kind of sentimentalism, which of course the counsel for the defense try their utmost to kindle and turn to the advantage of their client.

Id. at 148.

67. For a discussion of the way in which jurors ought to go about the business of finding fact, see, for example, Charles E. Grinnell, Beyond a Reasonable Doubt, 9 GREEN BAG 97 (1897). Grinnell noted the many obstacles to good jury decisionmaking, but seems to have believed that, with some reforms, the system could yield acceptable results.

68. The debate over the virtues of the English system of jury trial stretched from the 1870 s (if not earlier) into the 1920s (and beyond). In 1909, the American Institute of Criminal Law and Criminology (AICLC) charged a committee with study of the English system. See infra text accompanying note 102. Late-nineteenth and early-twentieth-century commentary on the comparative advantages and disadvantages of the English approach to jury trial in criminal cases was voluminous. 
within the legal world itself a similar form of disagreement was bound to make itself felt. The more "scientific" the jurist, the more the jury required reining in - but, then, only to a point. At that point, the more fundamental difference between lawyer and scientist kicked in. What, we may wonder, is really different today in this regard?

The full story of the fin de siècle interplay among these warring elements awaits treatment on another occasion. For present purposes, we must note that jurists roundly criticized the jury from many angles, including importantly that institution's supposed adherence to "frontier justice." For the most part, this criticism was premised on the assumption that jurors brought parochialism, naivéte, and downright ignorance to their task. ${ }^{69}$ Often it is difficult to determine the precise perspective of those who commented upon the jury, especially those who pointed to jurors' leniency. From the late nineteenth century to our own day, both the endorsement and the criticism of jury "sympathy" has frequently been embodied in language that conceals the critic's true perspective, if indeed the critic has focused clearly on what it is that pleases or galls him. In this regard, interpretation of Speranza poses a special problem. He said little about the jury and he used some conventional phrases without tying them to particular kinds of cases. What mainly must be kept in mind is that, among lawyers, Speranza's attempt to make sense of de facto law-finding was unusual, for he spoke from the perspective of behavioral science. At some point - it is not clear just when - he came to see jury behavior as a response to new ideas, and in that sense positive, but also as confused and born of frustration. Moreover, like most true behavioral scientists, Speranza favored top-down reform; the conscience of the community had its place, but it could not bear the entire burden of remaking an out-moded and irrational process of criminal justice. He appears to have traveled a path that some others were taking during the first decade of our century, one that even some other lawyers trod, but - once again - his behaviorist and deterministic perspective led

69. Often, these concerns were tied to a view of the jury as "untrained" or "unscientific." See, e.g., T.D. Crothers, A Psychological Study of Jurors, 60 ALB. L.J. 341 (1899); Current Topics, 54 AL.B. L.J. 17, 23-24 (1896) (quoting George Hoadley's comments on the topic). Such attitudes assumed jurors were easily played upon by counsel. See, e.g., G. Carlton Jackson, Jurors by Occupation, 13 VA. L.J. 25 (1889); Edward A. Thomas, Shall the Jury System be Retained?, 3 THE FORUM 102, 107-08 (1887). On occasion, criticism was linked to tensions over the question of the jury's role in law-finding. See, e.g., Orville C. McLaughlin, Trial by Jury, 64 ALB. L.J. 286, 287, 289 (1902). 
him to a solution that had both the virtue of consistency and the defect of total impracticality.

Speranza's comments on the jury are scattered throughout his work. He never wrote extensively about the jury per se, but discussed it where it bore relation to his central interests. His earliest remarks were conventional: Like many others, lawyers and behavioral scientists alike, he criticized the "emotional and hysterical acquittals of persons guilty of taking the law into their own hands to avenge their honor."70 Speranza applied this criticism to his observation that there was a widespread "social complicity with crime," which undermined the principle of the social defense. ${ }^{71}$ But Speranza did not settle entirely for the generalities about misplaced "pity" or "sympathy" so common in the period. In his 1903 article Criminality in Children he appears to have taken a further step.

Careful study will show that the tenderness of the law in its provisions regarding special cases, and more especially the tenderness in its application in given cases, has its reason not so much in the unfitness of the punishment to the crime as in its unjust and unfair application to those who are not the real culprits. Thus the theft of bread is larceny, and larceny should be under the ban of the law; but the hungry man who steals a loaf would probably go free because the trial jurors would say: "It was not he who stole - but the Social Conditions that let him get hungry." And more clearly, if a child kills his playmate, the jury will almost instinctively attribute the child's malevolence to the indifference or maliciousness of the parents. ${ }^{72}$

Speranza might have been invoking age-old notions of human motivation, despite the modern ring of his language. Nearly a decade later, he made himself clear. By then others, too, had begun to suggest that jurors sometimes reflected progressive notions; they were not always simply, and habitually, "sympathetic," or "sentimental," but were occasionally ahead of the law in grappling with the social origins of crime. ${ }^{73}$ In 1912, Speranza opened New Horizons in Penal Law with the assertion that "[p]ublic opinion is growing restless over the administration of the criminal law."74 In noting that jurors registered this discontent he suggested that "[t]he fact is that the popular mind has come to make part of its convictions the reforms contended for by penologists for over a century regarding the basic principles of the function of the state towards the crimi-

70. Speranza, The Coefficients of Impunity, supra note 58, at 652 .

71. Id. at 652-54.

72. Speranza, Criminality in Children, supra note 58 , at 516 (emphasis added).

73. See infra text accompanying notes 177-88.

74. Gino C. Speranza, New Horizons in Penal Law, 18 CASE \& Com. 745 (1912). 
nal."75 At times the jurors in exercising lay judgment risked breaching social defenses. Thus did Speranza, in this, his final article on criminal responsibility, ${ }^{76}$ explain how "reformers and laymen have, under the impulse of such discontent, carried their protest beyond just bounds, by extending sympathy where it was not deserved - resulting often in hysterical verdicts - and thereby exposing themselves to the just charge by conservatives of a desire to override the law."77

The "basic principles" of the "new penology" that Speranza invoked might, he said, be called "more humane," but he preferred to style them "more just because ... more rational." He called for the "swift application of suitable discipline," which in most cases would be work. ${ }^{78}$

I call it discipline for want of a better word; for it is not punishment and it is not mercy, but a social means to a social end. Such end is that society shall be protected; and such protection modern penal law must attain by different means, varying from the simple fact of conviction, with no other penalty ... to the absolute elimination of the transgressor from society. ${ }^{79}$

Speranza noted that "[p]ublic opinion revolts against [an offender's] elimination by death," but opined that "it would approve perpetual exclusion from society in a penal colony." $80 \mathrm{He}$ concluded with the observation that "[ $\mathrm{t}]$ he old saying that "the punishment must fit the crime' is but the precursor of the modern principle that the discipline must fit the criminal"; if the fit was proper, "juries would not acquit against their oath."81 Presumably, absent the prevailing tension between their increasingly scientific understanding of crime and the traditional retributive approach to penology, jurors would accept the exigencies of the concept of the social defense.

Speranza's insight was, of course, just that: his own way of understanding a form of jury behavior that most fin de siècle and early-twentieth-century commentators described, without more, as foolish sympathy. Nonetheless, there is reason to believe that Sper-

75. Id. (emphasis added).

76. Speranza would go on to write many more articles dealing with the problems faced by immigrants, a subject to which he had devoted considerable energy since the turn of the century.

77. Speranza, supra note 74 , at 745.

78. $I d$.

79. Id.

80. Id. at 746.

81. Id. 
anza - and a few other commentators - weren't far off the mark. Indeed, from the perspective of our own day, it would be surprising if the rhetoric of determinism had not gradually affected the understanding of society at large, as popular journals, newspapers, and novels referred more and more to the factors that conditioned criminal behavior. One might conjecture that increasingly across the decades of our century the ritual of the trial stage has been thoroughly adulterated. We have gradually come to reflect our often subconscious ambivalence regarding the doctrine of mens rea, our underlying doubts about the criminal law's general presumption of free will. Although we know that rehabilitation rarely works, we accept much of the behavioral-science analysis of crime and we thus often intuitively balk at assigning a full measure of guilt. Fortunately, we are not often tested in this way, as most cases end in guilty pleas on a "bargain": If the defendant "freely" chooses to plead guilty, doubts about his having freely chosen to commit the underlying offense are paved over - or simply not addressed.

\section{The Progressive Era: Pound}

\section{A.}

Speranza wrote little on the problem of criminal justice after 1904. His parting shot, the 1912 essay New Horizons in Penal $L a w, 82$ bears the influence of the widespread concern with penology of the early years of the American Institute of Criminal Law and Criminology (AICLC), an organization in which Speranza played a minor official role from 1911 to 1913.83 The issues the young Speranza had struggled with have, of course, remained central to criminal justice. And Speranza's advice in his 1901 paper has proved prophetic. Proponents of a strictly scientific approach to criminal responsibility have made little impact upon the daily life of the

82. Speranza, supra note 74.

83. Speranza served as chair of the Committee on Crime and Immigration. See 1 J.C.L.C. 680 (1911); 4 J.C.L.C. 523, 523-27 (1913). Speranza's interests in legal matters, increasingly more practical than theoretical, lay in the rights of immigrants before the law and in the problem of criminality among immigrants generally. His more literary and journalistic new horizons lay just ahead: a war-years shift in perspective on assimilation made him a prolific publicist of the virtues of Americanization. For Speranza, Progressivism ultimately meant an Anglo-Saxon version of the melting pot experience. Whether his views on criminal responsibility also melded into the "Anglo-Saxon" paradigm we can not know, for either out of frustration or lack of interest, he stopped writing about it. See Anthes, supra note 29. Anthes portrays the post-War Speranza as opposed to the traditional notion of the "melting pot," opposed to further immigration. Speranza increasingly identified with the Anglo-Saxon "spirit" and saw that "spirit" as threatened by further large-scale immigration. He had himself (as he saw it) already melted into the "old stock" culture. Id. at 29. 
law; 84 attempts at a middle ground have dominated, melding the insights of behavioral science with a lawyer's perspective.

The tensions and anxieties of the fin de siècle gave way to the more optimistic reformist perspective of high Progressivism, and to an attempt - albeit temporary - at rapprochement between scientist and lawyer. Legal thinkers could not help being affected by the "scientific" ideas that lay all about them. If the great bulk of them affirmed ideas that were more or less compatible with the conventional understanding of criminal responsibility, many nonetheless followed the scientists' lead in approaching penology in decidedly behaviorist terms.

The founding era of modern criminal justice administration stretches from the 1870s down to the 1920s; the latter half of that period, the Progressive Era, constituted the chief moment of experimentation, advances, and overall consolidation. This was true at the front end of criminal process, with respect to the professionalization of police and investigatorial practice; and at the back end, with respect to the use of probation, indeterminate sentence, and parole, the recourse in some states to sterilization, and the attempt to reform prison conditions to the standards of the rehabilitative ideal. ${ }^{85}$ The guilt-assessment stage, however, at least with regard to the more serious felonies, witnessed fewer initiatives: The substantive law remained largely intact, and, despite a great deal of agitation, trial procedure did as well. ${ }^{86}$ If the guilt-assessment stage saw significant change, it was in the ever-increasing number of defendants who avoided trial by pleading guilty. ${ }^{87}$

84. E.g., Karl Menninger, The Crime of Punishment (1968).

85. See, e.g., Friedman \& Percival, supta note 65; Blake McKelvey, Amzrican Prisons: A History of GoOd INTENTIONs 234-66 (1977); RotTMan, supta note 8; SAMUel WALKer, Popular Justice 127-60 (1980); see also Alexander W. Piscotta, Benevolent REPRESSION: SOCIAL CONTROL AND THE AMERICAN REFORMATORY-PRISON MOVEMENT (1994). Piscotta traces the vicissitudes (mainly failures) of the adult reformatory movement from 1876 to 1920 .

86. Transformation of trial practice did occur in the juvenile courts; this increased the pressure for reform of the regular courts, but to no avail. See STEVEN L. ScHLOSSMAN, Love and the American Delinguent: The Theory and Practice of "Proaressive" Juve. NILE JUSTICE, 1825-1920 (1977); see also FRIEDMAN, supra note 6, at 413-17. For a contemporary account, see John P. Briscoe, Reforms of the Criminal Law, 8 J.C.L.C. 653, 653-54 (1918). George Kirchwey, President of the AICLC, recommended in 1918 the extension of juvenile court practice to adult courts. See George W. Kirchwey, Proceedings of Tenth Annual Meeting of the American Institute of Criminal Law and Criminology: President's Address, 9 J.C.L.C. 327, 337 (1918).

87. See, e.g., Friedman, supra note 6, at 250-52, 390-91; Friedman \& Percival, supra note 65, at 174-81; Albert W. Alschuler, Plea Bargaining and Its History, 79 CoLuM. L. REv. 1 (1979); see also Reginald Heber Smith \& Herbert B. Ehrmann, The Criminal Courts, in Crmminal Justice IN Cleveland 229, 237 (Roscoe Pound \& Felix Frankfurter eds., 1922). 
The most famous manifestation of this early-twentieth-century program in criminal justice was the formation - by Roscoe Pound among many others - of the AICLC in 1909.88 Itself a manifestation of the emerging working relationship between scientists and lawyers, the Institute's publication, The Journal of Criminal Law and Criminology, aired all the leading issues of the day, matters of practice as well as more theoretical concerns. The work of the Institute was carried on primarily through committees, 89 whose endeavors intersected with national and state bar association committees, state legislative commissions, sub-groups of medical and psychiatric associations, associations for prison reform, and state crime commissions. From these organizations there came a deluge of writings that, together with the state and municipal criminal-justice surveys of the 1920s that Pound helped to organize, form the foundation for modern criminal justice scholarship. We do well to pause for a moment to take note of this founding generation, before turning specifically to Pound.

The reformist writing of the early-to-mid teens ranged over every stage of criminal justice administration: investigatorial technique, prosecutorial bureaucracy; 90 trial procedure including, inter alia, the rules of evidence, the role of the judge, and the scope of the jury's authority; 91 and - most importantly - penology and the treatment of the insane, the feeble-minded, and juvenile offenders. ${ }^{92}$ From outside the legal profession the dominant thrust continued to center on the causes of anti-social behavior. Alongside

88. The AICLC was an outgrowth of the National Conference on Criminal Law and Criminology held in Chicago, June 1909. See 1909 Proc. of tFE FIRST NATL. CoNF. ON CRIM. L. AND CRImInology [hereinafter Proceedings]. For a brief discussion of the Chicago Conference and the creation of the Institute, see James W. Gamer, Editorial Comment, 1 J.C.L.C. 2, 25 (1910). See also Davm Wigdor, Roscoe Pound: PHILOSOPHER of LAW 142-45 (1974).

89. See 1 J.C.L.C. 677, 678-82 (1911) (listing the various committees).

90. See, e.g., Robert H. Gault, review of MAYER C. Goldman, The Public DefEnder: A NECESSARY FACTOR IN THE ADMINISTRATION OF JUSTICE, 8 J.C.L.C. 315-16 (1917).

91. See, e.g., Jesse L. Deck, Some Needed Reform in Criminal Procedure, 8 J.C.L.C. $325-$ 36 (1917); Charles W. Eliot, The Popular Dissatisfaction with the Administration of Justice in the United States, 25 GREEN BAG 65, 66-67 (1913); Edward J. McDermott, Delays and Reversals on Technical Grounds in Civil and Criminal Trials, 7 PROC. AM. POL. Scr. AssN. 97 (1910); William E. Mikell, Reform in Criminal Procedure, 52 AnNaIs AM. ACAD. POL. \& Soc. ScI. 102 (1914); Samuel Scoville, Jr., The Evolution of Our Criminal Procedure, 52 ANNALS AM. ACAD. POL. \& Soc. Scr. 93, 96-99 (1914); Edson R. Sunderland, The Inefficiency of the American Jury, 13 Micr. L. REv. 302, 302-05, 310 (1914).

92. See, e.g., George G. Battle, The Problem of the Disposition of Insane Criminals, 1 VA. L. Rev. 108 (1913); Robert H. Gault, The Method of Treating the Criminal Insane in Germany, 4 J.C.L.C. 5 (1913); Bemard Glueck, Concerning Prisoners, 2 Mental HygIENE 177 (1918) [hereinafter Glueck, Prisoners]; Bernard Glueck, Psychiatric Aims in the Field of Criminology, 2 Mental HygIENE 546 (1918) [hereinafter Glueck, Psychiatric Aims]. 
notions of human behavior based mainly on hereditarian influences, there had long since emerged an environmentalist perspective. To this the fin de siecle added Freudian and other forms of psychoanalysis. ${ }^{93}$ Classic studies in behaviorism soon followed. ${ }^{94}$ Naturally, there were multifaceted constructs that drew upon all of these insights. ${ }^{95}$ Contemporary advances in behavioral science to which Pound paid at least glancing attention - focused not only on the genesis of "crime," but also on the treatment of offenders. Though these advances grappled with the concept of responsibility generally, they paid special attention to the problem of legal insanity. In this context, behavioral-science scholars took a leading role in recommending reform of trial procedure; alongside some legal writers, they criticized the prevailing insanity test, ${ }^{96}$ argued for revision of the rules concerning presentation of expert testimony, ${ }^{97}$ and took on the question of the role of both judge and jury. ${ }^{98}$

Legal scholars shared the intense interest in the insanity defense, but their increasing participation in this regard did not lead many of them to agree with the most radical of the behaviorists. As they had since the middle decades of the nineteenth century, legal

93. See, e.g., Nathan G. Hale, Freud and the Americans: The Beginnings of PsyCHOANALYSIS IN THE UNITED STATES, 1876-1917 (1971); AMERICAN PsychoANALYSIS: ORIGINS AND Development (Jacques M. Quen \& Eric T. Carlson eds., 1978).

94. See, e.g., William McDougall, AN Introduction to Social Psychology

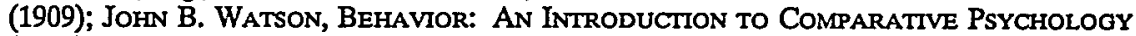
(1914); see also RAY Madding MCConNeli, Cruminal ResponsibILITY aNd SOCIAL CoN. Straint (1912); Maurice Parmelee, The ScIENCE of Human Behavior (1913).

95. For contemporary studies applying various of these behavioral science approaches to crime, see, for example, Edwin G. Conklin, Heredity and Responsibility, 37 SCIENCE 46, 49-51 (1913); Charles B. Davenport, Heredity, Culpability, Praiseworthiness, Punishment and Reward, 82 Popular Sci. MONIHIY 33 (1913); Charles G. Davis, The Psychology of Crime and Criminals and the Stigmata of Degeneration, 19 CASE \& COMMENT 820 (1912); Glueck, Prisoners, supra note 92, at 177-78, 180, 198-99; Glueck, Psychiatric Aims, supra note 92, at 546, 550-53; Maurice Parmelee, $A$ New System of Criminal Procedure, 4 J.C.L.C. 359, 366-67 (1913).

96. See, e.g., Herman Adler, Organization of Psychopathic Work in the Criminal Courts, 8 J.C.L.C. 362 (1917); Frank H. Bowlby, Insanity as a Defense in Homicide Cases (pts. 1 \& 2), 17 Case \& Comment 491, 554, 558-60 (1911); Herbert J. Friedman, Comment on Recent Judicial Decisions, 1 J.C.L.C. 612, 615-17 (1910); Edwin R. Keedy, Tests of Criminal Responsibility of the Insane, 1 J.C.L.C. 394, 400-02 (1910); Edwin R. Keedy et al., Insanity and Criminal Responsibility, 7 J.C.L.C. 484 (1916); Philip Coombs Knapp, Criminal Responsibility, 6 J.C.L.C. 571 (1915); Carlos F. MacDonald, Expert Evidence in Criminal Trials, 1 Proc. ACAD. PoL. SCI. 641, 658-59 (1911); Henry Rutgers Marshall, Proceedings of the Conference on the Reform of the Criminal Law and Procedure Held in New York, May 12 and 13, 1911, 1 Proc. ACAD. POL. SCI. 705, 714-17 (1911).

97. On criticism of expert witnesses in insanity cases, see 1910 Proc. WISCONSIN BraNCH AM. INST. Crm. L. \& Crimmology 30 (Conference held Nov. 26-27, 1909); Eliot, supra note 91, at 69; Glueck, Psychiatric Aims, supra note 92, at 548-49; MacDonald, supra, note 96.

98. On the jury, see Battle, supra note 92, at 114-18; Bowlby, supra note 96, at pt. 2, 55759; MacDonald, supra note 96, at 646; Parmelee, supra note 95, at 361-62. 
scholars and practitioners continued to seek reform of, but nonetheless to work within, the prevailing system of jury trial. In part, they were responding to the decision of the Supreme Court of the State of Washington in State v. Strasburg, ${ }^{99}$ invalidating legislation abolishing the insanity defense as unconstitutional - and commenting along the way on the limited implications of the new criminological theory for the traditional social and legal concepts of guilt. ${ }^{100}$ The movement for such legislation reflected an odd marriage of interests between scientists, and some jurists, who considered the jurisprudence of insanity archaic and many other jurists,

99. 110 P. 1020 (Wash. 1910).

100. The legislation at issue provided for postconviction mental examination in cases in which state officials thought it appropriate. The court held that:

To take from the accused the opportunity to offer evidence tending to prove [insanity] is

in our opinion as much a violation of his constitutional right of trial by jury as to take

from him the right to offer evidence before the jury tending to show that he did not

physically commit the act....

110 P. at 1024.

The court also noted "the very able and ingenious argument . . based upon the seeming assumption that the modern humane treatment of those convicted of crime practically removes them from the realm of punishment ..." 110 P. at 1025. The court quoted extensively from counsel's brief on this point:

"The central idea upon which the whole fabric of criminal jurisprudence was formerly built was the idea that every criminal act was the product of a free will possessing a full understanding of the difference between right and wrong and full capacity to choose a right or wrong course of action.... A better understanding of crime and the science of criminology now convinces us that this theory is wholly wrong - that a dominant percentage of all criminals are not free moral agents, but, as a result of hereditary influences or early environments, are either mentally or morally degenerate . . .."

110 P. at 1025 . The brief, as quoted by the court, then asserted that older forms of punishment "are giving way to workhouses, reformatories, and asylums, the purpose of which is to instruct, educate, and reform rather than further to debase the individual, and the modern systems of criminal classification and segregation are themselves a recognition of the fact that every criminal is a concrete problem." $110 \mathrm{P}$. at 1025 . The court then stated:

The argument seems to be in its last analysis that, because of modem humane methods in caring for and treating those convicted of crime, there is no longer any reason for taking into consideration the element of will on the part of those who commit prohibited acts .... Learned counsel's premise suggests a noble conception, and may give promise of a condition of things towards which the humanitarian spirit of the age is tending; yet the stern and awful fact still remains, and is patent to all men, that the status and condition in the eyes of the world, and under the law, of one convicted of crime, is vastly different from that of one simply adjudged insane. We cannot shut our eyes to the fact that the element of punishment is still in our criminal laws. It is evidenced by the words "shall be punished"....

$110 \mathrm{P}$. at 1025 . One concurring opinion responded to the novel argument more abruptly.

The argument that persons are no longer punished for their crimes is illusory and unsound. ... The man who is deprived of his liberty is also punished, and you cannot change the fact by changing the name. . . . But why should we attempt to uphold the statute on humane grounds, when it is an apparent and palpable attempt on the part of the Legislature to punish those whom it fears the tribunal created by the Constitution will acquit?

110 P. at 1027 (Rudkin, C.J., concurring).

This discussion bears an obvious relationship to the issues raised by the AICLC Modern Criminal Law Series General Introduction, discussed infra in text accompanying notes 105 . 112. 
politicians, and members of the public at large who sought to eliminate recourse to the "insanity dodge" via overly susceptible trial juries. Most legal scholars of the post-1910 period both accepted the courts' negative response to such radical reform as a fait accom$p l i$ and adhered to the tenets of the traditional common-law understanding of defendants' rights, political liberty, and the concept of mens rea. At the same time, juristic criticism of the more egregious features of jury trial was intense. The AICLC committee on criminal procedure singled out the delays of voir dire practice and the relatively unfettered discretion that judges allowed juries to exercise. 101 Comparative scholarship contrasting the perceived virtues of the English trial with the excesses of its wayward American offspring became a staple of J.C.L.C. reform-oriented writings. ${ }^{102}$

We can not be certain about this, but for some legal scholars, conventional-sounding trial reform initiatives may have reflected unarticulated deterministic tendencies: proponents of such reforms may have intuitively associated better educated jurors, fewer "technicalities," and the right of the judge to comment on the evidence and to manage proceedings with a firm hand with a form of guiltassessment that represented something close to a mere finding on the question whether the defendant had committed the "act" with which he had been charged. Thereafter, the behaviorist principles of the sentencing stage would dominate proceedings. Some lawyers appear to have adopted a treatment concept of penology; others, especially in the late teens and early twenties, evidenced a more frankly repressive social defense perspective. 103 Most probably countenanced a combination of the two: the least dangerous and most treatable would be rehabilitated and released; hardened of-

101. See, e.g., Proceedings, supra note 88, at 148.

102. For discussion at the 1909 Conference of the appointment of a committee "to inquire into the systems of criminal law and procedure in other countries, particularly Great Britain," see ProceEdings, supra note 88, at 149; see also id. at 188-92. For ensuing writings on the subject, see James W. Gamer, Editorial Comment, 1 J.C.L.C. 1, 4 (1910); John D. Lawson \& Edwin R. Keedy, Criminal Procedure in England, 1 J.C.L.C. 595, 608-11 (1910); James W. Gamer, Editorial Comment: Criminal Procedure in England, 1 J.C.L.C. 682 (1911); James W. Gamer, George Gordon Battle on English Procedure, 2 J.C.L.C. 334, 336 (1911); Edwin R. Keedy, Criminal Law Reform in England and in the United States, 1 PROc. ACAD. POL. Scr. 667,673 (1911).

103. See, eg., Julian P. Alexander, The Philosophy of Punishment, 13 J.C.L.C. 235, 239-40 (1922); Henry W. Ballantine, Criminal Responsibility of the Insane and Feeble Minded, 9 J.C.L.C. 485, 499 (1919) (recommending custodial, not criminal principles, as the latter deal with "definite acts of wrongdoing rather than with general conditions of potential menace"); William G. Hale, Crime: Modern Methods of Prevention, Redemption and Protection, 9 J.C.L.C. 240 (1918); John Alan Hamilton, Making the Punishment Fit the Crime, 12 J.C.L.C. 159, 172-77 (1921) (arguing for combining treatment with social defense, subordinating former to latter). 
fenders would be given opportunities for rehabilitation but would serve longer sentences as a deterrent both to them and to others; incorrigibles would be segregated, perhaps sterilized or even eliminated in the name of the social defense.

One trend that suggests the potential for an increasingly deterministic legal-academic perspective on criminal responsibility - as distinct from penology - was signaled by a brief but important flagship statement that appeared under the auspices of the AICLC. At the National Conference on Criminal Law and Criminology's 1909 meeting, the Conference resolved to establish a series of modern continental criminal-science studies in translation. ${ }^{104}$ The committee charged with selecting and preparing the works was - more so than the Conference itself - dominated by legal academics, all from the "Chicago School." The Chair was John Henry Wigmore, Dean of the Northwestern School of Law and under whose auspices the 1909 Conference had been held; Pound, who shortly after the conference had migrated from Northwestern to the Chicago Law School, and his new colleague there, Ernst Freund, served under Wigmore, as did William Smithers, Secretary of the Comparative Law Bureau of the Philadelphia-based A.B.A., and two non-jurists, Maurice Parmelee, Professor of Sociology at Missouri and Robert Scott, formerly Professor of Political Science at Wisconsin.

The Committee's General Introduction, ${ }^{105}$ which appeared in all of the Series publications until the late teens, was behaviorist in tone and substance. But just how deterministic was it? One can locate a language of negotiation and compromise employed by some among the progressive juristic caste of the 1910s, an approach to the free-will problem that preserved a basis for something like the traditional notion of criminal responsibility. ${ }^{106}$ That language

104. See ProceEdings, supra note 88, at 204 (indicating that the resolution was submitted by Wigmore); $i d$. at 219 (indicating that the resolution was reported by the Committee on Resolutions); id. at 16-17 (indicating that the resolution was adopted by the Conference at its General Session on June 8).

105. General Introduction to the Modern Criminal Science Series, in Raymond SalEILles, The Individualization of Punishment v (Rachel Szold Jastrow trans., 2d French ed. 1911) [hereinafter General Introduction].

106. Perhaps the most significant strain of such thinking was represented by Edward Lindsey, a member of the Pennsylvania Bar (as well as of the American Anthropological Society) and an Associate Editor of the newly founded J.C.L.C. Lindsey published an article in the first volume of the J.C.L.C. in which he stated: "An act of free-will is as much determined by conditions as any other event, but the decisive factor in an act of free-will is not any extraneous circumstance, but the character of the acting person. To state it briefly, we define free-will as a will unimpeded by compulsion." Edward Lindsey, Penal Responsibility and Free Will, 1 J.C.L.C. 695, 696 (1910). Lindsey drew on a recent article by Paul Carus, Person and Personality, 20 Monisr 364 (1910): "Dr. Carus thus clearly shows that we need give up neither our notions of causality nor of freedom of will." Lindsey, supra, at 696. 
alone suggests that we ought to read the General Introduction as a testament to the opacity of all but the most explicit early twentiethcentury juristic ideas regarding criminal responsibility.

The General Introduction began with a rehearsal of the early path of medical science, in which conceptions of the causes of disease and notions of treatment were primitive and undifferentiated. Modern medical science progressed by recognizing the individual characteristics of different diseases. "The same truth," the Committee stated, "is now known about crime; but the understanding and the application of it are just opening upon us."107

The old and still dominant thought is, as to cause, that a crime is caused by the inscrutable moral free will ... in itself the sole and ultimate cause of crime. As to treatment, there still are just two traditional measures, used in varying doses for all kinds of crime and all kinds of persons - jail, or a fine - for death is now employed in rare cases only. 108

The modern approach by contrast would recognize the "natural causes" of crime, the "circumstances which work to produce it in a given case."109

Thus the Committee characterized the prevailing legal view regarding the causes of crime as an absolutist version of the concept of free will, and it appealed instead to the "natural causes" that "work to produce" crime, but quite selfconsciously rejected the notion that crime was a "disease."110 This approach, one might have thought, accommodated the notion that crime was only partly, albeit largely, the product of deterministic "natural causes." Yet the Committee's recommendation for studying the causes of crime seems to leave little scope for human freedom, at least on the part of those who were criminals. It included

all the possible data that can be causes of crime, - the man's heredity, the man's physical and moral make-up, his emotional temperament, the surroundings of his youth, his present home, and other conditions, - all the influencing circumstances. And it means that the effect of different methods of treatment, old or new, for different kinds of men and of causes, must be studied, experimented, and compared. Only in this way can accurate knowledge be reached, and new efficient measures be adopted. ${ }^{111}$

As the committee pointed out in reproachful tones:

107. General Introduction, supra note 105 , at vi.

108. Id.

109. Id. at vii.

110. Id. at vi-vii.

111. Id. at vii. 
All this has been going on in Europe for forty years past, and in limited fields in this country. All the branches of science that can help have been working, - anthropology, medicine, psychology, economics, sociology, philanthropy, penology. The law alone has abstained. The science of law is the one to be served by all this. But the public in general and the legal profession in particular have remained either ignorant of the entire subject or indifferent to the entire scientific movement. And this ignorance or indifference has blocked the way to progress in administration. ${ }^{112}$

About the details of this "progress," though, the General Introduction remained supremely ambiguous, finessing the fact that individualization could operate in the name of benevolent cure, "remedy," or in the name of nonretributive social-defense, "repression."113 Or both - with resulting tensions. Its seeming message of nonresponsibility, reflecting enlightened understanding of human behavior, perhaps presumed the effectiveness of treatment that would reinforce adherence by released offenders to prevailing moral codes. Then, too, juristic acceptance of the principle of individualization might have assumed what some scientists - including many penologists - openly proclaimed: that many offenders would be found untreatable and should be kept permanently in isolation from the public. Equally, however, its very message might undermine the social defense by preaching a sermon that would weaken the resolve of potential offenders. And its focus on the offender rather than society at large might lead to early release of "cured" offenders and thus detract from the general deterrent capacity of criminal administration. Might not a retreat from harsh punishment - even were it replaced with "benign" long-term incarceration - itself be a potential "cause" of criminal behavior?

Over the course of the Progressive Era, these problems increasingly challenged the rapprochement of 1909. In part they resulted from the Great War and its immediate aftermath, which saw heightened concern with crime and national security. But they were also the product of the intensive study by psychologists and penologists of incarcerated offenders; the results of such studies, allegedly revealing large numbers of "insane" and "feeble-minded," held important implications for traditional approaches to guilt assessment. ${ }^{114}$ The growing importance of psychiatry further intensified conflict between lawyers and behaviorists. Even those law-

112. Id. (emphasis added).

113. See infra text accompanying note 367.

114. See, e.g., Kirchwey, supra note 86. Kirchwey had been Dean of Columbia Law School, then warden at Sing Sing. In his 1918 AICLC "President's Address," Kirchwey told his audience about Dr. Bernard Glueck's studies in Sing Sing: 
yers disposed to view criminal behavior as determined increasingly concluded that the psychiatric school undermined the social defense. For the most part these increasing tensions remained at bay until the mid-1920s, which is itself testament to the strength of the Progressives' belief in the solubility of social problems.

In fact, these old tensions lay at the heart of Progressivism, the ambiguities implicit in "treatment," "social reform," and "efficiency." In its own ambiguity the General Introduction papered over the competing strains of Progressivism, as represented by the varying perspectives of individual criminal justice scholars. The General Introduction was, after all, written by a committee. More to the point, it was written by a legal culture at war with itself, as all legal cultures infected by a "science" that implies strongly mitigated criminal responsibility are likely to be.

The deterministic rhetoric of the Progressive Era, then, made inroads on the presumption of human free will in the criminal context, portraying will and context in constant competition. But an examination of contemporary noncriminal jurisprudence reveals determinism's tenuous grip on American legal thought. The contrast between criminal and noncriminal jurisprudence lay side-byside with the more fundamental relationship I am sketching throughout this essay between the criminal justice perspectives of social and behavioral scientists on the one hand and legal scholars on the other. As noted, deterministic criminal jurisprudence had originally come from outside the legal academy and had penetrated it in more than a modest way, while accommodating a residuum of the traditional concept of mens rea and a freedom-affirming view of the rehabilitated offender. With respect to noncriminal jurisprudence, the implications of deterministic thought seem to have played out rather differently. In that context, a more conventional

\footnotetext{
You who have made yourself familiar with his writings will recall that Dr. Glueck's conclusions based upon the consecutive study of 660 admissions, without any selection or discrimination, that of the population of Sing Sing prison apparently nearly 60 per cent., some 59 per cent., were not normal, were either abnormal or subnormal, half of them probably mentally defective in such degree as to be practically irresponsible, twelve years of age and under mentally; the other half divided unevenly between those whom the psychiatrist classes as psychopathic and those whom he classes as insane, were all of them either continuously or occasionally quite irresponsible for their acts. In other words - let us be conservative - upwards of one-half of the population of Sing Sing prison is made up of persons who are non compos. They should not be held responsible by the law for their acts on the presumed ground of their capacity to choose between the right and the wrong....
}

Id. at 333-34. As to most of the remaining inmates, Kirchwey reported on the basis of his own "personal observation... during which [time] I was connected in a responsible way with Sing Sing," id. at 334, that most were "young fellows who have from childhood, babyhood in many cases, led neglected and then vicious and then criminal lives," id. at 335. 
message of Progressivism held sway, one that largely avoided the tensions and darker themes of Progressive-Era criminal justice. Here, the vanguard of the new, anticlassical jurisprudence, from Pound's early sociological jurisprudence down to the realism of the 1920 s and early 1930 s, more comfortably adopted a relativistic approach to human autonomy. As in criminal jurisprudential writing, the enemy was an exaggerated view of human autonomy. In the context of private law, however, jurists conceived the problem in light of the perceived imbalances in bargaining power in the marketplace and in society at large. Given this crucial difference in setting, the remedy, reflected in writings both on private law and on the main currents of constitutional doctrine, was an adjustment of the balance of power between individuals or between individuals and collective entities. Noncriminal jurisprudence focused, then as now, more directly on the problem of equality of opportunity than on the problem of human freedom per se. ${ }^{115}$

We should note at the outset that the modern critique of criminal law in the main preceded that of private law. Although the latter, too, had roots in the late nineteenth century, ${ }^{116}$ it did not become widespread until the 1910 s and 20 s, by which time the late nineteenth-century behavioral and medical science attack on the principles that underlay criminal law had already led to movements for juvenile justice and reform in penology, intense conflict regarding the insanity test, and some tellingly defensive commentary regarding the concept of mens rea. The critique of private law, by

115. The point I want most to make is that a gentler - and perhaps the true - spirit of Progressivism informed the early private-law-based critique of classical jurisprudence. Like most of the reform projects of the day, this side of sociological jurisprudence called for direct confrontation of the facts of social existence and a flexible, efficient use and manipulation of the 'environment (both physical and mental) to make good on America's promise of (relatively) equal opportunity for personal autonomy and development. Like other programs, it viewed governmental institutions as instrumental, recognizing their creative, shaping power; it rationalized this reforming role for institutions as a necessary counter-force to those aspects of social and economic life that distorted, corrupted, or suppressed fundamental American values. This mainstream Progressivism - and sociological jurisprudence as well - was founded on a soft, albeit definite form of behaviorism. It recognized the fragility of the human will and the limitations on human autonomy in a complex industrial society. In general, and in the context of private law, Progressivism emerged as the first wave of modern revisionism; it was dedicated to using the new sciences as instruments for recovering the old values, to optimistic and only very partial exploitation of the techniques of science, and to systemic repression of the new scientists' bleak implicit message. The drift within Progressivism toward a harsher, more deterministic social control ethic - as in the case of some forms of penology - was a drift out of the mainstream, perhaps in its most "progressive" forms, out of Progressivism altogether. For an excellent treatment of Progressivism (which is not responsible for the tenor of my own brief account), see Daniel T. Rodgers, In Search of Progressivism, 10 Rev. IN AM. Hist. 113 (1982).

116. See Morton J. Horwitz, The Transformation of American Law, 1870-1960: The Crisis of Legal ORTHOdOXY 33-143 (1992). 
contrast, began early but matured slowly, largely out of attempts to limit the reach of private law concepts as they were embedded in constitutional law. In its origins, this critique of private law bears significant relation to the attack on traditional concepts of criminal responsibility. But outside of criminal law, the critique of human freedom was always somewhat muted and emerged more clearly from economics, sociology, and political science than from behavioral and medical science. ${ }^{117}$

The noncriminal classical jurisprudence of the late nineteenth century was, of course, more epiphenomenal than appears from conventional historical accounts. It gave heightened emphasis to general tendencies of mind, however, and it provided a target for critics, who readily gave it a prominence and importance it otherwise might not have had. Today we see classical jurisprudence through the lens of, among others, Holmes, who exaggerated formalism in order to set off his own deeply skeptical views, ${ }^{118}$ and Pound, who by nature simplified matters in order to think more clearly about them. ${ }^{119}$ In this sense, it was Pound who spoke the language of the law: His prewar sociological jurisprudence evidenced a refreshing candor about the conventional legal thought of his day. If he exaggerated the typicality of classical jurisprudence, he aptly epitomized its main thrust and nicely mocked the often unstated assumptions of fin de siècle jurists and legal academics. ${ }^{120}$ Pound styled his foray "sociological jurisprudence," and indeed had already established himself as the leading exponent of the subject;

117. For an important account of late-nineteenth and early-twentieth-century developments regarding deterministic perspectives in the social sciences, see THOMAS L. HASKELL, The Emergence of Professional Social Science: The American Soctal Science AsSOCIATION AND THE NINETEENTH-CENTURY CRISIS OF AuthorTty 234-56 (1977). My point here is that those private-law jurists who were influenced by developments in the social sciences seem not to have moved beyond episodic concern with aspects of environmental causation to holistic conclusions of a deterministic sort.

118. See Mathias W. Reimann, Holmes's Common Law and German Legal Science, in The LeGacy of Oltver Wendell Holmes, Jr. 72 (Robert W. Gordon ed., 1992).

119. Pound was, nonetheless, a leamed, wise, and important legal scholar. His historical and philosophical writings were overly schematic, but his reach was impressive - even extraordinary - and he used his ability to create schemas and taxonomies to good advantage. For accounts of Pound, see JAMEs E. HERGET, AMERICAN JURISPRUDENCE, 1870-1970, at 164-70 (1990); PAUl SAYre, The LIFe of RosCoe Pound 312-80 (1948); Wigdor, supra note 88; N.E.H. Hull, Reconstructing the Origins of Realistic Jurisprudence: A Prequel to the Llewellyn-Pound Exchange over Legal Realism, 1989 Duxe L.J. 1302, 1306-11; G. Edward White, From Sociological Jurisprudence to Realism: Jurisprudence and Social Change in Early Twentieth-Century America, 58 VA. L. REv. 999, 1004-12 (1972).

120. This tendency to exaggerate and this critical insight characterized Pound's early criminal-law efforts, though - as we shall see - in the domain of criminal law more radical strains of thought infected even his early writing. 
his 1908-09 essays, Mechanical Jurisprudence ${ }^{121}$ and Liberty of Contract, ${ }^{122}$ lay at the cutting edge of the legal-academic Progressive critique of the formalism and the exaggerated view of human autonomy prevalent in noncriminal classical jurisprudence. $\mathrm{He}$ attacked on two fronts: first on the obsession with formal rights at the constitutional level that, as he saw it, rationalized the striking down of social legislation on grounds that such legislation limited autonomy in the domains of property and contract; and second, on the Langdellian formalism in private law that gave unrealistic primacy to the ideal of autonomy.

The seemingly unlikely fit between the quasi-scientific reasoning processes of Langdellian scholarship and the quasi-religious quality of the fundamental rights that some jurists and scholars found at the heart of both the Constitution and the common law is intriguing. ${ }^{123}$ In fact, these natural rights had lost much of their traditional religious nature, and had been shrouded, instead, in a kind of secular fundamentalism. ${ }^{124}$ These jurists and scholars came to see the rights to liberty, property, and freedom of contract as natural to man, in the sense of fitting his own purposes and inclinations. To study man and his development in historical context, to consider the purposes of the state and civic order, to ponder the irreducible ideas of the common law: all of these endeavors led many jurists to see human nature and human potential as inextricably bound up with the phenomena of human reason, human autonomy, and enjoyment of the fruits of the free exercise of human faculties. For

121. Roscoe Pound, Mechanical Jurisprudence, 8 Colum. L. Rev. 605 (1908).

122. Roscoe Pound, Liberty of Contract, 18 YALE L.J. 454 (1909).

123. See Grant GiLmore, The Ages of American Law 41-67 (1977); see also William E. Nelson, The Impact of the Antislavery Movement upon Styles of Judicial Reasoning in Nineteenth-Century America, 87 HaRV. L. REv. 513, 560-66 (1974). A large body of scholarship deals with the "formal" or "classical" jurisprudence of the late nineteenth century. Not all historians give as much emphasis to "legal science" as do Gilmore and Nelson; nor do all characterize the period as an "Age of Faith." For a recent account of "classical legal thought," see HoRwrIz, supra note 116, at 9-31. Horwitz draws upon Duncan Kennedy, Towards an Understanding of Legal Consciousness: The Case of Classical Legal Thought in America, 1850-1940, 3 Res. LAw \& Soc. 3 (1980). Daniel R. Emst discusses the KennedyHorwitz approach in The Critical Tradition in the Writing of American Legal History, 102 YALE L.J. 1019 (1993) (book review).

124. See Nelson, supra note 123, at 555-58. Horwitz argues that Progressive jurists "bent on de-legitimating the claimed autonomy of orthodox legal reasoning" charged classical jurists with basing decisions on natural law principles, whereas classical jurists "felt . . . constrained by their own positivistic framework." HoRwIT, supra note 116, at 159. According to Horwitz "natural rights discourse structured legal argument by suggesting starting points, background assumptions, presumptions, or first principles in the law." Id. at 158. See Roscoe Pound, The Need of a Sociological Jurisprudence, 19 GREEN BAG 607, 612-13 (1907), for examples of the fundamentalist concepts of property rights to which he objected, and which he believed were passing out of favor, despite their continued articulation in legal texts and judicial opinions. 
many, the scientific study of man demonstrated that these phenomena were facts of life, natural to man, good because fitting and tested over time.

The argument was not entirely tautological; it served larger purposes. Some found Herbert Spencer's Social Darwinism plausible: Human development and competition accorded with nature's inevitable sorting out of the fit from the unfit, so that interference with natural processes was socially regressive. Others may have continued to believe - or to say - that God intended man to be an autonomous and self-realizing being. Still others, no doubt, saw social and economic well-being and productivity as the beneficiaries of this conception of human nature and activity. Most jurists indulged a combination of these notions, a curious blend that made classical jurisprudence complicated and compelling. ${ }^{125}$

By Pound's day this world view had encountered searching criticism for several decades from political scientists, sociologists, and historians, among others; most of the attack had not been aimed at the law, as such.126 Legal scholars enjoyed the luxury of distilling and crystallizing the ideas of an earlier generation of thinkers from fields that - unbeknownst to most lawyers - were undergoing major transformations. Pound contributed to scholarship by deploying the new criticism in his attack on classical formalism. In reality, Pound countered, man was a social being; his actual autonomy was relative to his social context; any fair-minded attempt to accord all people some semblance of their basic rights required constant attention to their social situation. As Pound saw it, legal reasoning and legal categories had come to mirror subjective desire for personal autonomy either out of jurists' wishful thinking or in their service to the interests of those whose positions endowed them with power to exercise real autonomy in relation to others, whose own freedom was thereby rendered a fiction. ${ }^{127}$

That Pound wrote extensively in both noncriminal and criminal jurisprudence made him a rare bird in his day. It is perhaps instructive that he brought differing emphases to bear on his concern

125. For a valuable discussion of the complexities of "Victorian Legal Thought," see Ernst, supra note 123 , at 1037-46.

126. See generally HASKeli, supra note 117 ; JAMES T. KLOPPENBERG, UNCERTAIN VIC-

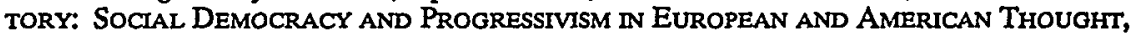
1870-1920 (1986); Dorotriy Ross, The OrIGINS of AMErican Social SCIENCE 53-142 (1991); Morton White, Social Thought in America: The Revolt Against FormalISM 11-106 (1957). White focuses on the law at pages 59-75, using Holmes as a link between the larger, nonjuristic movements and the beginning of a juristic critique.

127. Many of Pound's early writings sounded one or another of these themes. See Pound, supra note 122; see also Pound, supra note 124. 
about human freedom in the two domains. In his criminal law writings, to which scholars have paid scant attention, Pound gave significantly greater emphasis to his skepticism regarding the concept of free will - which in itself says something important about the difference between the two fields of concern. Yet even in his criminal justice studies, at the cost of coherence - and by skating on the surface - Pound fashioned a relatively untroubled accommodation of the free-will critique; he envisioned fundamental change over the long term and settled, in the short run, for reforms that mixed discordant elements.

Pound's criminal law writings, from almost the fin de siècle down to his 1923 Colver lectures - delivered at Brown University and published, with only slight revisions, seven years later as Criminal Justice in America ${ }^{128}$ - repay consideration because they reflect the thinking of a moderate realist of pronounced social-science bent, a juristic Progressive of large vision. Pound's criminal law jurisprudence - as it evolved across the Progressive Era - reveals those understandings of history, politics, and society which reflected the tensions that one of the most influential and widely read earlytwentieth-century academic common lawyers experienced regarding the interrelated problems of political liberty and human free will. In retracing Pound's steps over two decades, we witness the final - yet, as we shall see, inconclusive - act of the fin de siècle drama with which we began.

\section{B.}

Pound, like Speranza, was a lawyer; but whereas Speranza had fully embraced a version of the behavioral science theory of his day, Pound, though trained originally as a botanist, remained a jurist through and through. But Pound - here a true Progressive - resisted the idea of an unbridgeable gulf between the law and science, which he believed could be made to serve law's ends. If Pound perceived the most intractable problems that the new science

128. Roscoe Pound, Criminal Justice in America (1930). In the Preface (dated November 7, 1929), Pound stated:

These lectures have been written out from the notes used at the time of their delivery

(1923). In the years which have intervened much has happened, but little, I think, to change the main lines of the picture or important details. Occasionally a reference to subsequent events has been interpolated; but with these few exceptions the lectures speak from the date of their delivery and represent what I then thought and said. This caution seems expedient lest they should appear to pass a present judgment on what I am now required to look into more deeply.

Id. at Preface. All discussion in this Essay of Pound's 1923 lectures refers to the 1930 published form. 
presented, he chose to avert his gaze; for the most part, he tended to write as though they did not exist. ${ }^{129}$

Like Speranza, Pound believed that the Anglo-American tradition had spawned a concept of rights that was artificial but highly useful as a brake on the overweening power of the state. Indeed, Pound produced a minihistory, from classical times forward, into which the Anglo-American experience neatly fit. The history of the West exemplified a cyclical pattern: Periods characterized by the unrestrained and arbitrary power of the state were followed by periods that saw an accent on the rights of the individual. ${ }^{130}$ Nineteenth-century America, in the second part of the cycle, celebrated a concept of natural rights founded, in part, upon a reception of English resistance theory, itself a reaction against the royalist hegemony of the preceding centuries. Such ideas accorded well with our own early political and social experience, or what Pound termed our "pioneer attitude":131 freedom-loving Americans manifesting individualism in their desire to govern themselves, to take law into their own hands, to shake off the yoke of commonlaw formalities. There was some tension between rights ideology in its English and American guises, but taken together they could blend into a unitary, individualist, natural-rights tradition.

For Speranza, the century's turn was the new age of behavioral science, whose methods and concepts directly countered the free-

129. This is at least mainly the case, as my study of Pound will suggest. See also Sheldon Glueck, A Memoir in Appreciation of the Dean of American Legal Scholars, in ROSCOE PoUNd AND CRIMINAL JUSTICE 1 (Sheldon Glueck ed., 1965). Glueck provides a comprehensive overview of Pound's criminal justice writings, covering many areas that I do not treat. He gives relatively little space to the areas of criminal jurisprudence I am concemed with, however, and he does not provide a detailed or interpretive account of the particular problems I address. He correctly notes that Pound paid little attention to the substantive law, noting that "he left to others the baffling issue of mixing the oil of ethically based 'responsibility' with the water of science-influenced determinism." Id. at 23. He also pointed out that "[i]n 1960, Pound was still insisting that 'Nowhere in the legal order is rethinking of fundamental problems more needed than in our criminal law." "Id. at 22. For a more general discussion of Pound, see id. at 19-23. He also summarizes some of Pound's views on legal rules, discretion, and individualization. See id. at 30-36. For two other discussions of the general characteristics of Pound's approach to criminal justice, see John Griffiths, Ideology in Criminal Procedure, or, A Third "Model" of the Criminal Process, 79 YaLE L.J. 359, 391-95 (1970); Louis H. Masotti \& Michael A. Weinstein, Theory and Application of Pound's Sociological Jurisprudence: Crime Prevention or Control?, 2 ProspeCtus 431 (1969).

130. Pound's habit of providing a schematic and loose-fitting historical periodization for the origins of the ideas he addressed in what were predominantly philosophical, rather than historical, commentaries traces back to his earliest articles. See, e.g., Roscoe Pound, Do We Need a Philosophy of Law?, 5 Colum. L. Rev. 339 (1905); Roscoe Pound, A New School of Jurists, 4 U. Stud. OF TrIE U. OF NEB. 249 (1904); Roscoe Pound, The Spirit of the Common Law, 18 GREEN BAG 17 (1906). Much of Pound's later work repeated and elaborated upon that historical framework.

131. Pound, supra note 128 , at 132. 
will-based ideas of the nineteenth century. For Pound, at least well into the $1920 \mathrm{~s}$, the new age was the age of collectivism; the demands of modern life made the nineteenth-century concept of individualism, to put it mildly, an inconvenience. But Pound, unlike Speranza, looked mainly to sociology and political science, rather than to behavioral and medical science, perhaps as a result of his early focus on noncriminal law. Pound understood that behavioral and medical scientists had attacked - he came to say they had "routed" - the concept of free will in criminal law, but to that fact, from which, as we shall see, he never drew truly deep or disturbing conclusions, he paid only intermittent and relatively minor attention. It did not blunt his optimistic belief that law and science were ultimately headed in the same direction. For Pound, scientific notions were functional, instructive, the keys to administrative efficiency - they might well instruct judges regarding the effects of their decisions. Science was above all a means to mediate between the individual and the collective order. The new learning made plain that the reification of rights in common-law theory, as well in important instances - as their constitutionalization, threatened paralysis, and threatened to undermine the position of those individuals whose social and economic circumstances rendered their possession of those "rights" a cruel artifice. ${ }^{132}$ This is, of course, where his noncriminal-law critiques of "mechanical" jurisprudence and liberty of contract fit into his historical analysis. Not that Pound was entirely sanguine about the new collectivist age for which he prescribed modification of the judge's approach to the common law. Once again, as he commented in 1921 in The Future of the Criminal Law, ${ }^{133}$ the age witnessed a drift back in the direction of unrestrained authority; once again, insistence on "individual freedom" and on individual rights, in the form of the procedural guarantees of the criminal law, had to be maintained - up to a point, and in order to achieve the proper balance.

What, then, of the new behavioral science? Had Pound missed the deeper implications of that movement altogether? As early as 1909 , Pound seemingly had endorsed criminologists' critique of the concept of free will; in that year - still early in his career - Pound reflected with considerable maturity on the relationship between science and law and set forth a position against which his later writings on criminal jurisprudence must be read. But his thinking was,

132. Pound, supra note 122.

133. Roscoe Pound, The Future of the Criminal Law, 21 Colum. L. REv. 1 (1921). 
and remained, profoundly contradictory. He repeatedly rejected the essentials of what he called the "orthodox" common-law theory of crime, or what he believed had come to be so in eighteenth- and nineteenth-century America: the retributive theory, the necessary joinder of act and intent, and the notion that the offender had possessed free will. This critique has the feel of a mantra, though, intoned but not elaborated upon or explained. Pound never spelled out an alternative system of criminal justice. He was aware that dismantling the orthodox approach posed dangers for political liberty, and argued for retaining the safeguards of criminal procedure.

In large part, it must be said, Pound deferred problems to the future, seeking temporary refuge in the bifurcation of trial and penology. Too much the jurist to follow the implications of the free will critique to their logical ends, he adopted a middling position, one that recognized offenders were at least largely the product of social or other determining conditions, but that sought to accommodate this perspective within the existing system. He urged a deemphasis of the concept of individualism and, above all, a reform of legal institutions. That reform, together with a gradual erosion of the doctrine and practice of retribution, would, Pound thought, cure the worst infirmities of criminal law and its administration, and allow for retention of those necessary protections against the state. If tensions remained, they would disappear in time, as law accommodated itself to developments in science. The underlying theory of crime would itself eventually be reformed - the assumption that the offender possessed a truly free will would disappear - but the rest of the criminal law would evolve from reforms already under way. The administration of criminal justice would change, perhaps dramatically, but it would remain in its essentials the administration of justice by jurists and as jurists understood it.

The "logic" of Pound's reformist position was clear in 1909. Before examining Pound's remarks in that year, I should note that in a series of articles from 1905 to 1908, Pound had already marked out a distinctive position on the state of criminal justice administration in America. Pound's earliest criminal law writings reveal the influence of his student days and of his early teaching and practice in Nebraska, where he was attentive to problems of procedure that he always understood as more than matters of machinery. $\mathrm{He}$ quickly saw the interplay between judge and jury and the manner in which each filled out the law on the books. ${ }^{134}$ From his legal educa- 
tion at Harvard under the tutelage of John Chipman Gray he absorbed an appreciation of the judge's lawmaking role; ${ }^{135}$ in his Nebraska professorial capacity he developed his understanding of the social importance of creative exploitation of that role through exposure to, among others, the prominent sociologist Edward Ross. ${ }^{136}$ Frontline practice, mostly in private-law areas, taught him the subtleties of jury-based lawfinding.

Pound's 1903 Outlines of Jurisprudence ${ }^{137}$ reflects both his interest in Holland's Elements of Jurisprudence ${ }^{138}$ and, perhaps more importantly, his attraction to Sheldon Amos's discourse on criminal law. ${ }^{139}$ Amos contributed a modern perspective on criminal jurisprudence, including elements that folded over easily into the embryonic sociological jurisprudence which Pound borrowed, both directly and via others, from fashionable German legal scholarship. ${ }^{140}$ But Amos influenced Pound in other ways as well: In lengthy passages that Pound prescribed for his students, ${ }^{141}$ Amos preached the necessity of a fit between the mandate and theory of the law and deep-seated social norms. Nowhere was this more important than in criminal law. As Pound saw it, sometimes this meant legal reform could proceed only so fast; sometimes it meant devices were required to correct for the inflexibility of law. But the attention to the necessity to create a "fit" was always present. This strain of thought ran through Pound's publications during his $\mathrm{Ne}$ braska days - down to 1907 - and thereafter, both at Northwestern until 1909, where Dean Wigmore encouraged his interest in criminal justice reform scholarship, and at Chicago in 1909.142 It

\section{Id. at 89.}

136. Id. at 111-13.

137. Roscoe Pound, OUtLines of Lectures on Jurisprudence, ChIEFLy From the ANALYTICAL STANDPOINT (1903).

138. See id. at 66 (discussing Thomas Erskine Holland, The Elements of JurispruDENCE (Oxford, Clarendon 1880)).

139. See Pound, supra note 137, at 66 (regarding SHELdon Amos, ScIENCE OF LAw 228$89(1880))$.

140. See James E. Herget, The Influence of German Thought on American Jurisprudence, 1880-1918, in THE RECEPTION OF CONTINENTAL IDEAS IN THE COMMON LAW WORLD, 18201920, at 203, 215, 221-23 (Mathias Reimann ed., 1993).

141. Pound, supra note 137, at 66.

142. See Paul D. Carrington, The Missionary Diocese of Chicago, 44 J. Legal Educ. 467, 503-11 (1994). Carrington notes that after Pound's acclaimed 1906 address to the annual meeting of the American Bar Association, see Roscoe Pound, The Causes of Popular Dissatisfaction with the Administration of Justice, in REPORT OF THE TWENTY-NINTH ANNUAI Meetino of tHE AMERICAN BAR Association (1906), Wigmore enticed Pound to leave his post at Nebraska and come to Northwestern. At Northwestern, Pound organized the 1909 national conference on criminal law and criminology. Carrington, supra, at 507. Pound was active as well outside the law school, having joined various interdisciplinary organizations. He became a member of the Juvenile Court Committee in which he worked closely with Hull 
followed him east to Harvard in 1910 and, in one fashion or another, played a critical conditioning role in almost everything he thought and wrote about the criminal law down to his final days in the mid-1960s in Langdell Hall.

To his earliest criminal law work, then, Pound brought the same elements that have been studied by scholars of his noncriminal jurisprudence. The extraction of Pound's specific ideas on criminal jurisprudence from his more general frameworks of sociological jurisprudence, organicism, instrumentalism, and Progressivism works some scholarly injustice, but helps in the task of retracing Pound's thinking about the role of freedom - free will and political liberty - in American criminal justice. In any case, one has to sneak up on the issue of freedom in Pound, for that, in a sense, is the route he himself took. He rarely focused on the issue systematically: Rather, he most often resorted to anecdotal accounts of actual onthe-ground-experience to make his points about the role of the ideal of human agency in the description and assessment of the law in practice. From a historically and sociologically informed empiricism - one in which the issue of freedom, first political liberty, later human free will, played an increasingly important role Pound drew his observations and prescriptions, too many to detail here. My story of Pound's odyssey is only one of many that might be told.

From his first essay in criminal jurisprudence in 1905, Pound associated popular discontent concerning both private and criminal law with the American adversary system's "exaggerated respect for the individual":143 "We strive in every way to restrain the trial judge and to insure the individual litigants a fair fight, unhampered by mere considerations of justice."144 This cost time, money, and

House's Jane Addams and with Emst Freund, and became involved in the Social Science Club, where he collaborated with Albion Woodbury Small, the prominent sociologist. Id. at 508. In 1909, much to Wigmore's dismay, Pound accepted a position at the University of Chicago Law School, probably in order to gain greater access to the likes of Dewey, Small, Freund, and Addams.

Pound put these credentials and connections to good use. He leapt into the vanguard of the national campaign for judicial law reform, arguing for "the authority of courts to make their own rules of procedure, for the simplification of court organization to prevent needless hassling of jurisdictional issues, for the harmless error principle, and for the eradication of needless technicality." Id. at 509.

143. Roscoe Pound, Do We Need a Philosophy of Law?, 5 CoLum. L. Rev. 339, 346-47 (1905).

144. Id. For Pound's classic description of this "sporting theory" of justice in private-law cases, see Pound, supra note 142, at 404-05. Pound drew here, in this famously iconoclastic address, upon Wigmore. See 1A JoHn Henry Wramore, Evidence In TrIals at Common LAW $\S 57$ (Peter Tillers rev., 1983). Thirty years later, Wigmore described the shocked and angry reaction of many members of the American Bar Association in attendance at the meet- 
public patience: "[O]ne may sometimes wonder whether lynchings are not our modern bills of pains and penalties."145

In the years 1905-1907, Pound trained his critical gaze on the impact of "individualism" on the substantive law and on the gulf between the law and contemporary attitudes, a gulf widened by a period of dramatic social change which spawned diverse interests and conflicting groups. The existing law could no longer achieve "justice," which is to say, "adjust the relations of every man with his fellows so as to accord with the moral sense of the community."146 When law failed, "The individual looks at cases one by one and measures them by his individual sense of right and wrong."147 Pound's remedy for this problem appeared initially in his 1907 article, The Need of a Sociological Jurisprudence. ${ }^{148}$ The article asserted that a widespread disrespect for law engendered "appeals to the so-called unwritten law . . . appeals from the clear and settled law to the individual feelings of the citizen . ..."149 Pound attributed these antinomian attitudes to the social upheavals of a period of transition, ${ }^{150}$ an optimistic note that was repeated in 1908 when Pound claimed that:

[T] his friction between ethical and sociological theory and legal theory is a temporary phenomenon. When the shifting to the new standard of justice is accomplished, when education and the labors of sociologists have brought about the internal conditions of life measured by reason, the judicial machine will run normally once more and law will speedily take care of the external conditions. ${ }^{151}$

ing in St. Paul, Minnesota. John H. Wigmore, Roscoe Pound's St. Paul Address of 1906, 20 J. AM. JudicatuRE Socy. 176 (1937). Belknap aptly recounts the incident in MicHAL R. BEL KNAP, TO IMPROVE the AdMINISTRATION OF JUSTICE: A History OF tHE AMERICAN JUdiCATURE SOCIETY 9-12 (1992). Belknap notes: "Even the ABA, where the opposition to Pound's views was probably never as great as Wigmore believed, soon acknowledged the validity of many of [Pound's] criticisms." Id. at 11. See also N.E.H. Hull, Restatement and Reform: A New Perspective on the Origins of the American Law Institute, 8 LAW \& HisT. REv. 55, $56-58$ (1990).

145. Pound, supra note 143 , at 348 . Pound here adopted a widely shared view of the relationship between lynching and the delays associated with the regular judicial process. See Richard MaXwell Brown, Strain of Violence: Historical Studies of AMERICAN VIOLENCE AND VIGILANTISM 144-79 (1975).

146. Pound, supra note 142, at 399.

147. Id.

148. Pound, supra note 124.

149. Id. at 607.

150. See id.

151. Roscoe Pound, Enforcement of Law, 20 GreEn BAG 401, 403 (1908). Here Pound stated: "Today moralists and sociologists are taking another view of justice. Not liberation of energies but satisfaction of wants is made the central point. They are defining social justice. They are teaching that while equality is a concept of individualization, justice is a concept of co-ordination." Id. (footnote omitted). 
In the meantime, of course, "The necessarily mechanical operation of legal rules is an inherent difficulty in the administration of [criminal] justice."152 The result of this "temporary" dysfunction: "Juries are conscious that the law in some way does not accord with the general sense of right, and find verdicts which are crude attempts to vindicate half-grasped conceptions of social justice."153 This conception of the jury was an important theme for Pound. In his earliest articles, he often situated the jury as a progressive, mediating institution, both in civil and in criminal cases. Often - especially on the criminal side - but not without ambivalence.

That ambivalence, at best, was a hallmark of Pound's most comprehensive prewar study of criminal administration, Inherent and Acquired Difficulties in the Administration of Punitive Justice, a speech delivered to the American Political Science Association in December, 1907, and published the following year. ${ }^{154}$ Therein Pound referred to the "extravagant powers conceded to juries"; 155 and to "the excessive ... powers which we delegate to juries or permit them to usurp."156 But in commenting upon "our habits of piecemeal legislation [that] make criminal codes absurd from want of proportion," Pound conceded: "It is no wonder that the common sense of jurors leads them to take the law into their own hands in such a situation."157 Pound's ambivalence toward the jury reflected the complexity of his now almost fully developed analysis of what had gone wrong with criminal justice administration. It traced to what he saw as the causes of a "[d]issatisfaction with criminal law and its administration [that] today is world-wide" and that in America focused mainly on "inefficiency" rather than injustice. 158 That "inefficiency" Pound detailed with respect to both "inherent" and "acquired" difficulties, covering almost every aspect of criminal justice administration.

Only several aspects of Pound's well-known disquisition need to detain us. First, Pound noted that the "public desire for vengeance" was deep-seated and that juristic commentators were divided between those who sided with "moralists or sociologists" in their con-

152. Id. at 406 .

153. Id. at 403.

154. Roscoe Pound, Inherent and Acquired Difficulties in the Administration of Punitive Justice, 4 Proc. AM. Pol. Scr. Assn. 222 (1908).

155. Id. at 225.

156. Id. at $235-36$.

157. Id. at 232.

158. Id. at 223. 
demnation of it and those who regarded it "as a legitimate as well as practically necessary end." 159 Pound conceded that "to prevent self-help and to meet the demands of the moral sentiment of the community, it is necessary to retain much that is purely retributive."160 But, he added, this same emotion played havoc with the administration of criminal justice, producing serious inconsistencies:

One jury is stern, applies the revenge theory as like as not; another is soft-hearted. And so the fact that we are not all agreed, nor all of us in all our moods, upon the end of punishment, infects both legislation and administration with uncertainty, inconsistency, and in consequence, inefficiency. ${ }^{161}$

Second, these insights went to the heart of Pound's account indeed, they governed it perhaps more than he himself realized. They bridged "inherent difficulties," such as the desire for revenge, the problems of controlling the inevitable need for discretion and the ties between criminal law and politics with "acquired difficulties," which were at once embedded in our inherited common-law adversary system and given a special turn by the American historical experience. Americans' attraction to natural law theory and ultra-individualism flowed from our resistance to English legal and political oppression. This latter resistance to governing magistrates exacerbated common law "jealousy" of legislation, procedural complexity and delays, and, most important, the exaltation of juries over judges that interfered with efficient, accurate, and consistent administration of criminal justice. 162 Pound understood that the ("inherent") retributive theory was related to the ("acquired") unbridled powers of the American jury, but he sketched the essentials of that relationship in only vague terms. We must abandon the retributive theory, he now counseled - adding almost derisively that it was "taught as among the fundamenta of law."163 He predicted in his concluding passage that "[g]eneral improvement will come through better general education in sociology, leading the public to abandon the retributive idea and the man in the street to desist from his demand for revenge ...."164

159. Id. at 226.

160. Id. at 227.

161. Id. (emphasis added). As my emphasis is meant to indicate, I read this statement as poignant and self-revelatory, not as one of Pound's commonplace observations. I sense that it reflects a life-long personal perspective that Pound normally did not allow to rise to the surface in his writing.

162. Id. at 230-35.

163. Id. at 234.

164. Id. at 239. 
Third, although Pound had begun by balancing the sociologist's criticism of the desire for revenge and some jurists' recognition of the virtues of that deep human emotion, and had ended with a call for repudiation of the "retributive theory," he remained vague about what that "theory" involved. As to will theory - the conventional doctrine of mens rea - Pound had remained almost silent. He recognized that the requirement of intent flowed from the retributive theory, which he opposed; however, his noting the importance of the movement to eliminate intent as an element in many statutory offenses ${ }^{165}$ seems to be essentially instrumental. The intent requirement forestalled attempts at rational social control. If Pound believed it was premised on a false conception of human behavior, he hadn't said so. Pound may have accepted the criminologist's view that "crime [was] a disease," "166 and assumed his audience would understand all of the implications of that view; but his chief point seems to have been that sociological and criminological education would stem the desire for revenge and so make possible rational and efficient procedures for determination of responsibility and intelligent and effective means of reform of convicted offenders. Pound sought a rational, sociologically informed ordering between liberty and social needs, but not - at least not explicitly - an entire rejection of the conventional notion of mens rea or a retreat to a system of criminal justice premised upon a deterministic theory of the social defense. It was, all and all, an elaborate, even beautiful construct, evasive on the critical issue of underlying premises as, one might suggest, any socially acceptable juristic account of criminal justice must inevitably be.

Finally, Pound's call for a reduction in the powers of the criminal trial jury requires further comment. Pound opposed the official law-finding doctrine where "such absurd legislation" continued to exist and he railed against the practice of allowing juries to set punishments: "They will be lawless enough without encouragement,"

165. Id. at 234.

166. Pound's statement here was that "[t]he criminologist complains that ... whereas he has 'demonstrated positively that crime is a disease,' the law persistently deals with the criminal as a normal person." Id. at 222 (quoting BoIEs, supra note 57, at 90). Two years later, when Pound addressed the first meeting of the National Conference on Criminal Law and Criminology (June 7, 1909), he stated: "[The criminologist] complains that whereas it is demonstrated that in many cases what we call crime is a disease, the law persistently deals with every offender, unless he is of unsound mind, as a normal person, and as a reasoning being who has wilfully gone wrong." Procendngs supra note 88, at 1 (emphasis added). Note that Pound signed on to - perhaps coauthored - the general introduction to the Modern Criminal Science Series (1911), which explicitly stated: "It need not be asserted for one moment that crime is a disease." General Introduction, supra note 105, at vii. See supra text accompanying note 110 . 
he remonstrated. 167 Pound noted instances of inconsistent jury verdicts, which resulted from the variable influences of "sentimentality" or from varying reactions to the "unwritten law," which flourishes in one place as it withers in another. ${ }^{168}$ In closing, Pound prescribed "limiting the jury to their proper function of finding facts, and giving the court power to hold them to it," by which he seems to have meant giving judges the power of "fair comment on the evidence" and of alerting jurors to the "sophistry and buncombe addressed to them by counsel."169 Pound seems to have believed that immediate procedural corrections would eliminate, or at least limit, the tendencies of juries to respond variably and outside the strict rule of law to the vagaries of retributive or merciful impulses. Yet Pound also evidenced sympathy regarding some forms of jury "lawlessness" that responded to the gulf between individualistic legal conceptions and the social conception of justice. In that context the jury was not always retrograde, but sometimes, rather, progressive: "In a crude way, juries are continually attempting to apply a newer standard of justice, but half-grasped, and the result is shown in many otherwise inexplicable verdicts."170

Thus, true jury reform awaited the advent of sociological jurisprudence. That new day would bring forth a rational and consistent form of criminal justice, wherein retribution and the intent requirement would have given way to - what? A criminal jurisprudence that did not depend upon a concept of human free will? If so, was Pound prepared for the implications of so fundamental a transformation of law, of culture, of human psychology? Unlike Speranza, Pound had not yet gone to the heart of the matter. He had avoided the Scylla of despair and the Charybdis of utter "science." But, then, he was only getting underway. So far as one can tell, he had not yet truly confronted the challenge to will theory that science posed for law in the fin de siècle.

A seemingly unavoidable occasion for such a confrontation presented itself when, in 1909, Pound reviewed Maurice Parmelee's The Principles of Anthropology and Sociology in their Relation to Criminal Procedure. ${ }^{171}$ A social scientist with strong interests in

167. Pound, supra note 154, at 236.

168. Id.

169. Id. at 239.

170. Id. at 231.

171. Roscoe Pöund, Book Review, 3 Am. PoL. Scr. Rev. 281 (1909) (reviewing Maurice Parmelee, The Princtples of ANTHropology and Sociology in Their Relation to Crmminal Procedure (1908)). 
criminal anthropology - and a year or so later, a co-signer with Pound of the General Introduction - Parmelee supported the positivist school of criminal jurisprudence and argued in favor of a limited form of the social defense theory of criminal justice. Parmelee's critique of the classical school's reliance on the concept of free will was trenchant:

We have already indicated that [the positive school] does not accept moral liberty as a basis for penal responsibility. This does not mean that the existence of a free will is necessarily denied. As a matter of fact some representatives of this school deny it and others do not. But they all agree that even if it exists it is something so incalculable in its character that it cannot be considered in developing a science of criminology and in the practical treatment of crime. ${ }^{172}$

The "practical treatment of crime" depended upon the individualization of punishment; this in turn required a judiciary trained to gather data of an anthropological and sociological nature. ${ }^{173}$ Parmelee paid only intermittent attention to the dangers of the social defense. At times he wrote quite broadly: "[B]y carefully studying the criminal himself, his rights as an individual are abridged only to the extent that social welfare demands."174 Elsewhere he was more guarded, although perhaps less so than he himself recognized: "A positive [criminal] procedure must retain every guarantee of individual liberty ... . for the criminal so that restrictions placed upon him shall not exceed those demanded by social defense."175

Not surprisingly, Parmelee was hostile to the institution of jury trial. He conceded, in much vaguer terms than Speranza employed three years later, that juries kept "judge and justice in touch with the public"176 and that they tended to "individualize punishment," but he stressed that this form of individualization "has not always been on a rational basis." 177 Rather, he claimed: "In France, the tendency is to appeal to the passions, in England the tendency is toward excessive casuistry, but everywhere an oratorical character is given to the debate and a great deal of sentimental claptrap is introduced on account of the predominance of sentiment over rea-

172. Maurice Parmelee, The Principles of ANthropology and Sociology in Their Relation to Criminal Procedure 20-21 (1908) (emphasis added).

173. Id. at $400-01$.

174. Id. at 122 .

175. Id. at $130-31$.

176. Id. at 381.

177. Id. at 363-64. For Speranza's comments on jury behavior, see supra text accompanying notes 73-81. 
son in the jury."178 Parmelee looked forward, ultimately, to the abolition of jury trial in criminal cases. 179

Pound's response to Parmelee melded respect for the fin de siècle advances in criminology with a warning that the law must, in the short term, stand its ground. He proceeded upon the understanding that the scientist "refuses to define crime,"180 noting that "[b]y criminal procedure," Parmelee meant a "process by means of which the class called criminal is separated from the rest of society." "181 "[T]he law," Pound asserted,

must proceed from defined crimes and a from definite, settled theory. Hence, for the lawyer, the analytical view of crime, that it consists in doing what the State has forbidden under sanction of public prosecution, in violating a public duty, imposed, for whatever reason, by the State, is the only tenable one. ${ }^{182}$

Pound termed the practice of "deal[ing] with the criminal rather than with crime" the "criminologist's strongest point," but he insisted that "to minimize the dangerous possibilities of magisterial caprice, corruption or ignorance," the law required "generality, uniformity, and to a considerable degree mechanical action" - an inhospitable environment for individualization. ${ }^{183}$ The defense of political liberty required a cautious approach to implementing behaviorist doctrines and procedures. The power to legislate crimes and punishments carried with it the possibility of "dangerous forms of oppression of one class or one portion of the community by another"; whereas "one form of criminal procedure for all causes involving grave penalties will remain an indispensable protection to the individual."184 Pound recognized the tensions that his prescription entailed, and seems to have recognized also that, in practice, some form of mediation would — and should — result. In this respect,

[w]ithout some such dispensing power, the inherent mechanical tendencies in legal systems lead to worse results than the relaxing of logical principle and sometimes erratic short-cuts to crude equity characteristic of juries. Undoubtedly our law has carried protection of the individual much too far. Undoubtedly American criminal procedure has developed a sort of jury lawlessness. But the history that led up to the constitutional and common-law guaranties of individual

178. Id. at 366.

179. Id. at 384.

180. Pound, supra note 171, at 282.

181. Id. at 281 (quoting PARMELeE, supra note 172, at 7).

182. Id. at 282.

183. Id.

184. Id. 
rights and to the power of juries to render general verdicts may repeat itself, and is by no means to be ignored.185

Thus did Pound continue the dualistic approach to the jury as both necessary leavener and dangerous obstruction to justice that had characterized his earliest writing. ${ }^{186}$ Perhaps acknowledging the reach of behavioral science, Pound suggested: "In a crude way, juries are continually attempting to apply a newer standard of justice, but half-grasped, and the result is shown in many otherwise inexplicable verdicts."187 Pound seems to have anticipated Speranza's insight that juries were influenced by the rhetoric of penological reform, but whereas Speranza doubted the jury's ability wisely to apply the new science before its basic principles were embedded in official legal practice, Pound - in the interests of political liberty - now accepted ad hoc, jury-based applications of such ideas as, for the time being, the better part of wisdom. ${ }^{188}$

In his review Pound did pay lip service to the importance of behaviorist research on the Continent. But while recognizing its influence on many American reforms - he mentioned juvenile courts, the indeterminate sentence, and suspension of sentence ${ }^{189}$ - Pound remained skeptical of its ability to travel:

[O]ur criminal law is so rooted in theological ideas of free will and moral responsibility and juridical ideas of retribution, and both criminal law and procedure are so thoroughly mechanical, that we by no means make what we should of our discoveries.

The truth is ... criminal law is the most archaic part of our legal system. But it has to deal with some of the most modern of problems. It needs and will soon receive a very different form of study and a radically different type of treatment from those which have obtained in the past. 190

What did Pound mean by "theological ideas of free will and moral responsibility"? Identifying these as "Puritan" notions left

185. Id. at 282-83.

186. For another example of Pound's view on this aspect of jury behavior, see Pound, supra note 151, at 403 ("Juries are conscious that the law in some way does not accord with the general sense of right, and find verdicts which are crude attempts to vindicate halfgrasped conceptions of social justice.").

187. Pound, supra note 155 , at 231.

188. See supra text accompanying notes 70-81.

189. Pound, supra note 171, at 283. It should be noted that Pound looked upon the developments in juvenile justice with some ambivalence - or such was the case, at least, in 1912, when he considered the powers of discretion accorded to judges in those courts quite dangerous. Roscoe Pound, The Administration of Justice in the Modern City, 26 HARv. L. Rev. 302 , 322 (1913). Pound was not opposed to the institution of the juvenile court as such, but was concerned that judges be trained adequately to deal with the special problems of juvenile justice.

190. Id. at 283-84. 
open the possibility that Pound referred to absolutist notions imbued with ideas of divine inspiration, distinct from secular concepts of human freedom and morality that were commonly thought compatible with conventional notions of causality. Nonetheless, his writings on criminal justice from the following years, which often continued the religious characterization of free will, can indeed be read as calling for a concept of criminality that would exclude the element of free will almost entirely. ${ }^{191}$

Pointing in the same direction was Pound's statement that "for the lawyer, the analytical view of crime, that it consists in doing what the State has forbidden under sanction of public prosecution, in violating a public duty, imposed, for whatever reason, by the State, is the only tenable one."192 Pound contrasted this view with the criminologist's "refus[al] to define crime";193 due process and other essentially political considerations required clear and prefixed definitions of criminal offenses. Applied literally, this would allow for rejection of the application of any concept of free will to offenders and make possible legislative abandonment of simple intent in cases in which the state so desired; it would allow, too, for proceeding upon only those "mental" requirements prescribed in legislation, such as premeditation or malice. Nothing indicates that Pound ever repudiated these requirements in principle, though he would allow the State to dispense with them in some undescribed range of offenses.

Pound thus apparently conjoined a relatively statist approach to the common lawyer's perspective on the procedural aspects of political liberty with acceptance of some version of the scientist's perspective on human freedom. He appears to have gone beyond the Speranza of 1901, denying the need to accommodate the concept of free will and asserting that law could come to assimilate

191. See, e.g., Roscoe Pound, Puritanism and the Common Law, 1910 Proc. B. Assn. ST. OF KAN. 45:

So too, the retributive theory is almost among the fundamenta of our criminal law. We

look upon the criminal in the abstract. He is a free moral agent, who, having a choice

between right and wrong, voluntarily chose the wrong and must abide the penal conse-

quences appointed in advance. Not only does this Puritanical view of the matter keep

alive the retributive theory in jurisprudence, after kindred sciences have abandoned it,

but it hampers the efficiency of penal legislation intended to protect society.

Id. at 54; see also General Introduction, supra note 105 (bearing a close relation to the above statement and signed by Pound). The extent of the denial of the relevance of free will to the concept of criminality remains unclear, though Pound appears to be coming close to pushing it aside entirely. For Pound's repeated assertions to the same effect in the late teens and early twenties, see infra section II.D.

192. Pound, supra note 171, at 282.

193. Id. 
science in this regard and yet remain the law. But this is only as it seems. Pound never truly defined his terms. He always led from the perspective of the lawyer, and he always embedded his reformism regarding criminal justice within his more general thinking about the social order. At points Pound sounded themes that can be found in late-nineteenth-century juristic deterrence-based socialdefense writings - Hershey's voice can sometimes be heard. ${ }^{194}$ Rather than embrace that perspective fully, though, he seems to have drawn upon it in part and to have eschewed the whole. His true target was legal orthodoxy; his true goal - as suggested by his remarks on the jury's supplying "crude equity," where that was required - was a via media between that orthodoxy and its radical rival, as well as between the state and the individual, a balance that he apparently believed inconsistent with any version of a pure social defense position, just as he surely believed it was inconsistent with the criminologist's "refusal to define crime."

It is important to note that Pound's frontal critique of the "free will doctrine" emerged in the context of the criminal law. It has, to be sure, an important history in his work, in the form of his privatelaw critique of nineteenth-century individualism and in his stress therein on a sociological perspective. Little in his writing in this area, however, hints at the more holistic attack on the concept of autonomy that seems to have appeared at least by 1909 in his writing on criminal jurisprudence. In Liberty of Contract, ${ }^{195}$ Pound referred to "practical conditions of inequality,"196 and complained that justice had, in the nineteenth century, come "to be regarded as a device to secure a maximum of individual self-assertion"; 197 "Puritan theology," he claimed, "gave rise to ultra individualism ...."198 Here he seems to stress relative degrees of autonomy, whereas with respect to criminal justice he noted that Puritanism gave rise to "the doctrine that man was a free moral agent with power to choose what he would do and a responsibility coincident with that power," thus challenging the idea of autonomy in a more fundamental way. ${ }^{199}$ Pound's concrete examples, outside of the

194. See supra text accompanying notes 16-24. Hershey and Pound were in fact close friends during their Harvard student days (1889-90) and for many decades thereafter. See WIODOR, supra note 88, at 33.

195. Pound, supra note 122.

196. Id. at 454.

197. Id. at 459.

198. Id.

199. Roscoe Pound, The Ritual of Punitive Justice, in 1909 Proc. Wisc. CoNF, ON Crms. L. \& Crommolooy 36, 42. Yet Pound opened the 1909 Chicago Conference with a brief 
criminal law, are instructive. Pound criticized one court for failing to "consider that laborers in mines may be in a continual condition of poverty, and, that, as Lord Northington put it: 'Necessitous men are not, truly speaking, free men, but, to answer a present exigency, will submit to any terms that the crafty may impose upon them. " 200 He noted, "It is said that statistics show the great majority of accidents happen in the last working hour of the day, when the mind is numbed and the operative has ceased to be the free agent which our law contemplates." 201 As to the remedy for such situational unfreedom: in The Need of a Sociological Jurisprudence, Pound noted the advances signaled by legislation that took account of the actual position of individuals in society, a trend he identified with a newly emerging "moral sense of the community," and "the custom of the people, the expression of their habits of thought and action as to the relations of men with each other." ${ }^{202}$ Surely these popular "habits of thought" did not embrace a rejection of the notion of free will! He contrasted these tendencies to "the general moral sense of the past," "the older individualism," and "individu-

statement that included the observation: "Then, again, we have, especially in the criminal law, and in many places in the law of torts, ideas of free moral agency and responsibility carried to an extreme." See ProceEdings, supra note 88 , at 2 . Here, Pound equated criminal and some noncriminal doctrines; Pound's perspective appears to be relativistic as to both. See also Roscoe Pound, Law in Books and Law in Action, 44 AM. L. Rev. 12, 32-33 (1910) [hereinafter Pound, Law in Books]; Pound, supra note 191, at 50-52. Note, however, the passage in which Pound wrote:

[O]ver-individualism ... expresses the feeling of the self-reliant man that, as a free moral agent, he is to make his own bargains and determine upon his own acts and control his own property, accepting the responsibility that goes with such power, subjecting himself to liability for the consequences of his free choice, but exempt from interference in making his choice.

Pound, Law in Books, supra, at 26. Here, "over-individualism" (with respect to contract and property) is associated with the belief that one, "as a free moral agent," may behave a certain way. Pound did not clearly state that the belief that one is a "free moral agent" is itself false. By contrast, he seems to argue that "free will" is a false belief in the context of the criminal law. Between 1913 and 1919 Pound came to characterize "free will" generically as a mere feeling, a clear extension of the ideas he was expressing here. Even then, however, it is not clear that he ceased to treat contract relations in terms of relative degrees of freedom. See infra text accompanying notes 235-43. It is possible that, as of 1910, the "free moral agent" concept that Pound opposed, both in criminal and in private law, was the absolutist version of the idea, and that he had not fully rejected the concept of free will. Rather, he absorbed a version of the behaviorist critique of the doctrine, assumed that human freedom was greatly limited by circumstances, but assumed also that under the right conditions - conditions of rough equality - humans could exercise "liberty," which he seems to have equated with freedom. Pound may have thought that the very fact that a person had committed a "crime" demonstrated he had not - under the prevailing circumstances - possessed a free will or "liberty." Thus, his critique of the concept of free will in the context of the criminal law was both more emphatic and stated in a fashion that implied its total rejection.

200. Pound, supra note 122, at $471-72$ (criticizing and quoting Vernon v. Bethel, 2 Eden 110, 113, 28 Eng. Rep. 838, 839 (1762)).

201. Pound, supra note 191, at 53 (emphasis added).

202. Pound, supra note 124 , at 612,615 . 
alist theories," which still governed the training of bench and bar and, hence, the responses of courts to the new legislation. ${ }^{203}$ Pound also contrasted the traditional common law view to the new sociology, "the direction of popular thought," and "the unconscious drift of the law," by which he meant not only legislation but also jury verdicts in some kinds of private law cases involving egregious imbalances in bargaining power. ${ }^{204}$

Pound confronted the free-will doctrine head on in the domain of criminal jurisprudence, having been drawn out into the open by the behaviorist perspective represented in Parmelee's 1908 book. Here, a divide opened in Pound's thinking, one that, as we have seen, was endemic to the early twentieth century generally. Pound reflected the tensions between an anti-free-will view and the attractions of a more relativistic position. He had by 1909 grasped the nettle, but the resulting tensions played out more profoundly in the context of his criminal law writings.

In truth, even within his criminal jurisprudence, Pound's constant reiteration of the need to reform the orthodox theory of criminality was in powerful tension with his desire to maintain protection of the individual - the vindication of political liberty. ${ }^{205} \mathrm{He}$ seems not to have fully understood this, and he never stopped saying that eventually society would solve the problem of absorption of the new sciences without surrendering basic liberties. As we shall see, affirmation of the concept of human freedom crept into his later work, when he moved back from the criminal law per se to focus upon the workings and purposes of the social order generally. But

203. Id. at $612,613,615$.

204. Id. at 612 .

205. See, however, Pound's remarks at the 1909 National Conference on Criminal Law and Criminology, when he was drawn into a heated discussion of the possibility of scientific determination of the "criminal type." ProceEDINGS, supra note 88 , at 89-98. Pound began quite tentatively:

I don't think that any criminologist now claims that probably we shall ever be able to look at a man and say that he is necessarily a criminal. On the other hand they do believe, and they seem to have a good deal of warrant for believing, that there is to a certain extent - just how great that extent is we cannot tell - a physical type of person who is born with anti-social tendencies, which we call criminals; that is, his physical make-up is such that he has the tendency to do those things which are anti-social.

Id. at 92-93. He noted that such study was proceeding in Europe, where "they have a freedom of dealing with criminals ... which we do not have in this country. In this country, in accordance with the requirements of due process of law, very little can be done beyond what any person may voluntarily submit to." Id. at 93 . Pound warmed to his subject:

If we are to accomplish anything in this country we have got to have general laws providing for some such mode of investigation. I do not know how far at present it is practicable, but that in the future something of the sort will have to be done, I really have not much doubt. ... It runs somewhat counter to our Anglo-Saxon notions, but it will come. As to how far it is an immediately practical question, I confess my mind is still open. Id. Pound did not address the question of the use of the results of such (future) studies. 
this is to get ahead of the story, for the tensions in Pound's work are most profound, and most telling, during the late teens and early 1920s. First, we must complete our assessment of the early, prewar Pound with some observations on his growing frustration with the criminal trial jury.

The jury fared reasonably well in Pound's review of Parmelee; it reflected the moral sense of the community in adjusting the mechanical legal rules that could not be altered suddenly in a society devoted to political liberty. And its virtues, as Pound portrayed them, exposed the dangers of a trial in which the jury was restricted to a mere determination of whether the defendant had committed an "act" that the state had defined as a crime. But that was Pound playing defense against the overreach of the new science. Between 1909 and 1911, Pound came to view the criminal trial jury with increasing skepticism. In his introduction to the 1911 English translation of Raymond Saleilles' classic work, The Individualization of Punishment, Pound was downright negative.206 Pound had signed and quite possibly written the potentially far-reaching General Introduction to the Modern Criminal Science Series; ${ }^{207}$ and in his own introduction to Saleilles he seems temporarily to have abandoned one of his most cherished positions, that law must reflect evolving social attitudes. He now associated Amos with those who deemed mechanical, as opposed to individualized, justice as "fundamental."208 Amos, he said, stated the conventional theory "as a matter of course, with no hint that we may attain anything better."209 Pound rehearsed once again the reasons for an overly mechanical criminal law — by then tired-sounding phrases - and noted that the "equities" of individual cases had been left to juries. Far from serving as a needed countermeasure, however, jury intervention had made it difficult for courts "to procure convictions at all in cases of homicide."210 As a result, many jurisdictions had left the penalty to the jury only to find that this produced wild inconsistencies. Pound now concluded:

Obviously the crude individualization achieved by our juries, and especially by leaving the assessment of penalties to trial juries, involves quite as much inequality and injustice as the mechanical application of the law by a magistrate. Unchecked jury discretion upon the whole

206. Roscoe Pound, Introduction, in SALEILLES, supra note 105.

207. See supra note 105 and text accompanying notes 99-108.

208. Pound, supra note 206 , at xiv.

209. Id. at Xv.

210. Id. at $\mathrm{xV}-\mathrm{xvi}$. 
is worse than the unchecked magisterial discretion from which the classical school sought to deliver us. ${ }^{211}$

Although Saleilles himself addressed the problem of responsibility as well as that of punishment - and, indeed, offered a middle position, albeit opaque, that saved something akin to conventional theory, ${ }^{212}$ Pound seems to have been paying increasing attention to the sentencing stage, when a better educated judge should apply the new learning and - perhaps Pound did not consciously think of it in this way - make up for the inevitable infirmities of the guiltassessment stage. Clearly Pound's patience with the criminal trial jury had worn thin. He had already begun to accept the view, much in the air at the fin de siècle and constantly reiterated in AICLC speeches and writings circa 1910, that the English version of the criminal trial was far superior to the American. In part, Pound thought this was the result of English juridical theory: "In England, where an unfettered Parliament makes the written law sensitive to public opinion, there is very little jury lawlessness."213 But Pound did not always permit this perspective to temper his impatience with the American criminal jury, which existed in what he well understood to be a very different socio-legal climate. The English trial became an example for reform in the here and now.

When, in 1910, Pound had reflected sympathetically on jury intervention - in the second-best here and now - he had singled out, inter alia, the tendency of the jury to correct for the mechanical nature of the law of insanity.

Jury lawlessness is the great corrective of law in its actual administration. ... [W] $[\mathrm{Were}$ in a particular cause there are peculiar considerations of mitigation or circumstances requiring exercise of a dispensing power, the power of juries to render general verdicts needs only a little help from alienist theories of insanity to enable a verdict to be rendered which will accord with the moral sense of the community. Here again, as in the case of the "third degree," the law is often too mechanical at a point requiring great nicety of adjustment. ${ }^{214}$

A year later, in the wake of the Strasburg decision, which Pound saw as just another unfortunate victory of "classical theory" over

211. Id. at xvii (emphasis added). Note, however, that Pound was friendlier in his Introduction to the civil trial jury. Id. at $\mathrm{xv}$.

212. SALEILIES, supra note 105, at ch. 6. For an excellent discussion of Saleilles's views, see GARLAND, supra note 14, at 186-89. Garland addresses Saleilles's concept of the "subjective reality" of free will, SALEILIES, supra note 105, at 158-59. As I shall argue, Pound came to a similar position a few years later; possibly, he was influenced by Saleilles in this regard, but neither his Introduction nor his later writings specifically suggests that he was. For further discussion of Pound's views regarding the consciousness of freedom, see infra note 242.

213. Pound, Law in Books, supra note 199, at 19.

214. Id. at 18. 
"modern legislation,"215 Pound's tolerance had largely evaporated. "Exercised in homicide cases," Pound wrote, the power of juries to render general verdicts "led to the situation Mark Twain satirized when he called upon the legislature to make insanity a crime."216

Pound was commencing an important transition. Specific examples of progressive criminal trial jury responses - reflecting emerging social customs and embodying "newer standards" that were "half-grasped" - would, within a decade, become little more than a part of frontier justice, reflecting "pioneer ideas," or responses to the "unwritten law."217 By then, however, the experience of the Progressive Era had reoriented Pound's perspective. New tensions had set in. On the one side, Pound responded to the seduction of massive, government-sponsored social reform. These projects were still only partly effected but nonetheless sufficiently advanced that mediating institutions like the jury were unnecessary intrusions rather than necessary evils. On the other side, Pound recognized the incipient dangers of too much reform, especially the threat of a criminal law dominated by the collective - and administrative state. Basic protections would remain necessary; the new theory would have to be assimilated carefully and - as always - gradually. Individual liberty, once too great, would now have to be protected against the needs of organized society. The cycle was changing. Human freedom would now have to be redefined as itself a social interest and as valid as such. And, as such, jurisprudence would have to insist upon it. But Pound did not refer to the orthodox theory of free will in the criminal law, nor did Pound refer to the "corrective" powers of the criminal trial jury. For a new age, Pound postulated a new version of an unstable mix of ideas.

\section{C.}

Pound's 1916 speech, Juristic Problems of National Progress, 218 represents the first stage of Pound's mature work on criminal jurisprudence. The years of work on his tripartite study of sociological jurisprudence 219 and on many briefer succeeding essays had served him well. So, too, had the prewar era of high Progressivism influ-

215. Pound, supra note 206, at xi. See supra notes $99-100$ and accompanying text.

216. Id. at xvi (referring to MARK TwaIN, $A$ New Crime, in SkETCHES NEW AND OID 220 (1875)).

217. See infra text accompanying notes 299-309.

218. Roscoe Pound, Juristic Problems of National Progress, 22 AM. J. Soc. 721 (1917).

219. Roscoe Pound, The Scope and Purpose of Sociological Jurisprudence (pts. 1-3), 24 HaRv. L. Rev. 591 (1911), 25 HaRv. L. Rev. 140 (1911), 25 HaRv. L. ReV. 489 (1912). 
enced Pound's thought - deepening it and producing an attractive selfconsciousness. Pound continued to believe that the role of law - of society in general - was the "satisfaction of a maximum of wants with a minimum of sacrifice of other wants" rather than, simply, the maximizing of individual self-assertion. ${ }^{220} \mathrm{He}$ had grown increasingly convinced, though, that the moral and social life of the individual and, indeed, the preservation of what he now called free individual action were among the most basic wants and, hence, were themselves central social interests. ${ }^{221}$ This turn of thought Pound's application of social-interest theory - accompanied his fear that the drift toward centralization, the eclipse of the judicial process by newly-minted administrative agencies, and the sheer mass of legislative mandates would undermine political liberty, overall social efficiency, and, especially, individual freedom. This new emphasis on "spontaneous individual action" significantly heightened the tension that plagued his criminal jurisprudence. But operationally, what did this language of "freedom" mean? How did it come to play so important a role for Pound in the life of the law? We must answer these questions in order to assess Pound's evolving criminal jurisprudence. We should begin by noting the role this new language played in Pound's 1916 speech.

Pound began the speech by criticizing the old theories of law making as "necessitarian." 222 "[In] [t]he seventeenth and eighteenth centuries," he wrote, "men conceived they were finding law while making it. To these centuries all law was inevitably deter-

220. Pound, supra note 218 , at 724 .

221. On the derivation of Pound's theory of social interests, see Wrodor, supra note 88, at 210-14. Wigdor emphasizes Pound's attraction to "organicism" and to the idea of "relation." "It was more meaningful to interpret rights, duties, and liabilities as incidents of a relation rather than as terms of a transaction or a culpable action. Thus the rights and responsibilities of employer and employee received their legal definition in terms of the relationship of the parties rather than the will of the parties." Id. at 211. Wigdor traces the idea of organicism to late-nineteenth-century thought, see especially id. at $325-26,326 \mathrm{n} .11$, and concludes that, with respect to his social-interest theory, Pound was influenced first by Jhering, but more importantly ("directly") by Albion Small. Wigdor states that "Pound hoped that this theory would replace the conventional preoccupation with 'rights' as the basis of law." Id. at 213.

HERGET, supra note 119, at 167-69, establishes the relationship between Pound's theory of social interests and the ideas Pound gleaned from Jhering, Kohler, and William James. Herget states that, for Pound: "To have a chance of being accepted, these claims [i.e. "interests"] must be more than mere personal demands; they are asserted to be morally right, accepted by society, and generally applicable to some particular class or group of persons." Id. at 168.

Pound's attention to social interests became a dominant theme in his criminal-justice writings at least as early as 1912. See Pound, supra note 189. For further discussion of the background for Pound's social interest theory - and the claim that Pound gave these ideas a distinctive tum - see SAYRE, supra note 119, at 359-64.

222. Pound, supra note 218, at 723. 
mined by the nature of man ...."223 The nineteenth century jurist "came to doubt whether he could do more than observe the processes by which legal rules and doctrines took their predestined shapes."224

The irresistible movement of the ethical or political ideal to realize itself, the inevitable operation of natural forces as completely beyond human reach ... the relentless working out of biological laws as hard and unyielding as those that shape animal and vegetable life - these ... convinced men that the most that legal science could do for us was to teach us to observe nature's machine in operation .... . So obstinate are these modes of thought that the economic interpretation which has been passing for modern and advanced in much recent juristic writing is essentially of the same necessitarian character. 225

"The time," Pound announced, "calls for voluntaristic theories of lawmaking on the part of jurists and judges," or what he called an "engineering interpretation of jurisprudence."226 The watchword of such an interpretation would no longer be efficiency, but, in the military fashion of the day, "organization and preparedness"; the new legal science would be one that "constructs as well as observes . . . that observes in order that it may construct."227

Pound anticipated objections to such a "voluntaristic philosophy of lawmaking," the most serious coming from the "political and philosophical individualist," who will "say that the grain of truth in the nineteenth-century theories of juristic and legislative futility is in the necessity of safeguarding this spontaneity of individual action, this individual initiative in thinking and acting which is the mainspring of progress."228 But Pound rejected this argument as failing to take account of the "ever-widening recognition and securing of social interests." 229 The essentially eighteenth-century perspective on justice "as a problem of reconciling government and liberty," had given way, Pound claimed, to "a problem of reconciling organization with spontaneous individual effort; of reconciling social control with individual initiative."230 The formulation was not entirely new for Pound, but it was more elaborate and uttered with greater urgency. Something very like the language of

223. Id.

224. Id.

225. Id. at 723-24.

226. Id. at 724 .

227. Id. at 724-25.

228. Id. at 725-26.

229. Id. at 726 .

230. Id. at 727 . 
human free will was becoming a staple of Pound's social theory and jurisprudence.

To illustrate the objectives of an "engineering interpretation of jurisprudence," Pound chose the criminal law, labeling it "a wellunderstood body of tradition proceeding on one theory on which we have grafted an overgrown mass of legislation proceeding on many diverse and conflicting theories," and claiming that "it is no one's business to put the whole into even the semblance of order, much less to survey the whole, trace its different constituents with reference to the ends to be attained, and seek to make it more effective toward those ends."231 Pound had initially encouraged the proliferation of interdisciplinary writings under the auspices of the AICLC as a route to greater comprehension. ${ }^{232}$ Now, seven years later, he vainly but optimistically struggled against the centrifugal energies that had - one might have thought, predictably - been released, depicting criminal law as fragmented into a "medical view in which the criminal law is thought of in terms of the insane and the epileptic"; a "psychological view in which it is thought of in terms of the feeble-minded"; as well as the perspectives of penologists, social workers, and the police. ${ }^{233}$

This focus on system and overall coordination - in the "military" style or otherwise - dominated Pound's later writings generally. It simultaneously reflected Pound's deep skepticism that mind, man, or society could be understood from any one particular perspective - and his naive faith in a holistic approach to solving problems, one that melded the best of all available ideas. Pound's skepticism had also a larger dimension, that of the historicist. No age found final answers but only solutions suitable to itself. This aspect of his skepticism - a species of relativism - left room for belief in the existence, at any one time, of general social mores, of ideas, attitudes, and practices that bound a society together and that provided the basis for consensus despite the presence of competing interests. This blend of elements that underlay Pound's engineering interpretation of jurisprudence eventually separated him from the postwar realists, whose private-law writings typically denied the existence of pervasive, society-wide moral conventions and stressed the arbitrary quality of judicial decisionmaking..234 Nowhere did

231. Id. at 728.

232. Proceedings, supra note 88 , at 3.

233. Pound, supra note 218 , at 728-29.

234. See, e.g., White, supra note 119, at 1010-21. 
Pound make his case more emphatically, however, than with respect to the criminal law.

Pound soon integrated his insistence upon the need for system and coordination with his new-found attention to "individual freedom and individual initiative." In 1919, in one of his least known, yet most revealing essays, Society and the Individual,23s he stated that individual interests lay side by side with "public interests," which are "the claims which the state may make simply as such," and "social interests," which included, inter alia, "the social interest in the individual human existence."236 Individual interests, then, received both separate treatment and a place within social interests. It is fair to say that Pound was attempting to redress a movement in the direction of the collective state to which, he may well have feared, his own early writings had contributed. His argument, stated in generalities that failed to make clear the nature of the "freedom" he was now attributing to the individual, extended ideas that he had expressed at least as early as 1910 and that seem to have crystallized steadily in the 1913-1919 period.

In this piece, Pound briskly denounced the classical view of "society and all social groups as products of individual agreement," and produced the most comprehensive deterministic account of human thought and behavior that, to my knowledge, he ever set forth:

Metaphysically the individual conscious ego may, if you will, be the unit. But it is a profound mistake to take that ego for the ultimate reality in the social world. You and I are born into the great stream of society. We die out of it. But it went on before us and will go on after us, and if some of us are able to do something to shape some part of its course, yet how much more will it have shaped us, molding our thoughts by fixing the conditions under which and words by which we think, controlling our actions by bonds of convention, fashion, general opinion, of which we are hardly conscious, which we can resist only here and there, and then often but feebly, and forming our very personality by the pressure day and night of a thousand points of contact with our fellows in the stream. So true is it that the individual is a social product or a social outcome rather than society an individual product. 237

Pound did not say how long he had held this general view, which had long been fashionable in social-science - but not, so far as one

235. Roscoe Pound, Society and the Individual, 1920 Proc. NATL. CONF, ON SOc. Work 103 (Conference held June, 1919).

236. Id. at 103, 104-06 (1920).

237. Id. at 104. 
can tell, in legal-academic - circles.238 Nor can we know how much leeway the power to "resist only here and there, and then often but feebly" allows. Pound rushed on, commenting that

[a] few years ago all this was, one might say, trite. But a reaction has set in. Men have come to fear that in this emphasis on the social stream the interests of the individual in the stream will be overlooked and neglected - as it has been said, that our social thinking would abolish the individual. Thus there is coming to be a marked revival of the abstract individualism against which we were all in revolt a decade ago. 239

But for Pound, the art of social engineering was the art of compromise:

I submit the way to meet this reaction is to recognize the kernel of truth in the old individualism - that is, that one of the chiefest of social interests is that each individual have an opportunity to lead a human life; to recognize a social interest in the moral and social life of the individual, and to recognize that one of the chief agencies of social progress is individual freedom and individual initiative. ${ }^{240}$

Here Pound moved from his tentative, distancing phrasing of two years earlier - "the political and philosophical individualist ... will say that [there is a] grain of truth in the nineteenth-century theories" 241 - to his own forthright recognition of "the kernel of truth in the old individualism." This "truth" would be conceded and the individual interests would be reconceived as at once self-standing and an aspect of the social interest.

Pound seems to have defined the freedom to which he had referred increasingly in recent years as the consciousness of freedom, rather than as an "ultimate reality," and its recognition as a social interest - or possibly the belief in its being an ultimate reality as a social interest. This pragmatic approach to human freedom kept

238. Pound read voraciously (see HeRGET, supra note 119, at 164-65), but he often reduced many variations on a theme to an effective (and affecting) monovocal synthesis. Pound had been influenced by James, Dewey, and a great many others with respect to both pragmatism as a general matter and an interest in consciousness and experience more specifcally. (For an excellent study of will, consciousness, and "pragmatic truth" in late-nineteenth and early-twentieth-century thought, see KropPENBERG, supra note 126, at 64-94.) I have not attempted to associate specific Poundian formulations with specific social-science or philosophical writings. Pounds "methodology" makes it difficult to do so; his lack of philosophical depth (which is not to say lack of learning and wisdom) makes it a bit beside the point. I have sought to show how Pound applied his learning; others will shed more light than I can on the specific sources of that learning.

239. Id. It is not clear what Pound is referring to here; his comment might reflect ongoing trends in "domestic" political and social thought or it might reflect the reaction against either Marxist ideas or against certain strands of German thought that emphasized the community over the individual.

240. Pound, supra note 236, at 104 (emphasis added).

241. Pound, supra note 218 , at 726. 
social interest and social coordination - hence, "compromise" in the foreground. It allowed for restraints on human freedom on essentially utilitarian grounds, even as it recognized that freedom as a central feature of human existence, of what it meant to be human. Born of concerns regarding political liberty, Pound's belief in a species of human freedom remained an aspect of his largest concern: social engineering as a means of achieving the well-being of the social order generally. ${ }^{242}$ Through it all, Pound's concept of "individual freedom" remained supremely vague. His distinction between the perspectives of the "ultimate reality" and the "conscious ego" remained, I believe, the critical background idea, but Pound seems occasionally to have lost sight of it. He sometimes sounded as though "individual freedom" was a reality, sometimes as though it was a mere "claim," in the sense of belief. He, himself, might have thought of it as sometimes one, sometimes the other.

The slipperiness of Pound's idea of freedom is evident in his application, in 1921, of social engineering to private law:

242. It is possible that Pound was influenced by Parmelee, or that they mutually influenced one another. Parmelee had in 1916 defined "normal life" as "the spontaneous expression of human nature," and had concluded: "Now it is evident that in any organized society the spontaneity of the individual must be limited at least a little by the need for a certain amount of social control." Maurice Parmelee, Poverty and Social Progress 452 (1916). Pound had referred to "spontaneous individual effort" in his 1916 speech in a similar context: "We may restate [the matter] as a problem of reconciling organization with spontaneous individual effort; of reconciling social control with individual initiative." Pound, supra note 218, at 727; see supra text accompanying note 230. Two years later, Parmelee wrote: "But the progress of science has destroyed for all practical purposes the theological and metaphysical doctrine of a free will"; he warned that "fear," as an aspect of the penal function, while useful, "stands in the way of many changes which will prove to be beneficial, and thus impedes social progress. Furthermore, it prevents the highest possible degree of free activity on the part of human beings, and thus hinders the spontaneous expression of human nature which should be the principle object of civilization and of human culture in general." MAU. rice Parmelee, Criminology 379, 384 (1918). Pound and Parmelee appear to have tracked one another. Pound expressed his views regarding "spontaneous individual effort" within the context of his theory of the social interest. Parmelee led more from the perspective of achieving progress while not sacrificing social control. In one important particular, Parmelee seems not to have influenced Pound. In his 1918 book, Parmelee adopted a view that, he said, reconciled the problem of responsibility: "while it is true that the human organism and human nature have been determined by all the forces which have acted upon them, it is also true that this organism is a complex mechanism and center of energy from which radiates stimulations and impulsions which may have far-reaching consequences. Furthermore, as an organism it is highly self-directing, more so, indeed, than any other organism. Consequently, we have every reason to regard the human organism as an efficient cause of the deeds which emanate from it, and the consequences of those deeds. In this positive and scientific sense, then, we may regard the individual as responsible for his conduct." PARMELEe, CRIminology, supra, at 380. Parmelee drew here upon Ray Madding MoConneli, CRIMINAL ResponsibIITY AND Social ConstraInt (1912). See especially id. at chapter 12, entitled "Freedom as the Absence of External Constraint." Pound appears to have avoided this language and to have rested his views on the consciousness of freedom. Note, however, that Pound's protége, Sheldon Glueck, expressed views similar to those of Parmelee. See infra text accompanying note 354. 
An important phase of this interest in the individual life calls for security to free and spontaneous self-assertion .... . But there are many conditions in the life of today in which other phases of this interest must come into account... . Today our statute books have come to be full of ... restrictions. We do not ask: What will promote the maximum of abstract freedom of contract, taken as the end of law? We ask rather: Does it secure a maximum of interests with a minimum sacrifice of interests to leave such persons free to contract as they choose, or must the legal order, in a wise social engineering, hold down their free self-assertion for a time in certain situations? ${ }^{243}$

Here Pound stressed the point he had made from the very start: "Freedom" is subject to limitation by the legal order. Perhaps his social-interest theory was simply an aspect of his earlier sociological jurisprudence, but clearly he now asked different questions. He had found room for a significant measure of "free individual initiative" in property and contract, though, of course, he did not refer to it as the exercise of free will. Although the "freedom" he here described probably did not reflect "ultimate reality," in private-law matters the Progressive legal order could adjust for real imbalances in the practical ability of persons to exercise the freedom they imagined they possessed in some ultimate sense. There were tensions among the strands of thought in Pound's private-law writings, but on the whole in that context, his open references to compromise and coordination papered over those tensions. Social engineering was a "functional" approach precisely because it recognized competing interests, among them the claim to human freedom as an

243. Roscoe Pound, $A$ Theory of Social Interests, 15 PROC. OF THE AM. Soc. Socy. 16, 2728 (1921) [hereinafter Pound, $A$ Theory of Social Interests] (footnote omitted); see also Roscoe Pound, The Administrative Application of Legal Standards, 42 REP. AM. B. AssN. 445, 450 (1919) [hereinafter Pound, Administrative Application] ("[W]e are forced to admit that a wise engineering may hold down free self-assertion in many situations and is not bound, as a condition of rightful existence, to leave all men free to contract or to conduct enterprises with the minimum of restriction necessary to keep the peace.").

Note that in $A$ Theory of Social Interests, Pound quoted William James: "Must not the guiding principle for ethical philosophy ... be simply to satisfy at all times as many demands as we can?" " Pound, $A$ Theory of Social Interests, supra, at $28 \mathrm{n} .1$ (quoting WILLIAM JAMES, The Moral Philosopher and the Moral Life, in THE WILL To BeLIEVE, 205 (New York, Longmans Green \& Co. 1897)). Some thirty years later, Pound modified his views:

But thinking of the civil side of the legal order, I have come to feel that instead of putting the task of law, as William James did, in terms of satisfying as much as we can of the total of human demands, we do better to speak of providing as much as we may of the total of men's reasonable expectations in life in civilized society with the minimum of friction and waste. Free self-determination is a much prized and eminently reasonable expectation which must ever be weighed in adjustment of relations in and by politically organized society.

Roscoe Pound, The Role of the Will in Law, 68 HaRv. L. Rev. 1, 19 (1954) [hereinafter Pound, Will in Law] (footnote omitted). Pound restricted himself here to the private law: "I say nothing of the role of the will in criminal law." Id. 
aspect of human consciousness that engendered both social progress and the individual's sense of well-being.

With respect to criminal jurisprudence, the matter was very different. In that setting, to be sure, post-hoc adjustment via the application of rules of law, expert opinion rendered in the course of the judicial process and judicially administered penology could go a long way. But Pound was convinced that attributing true autonomy to criminal offenders was factually wrong, productive of retributivism, and detrimental to the social interest in dealing intelligently with the underlying causes of crime. Inevitably, Pound's references to free self-assertion - heuristic or otherwise - seemed to clash with his continuing critique of the role of free will in the orthodox theory of criminality. This contradiction was often lost, though, in Pound's focus upon the need for a rational, coordinated, functional system of criminal administration. When Pound wrote about criminal justice as the balancing of the social interest in public order and the social interest in the individual — in that context, he resorted to the ambiguous language of human freedom. But when he focused specifically on the underlying theory of criminal responsibility, he carried over his comprehensive-sounding rejection of the nineteenth-century concept of free will. All of Pound's major writings of the early 1920s on the criminal law and its administration manifest these ambiguous tendencies.

Pound's most important application of his theory of social interests to criminal justice appeared in The Future of the Criminal Law, a paper he gave at the American Prison Congress in the fall of 1920.244 In this setting, though, where one might expect sustained attention to the enduring problems that the new science presented for an underlying theory of criminal responsibility, Pound addressed instead the issues of political liberty and the place of criminal law - mainly those procedural aspects that reflected its highly charged political role - in the story of the West and, finally, in the story of modern America. It is here that Pound suggested most strongly that collectivism might, in some spheres, have gone too far. ${ }^{245} \mathrm{He}$ gave great scope to his longstanding concern about the use of administrative agencies rather than the common-law courts to resolve issues of criminal justice, referring inter alia to boards of probation and parole, whose role reduced the court's participation

244. Pound, supra note 133. The paper was originally published in 1920 Proc. ANN. Congress Am. Prison Assn. 68.

245. Pound, supra note 133 , at 9-16. 
in sentencing to a mere formality. ${ }^{246}$ In other contexts, judicial determinations were being preempted by preliminary reports by "alienists or psychiatrists" or by "boards and commissions" that resolved matters through "inspectors and secretaries and agents."247 Avoidance of regularly constituted judicial tribunals meant loss of protections against governmental overreach. But even in those courts, there was overreach: "American prosecutions today are coming to be conducted with a ferocity without parallel in commonlaw trials since the Stuarts." 248

Pound's essay presented in brief compass his pendulum-swing schema for criminal justice history: Periods of repression were succeeded by periods of relaxation of authority. The exaggeration of individual freedom in eighteenth- and nineteenth-century America, long the bete noir, had given way to a social perspective - Pound had himself campaigned for that change - but there were signs that, in some respects, the pendulum had now swung too far. As Pound saw it the institutions of Progressivism threatened the very values that Progressives had sought to restore and to protect. The post-World War I war on crime - including, one supposes, the Red Scare - severely compromised political liberty and the due process of law. Pound identified the emerging problem of overemphasis on the state as a failure on the part of jurists and others to perceive that the moral and social life of the individual was itself a central social interest. This problem was especially pressing in criminal justice, where the implications for political liberty lay on the surface.

Once again - and here perhaps more than anywhere - criminal law needed compromise: "Compromise of such claims, for the purpose of securing as much as we may, is peculiarly difficult. The

246. Id. at 1.

247. Id. A harbinger of Pound's criticism of the displacement of the regular judicial process by administrative process can be seen as early as 1912 in his cautious approach to juvenile courts, see supra note 189. Again, in 1914, Pound revealed some significant ambivalence in describing reforms in criminal justice:

Even in criminal causes, which we think of as par excellence the domain of the common

law, juvenile courts, probation commissions and other attempts to individualize the

treatment of offenders, and the endeavors of the medical profession to take questions of expert opinion out of the forum and commit them to a sort of medical referee, bid fair to introduce an administrative element into punitive justice which is wholly alien to our inherited ideas.

Roscoe Pound, Justice According to Law (pt. 2), 14 Colum. L. Rev. 1, 14 (1914) (footnote omitted). Pound's essay, Juristic Problems of National Progress, supra note 218, makes the point with evident force. Horwitz argues that Pound was friendly toward the administrative process until his "about-face" on the matter in the late 1930s. Horwrrz, supra note 116, at 217-20. This appears to be true with respect to noncriminal matters, but not as to the criminal law.

248. Pound, supra note 133 , at 9. 
far-reaching nature of the interests involved calls for the best of which the science of law is capable." 249 But what was "free individual initiative"? Was it merely a "claim"? Had Pound embraced the concept of free will? Had he altered his oft-repeated critique of the role of that concept in criminal law?

Pound's reiteration of his standard view bears close scrutiny. Pound complained - according to form - that "instead of intelligent compromise, our juristic theory of the past has sought to proceed on the basis of one of the two contending elements exclusively." 250 Thus, in the seventeenth and eighteenth centuries, American "theories of natural rights exalted the social interest in the individual life at the expense of the social interest in the general security."251 The criminal law infringed those rights; thus "it had to be justified by deriving its rules, its sanctions and its authority . . . from the free will of the offender himself."252 The problem was intensified in the nineteenth century, when "the fashion of juristic thinking sought to make the individual free will, as an ultimate metaphysical datum, the starting point of all legal obligation."253 From this experience it followed that "limitations on magisterial enforcement of the prohibitions imposed to maintain the general security ... should receive the whole emphasis."254 Later, Pound came back to this theme, noting that the same legal profession that needed to be warned about executive overreach "still adheres either to the eighteenth-century idea of natural rights as qualities of human beings ... or to the nineteenth century will-philosophy, with its ideas of free will, vicious will and abstract will, which modern psychology has wholly undermined."255

Pound then followed his standard critique with the phrase he had employed in his 1916 address on "Juristic Problems"256 and his 1919 remarks on "Society and the Individual,"257 though here he seems crucially to have aimed it directly at the "ideas of free will" in the criminal law: "I concede that there is a kernel of truth in these traditional legal theories."258 The concession seems especially

249. Id. at 11.

250. Id.

251. Id.

252. Id.

253. Id.

254. Id. at 12 .

255. Id. at 15.

256. Pound, supra note 218.

257. Pound, supra note 236.

258. Pound, supra note 133 , at 15 : 
far-reaching, but - then again - was it? Pound now directed his attention to wholly instrumental considerations: "We may not ignore the element of limitation upon magisterial enforcement of the prohibitions of criminal law and pin our faith wholly in administrative agencies that look upon criminal law purely from the standpoint of these prohibitions." 259

Had the perceived threat to political liberty engendered a belief in the kind of human freedom that the orthodox common law presumed to exist? Apparently not. Consider the terms of Pound's call for cooperation among lawyers and social and behavioral scientists: "Scientific study of law is no less important to the community than scientific study of medicine. Few diseases threaten civilization more persistently than the manifold forms of antisocial action that we call crimes."260 The caution of the 1911 General Introduction "It need.not be asserted for one moment that crime is a disease"261 - seems to have weakened. From there Pound moved on to his long-standing, trademark, all-purpose prescription for the future of the criminal law: "continuous intelligent bringing to bear upon the fundamental problem and its applications in detail of all that legal and social and medical science have worked out."262 Pound's recognition of "individual freedom" and of "free mental activity" had not, I infer, truly altered his conviction that the most important part of the "fundamental problem" was the concept of "free will" as the basis for criminal responsibility.

Pound aptly entitled his essay The Future of the Criminal $L a w,{ }^{263}$ for it struggled vainly with many of the problems that have played havoc with criminal jurisprudence down to our own times. Pound himself, of course, thought that the best minds, the grandest efforts of all scientists, legal and otherwise, would resolve these problems. Unlike Speranza, he counted law as a science and looked forward to eventual integration of the insights of all the sciences. His reaction against the furthest reaches of executive justice in wartime and its immediate aftermath led him to stress the importance of the consciousness of human freedom, and to insist that that consciousness, when nurtured by social programs that limited barriers - governmental as well as private in nature, gave full sway to human potential as well as to social well being. Pound went so far

259. Id.

260. Id. (emphasis added).

261. General Introduction, supra note 105 , at vii.

262. Pound, supra note 133, at 16.

263. Id. 
on at least one occasion as to refer to what I believe he mainly thought of as the consciousness of freedom as "free will." Witness the dramatic denouement of his chapter, "The Rights of Man," in The Spirit of the Common Law.264

On the contrary the chiefest of social interests is the moral and social life of the individual; and thus individual interests become largely identical with a social interest. Just as in the seventeenth century an undue insistence upon public interests, thought of as the interests of the sovereign, defeated the moral and social life of the individual and required the assertion of individual interests in bills of rights and declarations of rights, there is like danger now that certain social interests will be unduly emphasized and that governmental maternalism will become an end rather than a means and defeat the real purposes of the legal order. Although we think socially, we must still think of individual interests, and of that greatest of all claims which a human being may make, the claim to assert his individuality, to exercise freely the will and the reason which God has given him. We must emphasize the social interest in the moral and social life of the individual. But we must remember that it is the life of a free-willing being. ${ }^{265}$

The language of "claim" appears - and then, just as Pound describes humans as "free-willing beings," is eclipsed. Are you consoled? Was Pound?

We ought not to be surprised by Pound's "slip" - if that is what it was. Led principally by his concern for political liberty, he now saw a "kernel of truth" in the ideas he had attacked for over a decade - but only a kernel. Pound's theory of social interests captured - and domesticated - the element of human freedom, domesticated it but gave it a place so prominent that it is sometimes difficult to see precisely what his comments on the scientific renunciation of the concept of free will amounted to. Still, Scylla and Charybdis had once again been avoided; Pound had safely reached the beckoning shores of deeply humanistic ambiguity.

D.

That ambiguity - or perhaps better, dualism - marked Pound's two most important writings on criminal justice, his Summary in the 1922 Cleveland criminal justice survey ${ }^{266}$ and his lectures, the following year, on Criminal Justice in America. ${ }^{267}$ But the

264. Roscoe Pound, The SPIRTt of the Common LAW (1921).

265. Id. at 110-11 (emphasis added).

266. Roscoe Pound, Criminal Justice in the American City - A Summary, in CRIMmaI Justice IN Cleveland, supra note 87, at 559.

267. Pound, supra note 128. 
two works display other, not unrelated tensions as well. Pound's Summary contained a belated attempt to come to terms with the implications of the new sciences for the prospects of a reformed system of criminal justice; his valedictory lectures, on the other hand, retreated to a mainly historical perspective on current conditions. Ultimately, the historical account that had served Pound so well for so long trapped him, reinforcing his tendencies not to probe deeply into matters for which history was a poor guide and analysis of theoretical underpinnings a necessary next step.

Pound's masterful 1922 Summary integrated insights tracing back to his 1908 piece, Inherent and Acquired Difficulties, ${ }^{268}$ with more recent reflections on the role of the individual interest as an aspect of social interests, and empirical information drawn from the various chapters of the Cleveland project. ${ }^{269}$ The Summary remains Pound's fullest and most cogent account of the problems inherent in criminal administration; its most original aspect is his discussion - engendered, no doubt, by the Cleveland study, itself - of the relationship between the new sciences and the criminal law.

Pound opened his essay with a brief but textured discussion of the problem of free will. Read in the light of Society and the Individual, ${ }^{270}$ Pound's language seems to carry forward his distinction between freedom as a reality and as a state of human consciousness:

Not the least significant discoveries of modern psychology are the extent to which what we have called free will is a product, not a cause, and the extent to which what we take to be reasons for actions are but rationalizings of what we desire to do and do on different grounds. In the administration of justice there are many subtle forces at work of which we are but partially conscious. ${ }^{271}$

268. Pound, supra note 154.

269. Pound, supra note 266. For a brief background to the Cleveland study, see Felix Frankfurter's Preface, in Criminal Justice in Cleveland, supra note 87, at v. See also Gerhiard O.W. Mueller, CrIme, LaW aNd the Scholars: A History of Scholarship IN AMERICAN CRIMINAL LAW 95-101 (1969). Mueller is appreciative of Pound's efforts in providing the inspiration for the Cleveland survey - and, thus, its many successors of the 1920s, which he lists usefully, id. at $96-97$ - but he notes that:

However much the Cleveland Survey may have contributed to uncovering the crime situation in Cleveland, and to the development of criminal statistics, it is impossible to avoid concluding that the only certain conclusion to be drawn from it is that law enforcement will fail if the law is not, or not properly, enforced.

Id. at 98. Mueller described Pound's Summary as "a well-prepared historical sketch, most of which, however, could equally have been produced without the benefit of the Cleveland Survey." Id. at 99.

The Survey was composed of studies of police administration, prosecution, the criminal courts, correctional and penal treatment, medical science and criminal justice, newspapers and criminal justice, and legal education in Cleveland.

270. Pound, supra note 235.

271. Pound, supra note 266, at 561. 
Pound proffered the admonition that one must understand that human beings, legal machinery, and the "complex environment" were formed by "[t]radition, education, physical surroundings, race, class and professional solidarity, and economic, political, and social influence of all sorts and degrees." 272 Complexity reigned: "[W]e must insist on plurality of causes and plurality and relativity of remedies."273 The critique that emerged was not, for Pound, the conventional thrashing of the Puritan notion of free will, but the rejection of a reductionist attempt to match cause and cure one on one. Both individuals and sciences had succumbed to monocausal explanation: "Neither the science of law nor the science of politics has escaped this struggle to master complex facts by giving them a fictitious appearance of simplicity." 274

But once again, the language of freedom reappeared when Pound turned from this causal morass back to the criminal law. There Pound concluded that compromise was necessary between the general security and - familiar phrases - "free individual initiative," "free mental activity." These were of course "claims," "claims" that deserve protection as a social interest in the individual life. ${ }^{275}$ Nothing in the Summary suggests that for Pound such claims stood for actual aspects of human nature rather than states of mind. Nor did Pound repeat his characterization of human existence as "the life of a free-willing being,"276 a phrase whose short life in his work perhaps simply paid fleeting homage to the mysteries of human behavior.

What we do know is that when we turn to Pound's reflections upon the implications of the new sciences for criminal law we no longer encounter the language of "free individual initiative." Nor do we encounter Pound's customary ebullience but, rather, a moving discussion that is hopeful regarding eventual prospects for useful change, though less than sanguine about the process by which that change would come about. Of philosophical conundrums it is not wholly devoid. Traditional criminal jurisprudence, we are told in Pound's now familiar formulaic expression, "thinks of the offender as a free moral agent who, having before him the choice whether to do right or wrong, intentionally chose to do wrong."277

272. Id.

273. $I d$.

274. Id. at 562 .

275. Id at 576-77.

276. See supra text accompanying note 265.

277. Pound, supra note 266 , at 586. 
The theoretical basis for such traditionalism, though, had now been washed away. Here Pound achieved his most sustained assessment - and most implicit endorsement - of the implications of the new science:

We know today that the matter is much more complicated .... We know that criminals must be classified as well as crimes. We know that the old analysis of act and intent can stand only as an artificial legal analysis and that the mental element in crime presents a series of difficult problems. We recognize that in order to deal with crime in an intelligent and practical manner we must give up the retributive theory. But this means that we must largely make over our whole criminal law, which was rebuilt around that theory in the last two centuries, and that work is going on slowly all over the world. . . . We shall achieve lasting results neither by some analytical scheme or rigid system worked out logically in libraries on the sole basis of books and law reports, as some lawyers seem to hope, nor by abandoning the experience of the past, preserved in the law reports, and turning exclusively to administrative, non-legal, expert agencies, which is the hope of many laymen. Pending this making over of criminal law we must expect that many features of the administration of criminal justice will remain unsatisfactory. 278

Finally, Pound addressed the new sciences more directly:

Medical science has all but undergone a rebirth within a generation. Within a generation psychology has risen to a practical science of the first importance, with far-reaching applications on every side. Psychopathology has overturned much that the criminal law of the past had built upon. Indeed, the fundamental theory of our orthodox criminal law has gone down before modern psychology and psychopathology. The results are only beginning to be felt. One result is a just dissatisfaction on the part of the medical profession with what they observe in judicial administration of justice and legal treatment of criminals. In prevention, in criminal investigation as a preliminary to prosecution, in the trial of issues of fact and in penal treatment we have much to learn from the physician and psychologist and psychopathologist. But during the period of transition in which we are learning it and are learning how to use it there will be much experimenting and some fumbling and much dissatisfaction. 279

Too little organization, too little time: No wonder American criminal justice had not yet accommodated the message of the new sciences! But there was indeed a deeper reason, Pound allowed, yet another locally American, rather than universally human problem. The real challenge had to do with altering the traditional habits of American democratic thought and behavior that had long since been ingrained in current administrative practices. On this score,

279. Id at 588. For additional discussion of these themes, see also id. at 645-48. 
the present was bleak, but - Pound seems to be reassuring his reader - the prospects for the future remained bright. ${ }^{280}$

Just how much progress, and of what sort, had Americans so far made? Pound's 1923 lectures constitute his great summing up on the question of criminal justice. The central message of the lectures was not that a determined or compromised will might undermine the conscious belief in human freedom that Pound so highly valued; rather, the message was that Americans gave freedom too much rein, in practice as well as in theory, to suit the conditions of modern life. The data from the Cleveland study had, perhaps, taken its toll. The public order was suffering woefully from institutional infirmities and unabridged individual "self-assertion." The situation called for moderation; Pound pleaded for institutional development and new habits of behavior, individual freedom in accordance with self-restraint. As to deeper philosophical and psychological issues, they played little role in Criminal Justice in America.

Pound commenced his first lecture by observing that, just as crimes should be seen in their specific rather than their general natures, so too were the sources of law specific.

Hence, today jurists approach the law from psychology rather than from metaphysics. They think of the scope and subject matter of law from the standpoint of the concrete desires and claims of individual men in civilized society, not from the standpoint of the abstract qualities of the abstract individual, nor from the standpoint of the logical implications of the abstract individual free will. They consider the desires or claims found to be involved respectively in the individual life ....281

But the claims of individuals could clash, and the purpose of the law was to balance competing claims, whatever might be said about the psychology that accompanied, or generated, those claims. In this, the 1923 lectures are by no means original; Pound had been saying as much for years, as his concept of social interests took hold, evolved, and came to reflect a settled and inspiring confidence. Thus the lectures led up to an assessment of where things stood as of the 1920s, against the background assumption that the law's mission was eminently achievable. The Progressive theme of the practical adjustment between the individual and the social order overwhelmed his account and left little room for consideration of

280. Id. at $645-48$.

281. Pound, supra note 128 , at 4 ; see also id. at $33-34$ (repeating, almost verbatim, his statement of some years earlier: "Our substantive criminal law is based upon a theory of punishing the vicious will. It postulates a free moral agent, confronted with a choice between doing right and doing wrong, and choosing freely to do wrong."); PouND, supra note 264, at 51-52. 
the theoretical basis for a notion of criminal responsibility. In the end, Pound attempted to found juristic criminal justice analysis on an extended assessment of the relationship of political liberty to the needs of the modern state and only glancing reference to the problem of human free will. Let us follow, for a moment, the argument of Pound's final lecture, Criminal Justice Today.

With customary aplomb, Pound assured his audience that "[t] here is no intrinsic reason why democratic institutions should be inefficient."282 Those who persevered to the final moments of his performance may well have concluded otherwise. Pound's retelling of American history brought to the surface conflicting urges in our culture that, at the least, shed doubt on the likely success of our institutions of criminal justice. The tensions between individualism and the striving for order appeared deep, permanent, and fatal to the ideal of institutional efficiency. Pound, himself, ever the optimist, thought Americans who could be brought to reflect on the matter might revise their institutions and their behavior to minimize such tensions, so as to achieve in criminal justice a consciously designed and philosophically uncomplicated functionalism. Such was the uplifting message of Progressivism that the Dean of the Harvard Law School continued to espouse.

In this now little-read work of great sweep and learning, Pound contrasted the democratic ideas and values that flourished in pioneer America to those of his own day. He displayed an appreciation of the former as necessary in their time and place, even as he criticized Americans' tendency to replicate them in a modern, industrial setting, where they produced "false" rather than "necessarily democratic ideals." 283 No stage of the criminal justice process escaped Pound's criticism. At all stages, there was either overreach or under-enforcement; the discretion that was practicable in - and appropriate to - small-town and frontier America yielded arbitrariness and cynicism in modern urban society; Americans' constant recourse to intuitive approaches undermined the potential of the new sciences that might otherwise have produced a rational, unified, and respected system for dealing with the scourge of modern society - the crime problem. For Pound, the remedy was not, simply, more money, more personnel, more structure. It was, rather,

282. Pound, supra note 128 , at 199. Pound's closing discussion reveals doubts as well as optimism; I have set forth in the text what I take to be the main tendencies of Pound's frame of mind.

283. Id. at 198. 
more training, more organization, more system. ${ }^{284}$ Nonetheless, decentralization remained a dominant value as an aspect of our pioneer experience that Pound believed must continue to condition the balance between individualism and collectivism; fear of the specter of Marxism haunted Pound's scholarship. A decentralized political system could be coordinated, scientifically designed, and efficient. Institutions could embody American democratic ideals, if only Americans would achieve an understanding of those ideals that was appropriate to the contemporary context.285

Pound was not entirely negative in his assessment of current conditions. Recent advances in penology drew his praise:

It is enough to say that the prospect here is much more immediately hopeful than at any other point in American criminal justice. We are less in a rut here. A body of trained workers has been growing up which thoroughly understands the problem, its history, and its present status. We are less hampered here than elsewhere by the pioneer tradition and by pioneer institutions. Penal treatment is not unlikely to continue to be characteristically the American field of progress in criminal law and administration. ${ }^{286}$

Alongside these supposed successes of Progressive-Era penology, however, Pound noted that judges at their own discretion often failed to utilize the resources of the police and social agencies. ${ }^{287}$ Moreover, Pound observed:

Penal treatment in America today raises specially difficult questions because the time calls for individualization and the traditional spirit of our law calls for generalized penalties; because our ideas, inherited from the last century, are characteristically humane and stress the individual life, while the times demand greater regard for the general security ...288

Significantly, Pound chose not to address the darker aspects of the new penology, specifically the concept - strongly supported by some deterministic jurists and criminologists of the $1920 \mathrm{~s}$ - of per-

284. Id. at 174-215. It should be noted, however, that Pound never abandoned the suspicion of "system" in the abstract that he voiced in 1912 in Administration of Justice in the Modern City: "One of the inherent dangers of all system and all science is that system and science, which are but means, will be taken for ends and that system will be perfected purely for its own sake." Pound, supra note 189, at 318.

285. Pound, supra note 128 , at 214-15. As to decentralization: "We are not compelled to choose, as has been assumed, between a régime of atomistic individualism or one of state omnicompetence and concentration of all powers and functions in a politically ordered society." Id. at 215.

286. Id. at 198.

287. Id. at 33-35.

288. Id. at 197. 
manent segregation or "elimination" of "incorrigibles" in the "social defense."289

To the successes in penology Pound contrasted the deficiencies of prosecution and trial. He combined a well-informed critique of an outmoded and disorganized prosecutorial bureaucracy with a scathing attack on the politics that produced bargained pleas. To this Pound added the conventional complaint that convictions too often led to appeals and the further claim that the judge "in too many states ... is made quite powerless to control the trial, and the jury becomes an independent tribunal with large scope for disregarding or nullifying the law."290 Here, the vestiges of pioneer justice were deeply embedded and a protective ideology made them resistant to reform: "Distrust of judges, lay magistrates, free rein to counsel in the forum, extravagant powers of juries, an uneducated, unorganized, deprofessionalized bar are urged as democratic, and their supposed democratic character is expected to make up for their manifest inadaptation to the demands of justice today."291 Pound's history of criminal justice in America thus contains a striking portrayal of the distorting impact of the individualistic ethic in our newly industrialized social and economic order. What Pound saw badly strained his deep faith in personal freedom; there is more than a little pathos in his description of the predicament of modernity. The tensions he uncovered were structural and permeated every institution in society. Yet Pound managed to maintain a rationalistic view that Americans could confront and rout what he took to be the deepest drives. Pioneer justice and pioneer attitudes would pass; they were the product of a historical phase, and the necessities of the present would eventually overwhelm current attempts to accommodate them.

Pound's understanding of the "democratic" spirit of his own day was in at least one respect decidedly limited. As I have said, Pound associated that spirit with traditional concepts of political and human freedom, and he assumed that newly gained knowledge regarding the place and role of the individual in the modern social order would eventually reduce what he saw as held-over, and thus immature, strivings for "self-assertion." We have seen, too, that the

289. See sources cited supra note 103. For social-defense writings of the $1920 \mathrm{~s}$ - just after Pound's lectures and before their publication - see HARRY ELMER BARNES, THE REpRession of Crime: Studies in Historical Penology 19-42 (1926); Philip Archibald Parsons, Crime and the Criminal 294-95 (1926).

290. Pound, supra note 128 , at 199.

291. Id. at 199 (emphasis added). 
dangers of the new kinds of knowledge regarding the individual largely escaped him. Pound also failed to consider whether some of the manifestations of the "democratic" spirit that plagued the administration of criminal justice were themselves by-products of distinctively modern ideas. We can detect this particular limitation in Pound's critique when we focus on what had over the years become one of his principal targets, the criminal trial jury. The nature of modern jury behavior reveals tensions deeper than those identified by Pound, and seems to me to suggest that the "rational" functionalism for which Pound campaigned was bound to meet with only partial acceptance.

We have seen that Pound had, from the very beginning of his career, often balanced criticism of the "lawless" jury against the observation that the jury had long operated as a useful safety valve, leavening the harshness and "mechanical" nature of the law, both in civil and in criminal cases, and standing as a bulwark against overweening governmental authority generally. Moreover, some of Pound's early observations recognized that jurors sometimes applied progressive notions in the face of overly traditional legal doctrines. His 1909 review of Parmelee's The Principles of Anthropology and Sociology in Their Relation to Criminal Procedure ${ }^{292}$ suggests that Pound perceived the relevance of this form of jury behavior to what he saw as the law's necessarily cautious approach to new concepts of responsibility. ${ }^{293}$ Pound's comments in this regard may even have infiuenced Speranza, who, from his own special perspective, enunciated the theme of progressive jury behavior in 1912.294 By then, however, Pound had developed a considerably less generous view of the criminal trial jury. I have suggested that his increasing attention to penology led him to emphasize the role of the judge in individualizing justice and to view jury intervention as dysfunctional. ${ }^{295}$ Although Pound never fully abandoned the idea that jurors often acted in good faith to leaven an overly rigid substantive law of crime, ${ }^{296}$ his increasing impatience with this practice was nonetheless obvious.

So, too, was his tendency to characterize the practice as an aspect of "the pioneer attitude."297 In his 1923 lectures Pound put the

292. Pound, supra note 171.

293. See supra text accompanying notes $186-88$.

294. See supra text accompanying notes 70-81.

295. See supra text accompanying note 211-216.

296. Cf. Pound, supra note 266 , at 582.

297. Pound, supra note 128 , at 122. 
jury at the center of his discussion of nineteenth-century pioneer attitudes; nowhere else in the lectures did he dwell on the jury, though he referred to it often enough as possessing "excessive" or "extravagant" power. ${ }^{298}$ Pound introduced the subject with the observation that "[a]s late as 1909 , at the National Conference on Criminal Law and Criminology, an experienced prosecutor pointed out that the old-line American, when he sat upon a jury, was predisposed to release the accused - his first thought was 'let the fellow go.'"299 But his main text for his sermon on the jury - on the "unfortunate effect of pioneer or frontier opinion" 300 - was the law of insanity. Here Pound adverted to Kernan's 1906 address, The Jurisprudence of Lawlessness, which catalogued circumstances in which juries rendered acquittals in accordance with the so-called "unwritten law."301 Many of these cases involved real or perceived "insults to the dignity of a man sensitive as to his "honor," wrote Pound. ${ }^{302}$ "In such cases public opinion justified killing, and until recently juries would not convict." 303 The standard defenses - the "fiction of fact upon which to hang the defense and acquittal"304 were self-defense and insanity. In the latter, alienists produced "extravagant theories," which in time were applied to cases where the unwritten law did not clearly apply; in response, courts and legislators were driven "to warp the law as to insanity and make of it a logical muddle." 305

Pound detailed the "plausible superstructure" of doctrines that came to surround the insanity defense and the countermoves designed to limit the impact of these doctrines. At the center of this discussion of the jury's distortion of the law was legal orthodoxy's definition of a criminal as a person possessed of free will who had freely chosen to do wrong. The expansion of the insanity defense, Pound observed, therefore involved artful ways of denying the existence, in given cases, of free will, and subsequent attempts to rein in the jury often involved "departing from the whole underlying theory of the orthodox criminal law."306 Among the results of

298. Id. at $45,47,154,199$.

299. Id. at 125 .

300. Id.

301. Id. at 126 (discussing Thomas J. Keman, The Jurisprudence of Lawlessness, 29 A.B.A. REP. 450 (1906)).

302. Id.

303. $I d$.

304. Id.

305. Id.

306. Id. at 127. 
this process were differing approaches among various jurisdictions; the widespread impression that the law was "a mass of arbitrary rules"; and the discrediting of expert opinion. 307

All this was passing, but only gradually. Although Pound now saw the "unwritten law" as mainly a nineteenth-century phenomenon, he recognized that its by-products remained, in the form of distrust of testimony, great concessions to the common sense of juries, and resistance to allowing judges to comment on the evidence: "The evil these things wrought lives after them; the good is gone with the pioneer conditions which gave rise to them."308 Still, Pound was hopeful. Referring both to what he considered exotic insanity doctrines and to legal rules adopted to limit their impact, he wrote: "No doubt better theories of criminality will presently make these anomalies obsolete along with the general principles to which they are irrational exceptions." 309

My supposition is that what Pound now termed the "extravagant powers of juries" was only in part a testament to the particular kind of "pioneer ideals" that he had mainly in mind. It perhaps comes as little surprise that, as of 1923, Pound believed that the recent modest reform of penology reflecting a more enlightened perspective on the nature of criminal behavior lessened the need for jury intervention in criminal cases. What Pound failed to consider was the possibility that this Progressive rhetoric itself took a toll on jurors, who, at the guilt-assessment stage, were being asked to stigmatize as "criminal" defendants whose "guilt" was increasingly seen as problematic. Though jurors no doubt adhered to the conventional view that, in principle, most defendants possessed the capacity to act freely, they can hardly always have escaped the sense - subconscious though it may often have been - that, in reality, the particular defendant before them was a victim of circumstances beyond his control. In short, Pound failed to see that the rhetoric and to some extent also the practice of modern criminal justice depended upon an increasingly artificial bifurcation between guilt assessment and sentencing.

After 1909, Pound did not follow through on his embryonic insights regarding the relationship between the leavening role of the jury and the archaic aspect of the traditional concept of mens rea. His mature writings on criminal justice do not advert to the possi- 
bility that the modern jury, in its role as a "safety valve," might sometimes - but only sometimes, and on an ad hoc basis - have intuitively drawn lines, outside the formal rules of law, that allowed the concepts of the new criminology to coexist with more traditional notions of criminal responsibility. ${ }^{310}$ If it did sometimes behave in this fashion, the jury was, in a sense, simply continuing to behave as it had for ages; only now, theory had come to provide a more "scientific" rationale for what this long-standing, practical "Great Pacificator" 311 had earlier done on the basis of its own rough understanding of justice. Pound's concerns about the dysfunctional character of jury power fit well with the concerns of others in the late Progressive Era, when the "irrationality" of jury decisionmaking became a common theme in realist writing. But Pound failed to consider whether particular instances of ad hoc acquittals - or convictions on lesser-included charges - resulted from the influence on the jury of popularized notions of behavioral science, weakening his analysis of the very problems of modern criminal justice he sought to address.

In Progressive America - and beyond - "frontier justice" carried two very different meanings. Pound's relegation of the jury solely to the old frontier was a mistake, but it was an easy mistake to make, for - then as now - jurors themselves may have translated modern questions of human responsibility into archaic ones, or unselfconsciously moved back and forth between new and old. From one perspective, the slayer of his wife's lover vindicated his honor; from another, he had been out of control, which is to say, he lacked the capacity for mens rea. The shift from use of the oldest category, self-defense, or the next oldest, manslaughter, to that of

310. See, e.g., Henry W. Ballantine, Criminal Responsibility of the Insane and Feeble Minded, 9 J.C.L.C. 485 (1919). Ballantine observed that:

The law has failed to take sufficient account of the possibility of different degrees of accountability of those not altogether innocent. At present, the jury fills up the gaps existing in the law of responsibility, and takes into consideration the moral elements and motives of crime. Those who as a result of hereditary taint and unfortunate environment, are mentally and morally degenerate, have not full penal accountability with normal men any more than little children, and if punishable at all, are punishable in a much less degree.

Id. at 498. Note that Ballantine preceded this observation with a statement adopting the conventional paradigm:

The positivist theory is neither practical nor convincing.... [F]or practical purposes the law must accept the common-sense postulate of free will upon which we all act. We assume in normal persons moral responsibility. They are accountable for their acts, and may justly be punished if they fail to control their conduct.

Id. at 494 (footnote omitted). Ballantine was Dean of the College of Law, University of Illinois; this article originated as an address delivered at a meeting of the Illinois State's Attorneys' Association.

311. Speranza, supra note 5 , at 126. 
legal insanity as a fictive device for mediating tensions between formal rules and widespread social attitudes was a development qualitatively different from any that had preceded it. Public outcry over the new convention confirmed that it posed an especially serious threat to traditional concepts of responsibility. The insanity defense provided new theories for old attitudes, and a vocabulary and set of ideas that blended easily with those surrounding the new penology and that together infected the assessment of responsibility in a very wide range of cases. Jurors negotiated the distance between old and new ideas, or mixed them together, applying them willynilly and not always selfconsciously. The jury took its place on the new frontier of justice even as it acted out its place on the old one. "Frontier justice" was a more complex phenomenon than Pound's historically bound and conventional use of the term suggests.

E.

Pound believed that what was most needed to improve the administration of criminal justice was a better educated, less political, and more dominant bench. Armed with knowledge of the new sciences, the judge would oversee a process that met the imperatives of a modern industrial society, one that balanced the needs of order and individualism. The latter would be stripped of unjustifiable and intrusive elements of "self-assertion" but would retain a substance and vitality that accorded with the social interest in the deepest aspirations of humankind and served as a barrier against an allpowerful state. But how did the new sciences and the guilt-assessment function of criminal process fit with Pound's particular concept of individual freedom? Was Pound clear in his own mind about the relationship between this uplifting consciousness of "freedom" and the potentially bleak message of the new sciences that the judge was to learn and apply? Listen one last time to Pound's oft-stated exhortation, in this case the closing lines of his final 1923 lecture:

In criminal law this problem takes the form of quest for a workable balance between the general security and the individual life.... We are not compelled to choose, as has been assumed, between a regime of atomistic individualism or one of state omnicompetence and concentration of all powers and functions in politically ordered society. Our ideas in this connection have been confused by loose use of the words "individualism" and "socialism." The juristic thinking of today must transcend both nineteenth-century individualism and nineteenth-century socialism.... Instead of valuing all things in terms of individual personality, or in terms of politically organized society, 
we are valuing them in terms of civilization, of raising human powers to their highest possible unfolding - toward which spontaneous free individual action and collective organized effort both contribute. As this mode of thirking becomes general, the paths of criminal justice will be made straight. ${ }^{312}$

If Pound ever suspected that the contradictions among the various ideals that he himself espoused might not be resolvable, he never let on. One is tempted to think that Pound well understood these commonplace conundrums of modernity but had focused almost entirely on the problem of achieving a rational and functional social order - an order for which the lessons of social and political science were so very promising. Behavioral science, too, had an important role, especially in the treatment of convicted criminals, who would be rehabilitated so that they could reenter the reformed social order. Pound's focus on the larger social order and on the role of the individual in that order largely, though not entirely, diverted his attention from the individual qua individual, from the problems inherent in the concept of human freedom.

We shall never, $I$ believe, resolve the tensions and ambiguities that appear in Pound's thought. Pound believed that science had seriously undermined the concept of free will and he was among the most prominent in juristic circles openly to proclaim that law should (gradually) abandon that concept as a core requirement for criminal responsibility. Yet, while he emphasized the consciousness of, or the claim to, human freedom, he never brought that recognition together with his position on the mens rea doctrine. Moreover, Pound never outlined what a non-free-will-based system of criminal law would look like; never assayed how in such a régime the reach of the social-defense or therapeutic state would be limited by traditional ideas of due process; and - perhaps most important never speculated about the impact of the open renunciation of true free will on the consciousness of human freedom that, as he saw it, was critical to political liberty, self-realization, and overall social progress. Pound wrote about freedom mainly in the context of procedural guarantees, not substantive law or underlying theory; history was his guide and perhaps his constraining master, political liberty remained his central focus, and the task of balancing the needs of society and the claims of the individual remained his conception of the ultimate goal of criminal justice. The key to achieving this goal, he thought, was adherence to judicial not administrative process, the empowerment and improvement of the

312. Pound, supra note 128 , at $214-15$ (emphasis added). 
bench, which would draw upon, without being superseded by, behavioral-science experts. Given the immaturity of virtually all forms of scientific theory, the integration of legal and behavioral science would come slowly, but meanwhile progress would be manifested by a resettling of the relationship between judge and jury. He seems not to have considered that such a resettlement might be frustrated by the impact of behavioral science, which the law had not yet formally assimilated, on the popular imagination.

How far Pound's private thinking had progressed on the most intractable problems of criminal jurisprudence it is impossible to say. ${ }^{313}$ Publicly, he settled for the platitudes that he was writing in a

313. I have reviewed Pound's pre-1930 papers, including much of his correspondence, but have found nothing that sheds a light different from that indicated in his published writings on the issues with which I am principally concemed. Pound's published writings after 1930 do not reveal substantial attention to these problems or significant development in his thinking about them. For brief commentaries by Pound that reiterated his earlier thinking - as I have described it herein - see, for example, Roscoe Pound, Introduction to RolIIN M. PERkms, Cases and Materials on Criminal LaW and Procedure xiii (1952); Roscoe Pound, The Rise of Socialized Criminal Justice, 1942 Natl. Probation Assn. Y.B. 1, reprinted in RosCoe POUND AND CRIMINAL Justice, supra note 129, at 177.

In 1965, a year after Pound's death, his long-time colleague Sheldon Glueck ventured some comments on Pound's views. He noted that:

[B]ecause [Pound] ... recognized the ethical element in law, he would not have been satisfied with a purely behavioristic criminal law, which removed such concepts as intent, motive, deliberation, premeditation, "malice," and the defense of insanity from the substantive law definitions of crimes and assigned them, as mental concepts, exclusively to psychology and psychiatry.

Sheldon Glueck, A Memoir in Appreciation of the Dean of American Legal Scholars, in RosCOE POUND AND CRImINAI Justice, supra note 129, 1, 22. As I have noted, in his 1909 review of Parmelee, Pound seemed to suggest that the legislature could employ these mental concepts at its discretion, though (I speculate) perhaps more freely in lesser criminal offenses. See supra text accompanying notes 192-94. Pound did not retum to these matters; an early book review ought not to be given much weight. Pound's criticism of the Strasburg decision suggests that, as of 1910, he countenanced legislative abolition of the insanity defense, at least when a convicted person retained the right to examination while incarcerated and, if found insane, could be transferred to an asylum. See State v. Strasburg, 110 P. 1020 (Wash. 1910) (finding a statute that invalidated the insanity defense unconstitutional); see also supra notes 99-100 and accompanying text. Glueck does not seem here to rest his views on Pound's writings; more likely, he wrote on the basis of his discussions with Pound after 1930 (perhaps long after). For further discussion of Glueck's views on Pound, see infra note 452. Paul Sayre, SAYRE, supra note 119, at 170-78, recounts a colloquy between Pound and several students in Pound's seminar (presumably on jurisprudence) that appears to date from 192425, when Sayre was an S.J.D. student at Harvard, or possibly from 1929-30, when Sayre was a lecturer in Civil Procedure at the law school. In the colloquy, Pound states: "Claims are made by human beings; this I consider objective fact. Now the psychological forces in which those claims can also be stated is another matter. Doubtless an important matter and part of the whole juristic picture." Id. at 175 . Pound states:

We necessarily deal with approximations in law and as such they are true. Others may insist on psychological or philosophical forces that will be the ultimate quality but they can't put their finger on these things and usually they don't themselves agree for a very long time on what this ultimate quality is.

Id. Pound continues:

If you will permit me, I would like to add this: Where is the moral element in all this psychology of yours or do you think it's just a question of deterministic psychology and that morals are outmoded and there is no such thing as morals anymore? It's matters 
"period of transition," that "we are learning" the message of the new sciences and "are learning how to use it." 314 He disguised his true thoughts - whatever they were - with the concluding observation that the road to reform would not be smooth: "[T] here will be much experimenting and some fumbling and much dissatisfaction." 315

In this isolated moment, Pound sounded not a little like the Speranza of the Medico-Legal Conflict, who had appealed for calm and for a melding of the best of the scientific and the legal traditions. ${ }^{316}$ As Pound put it, "[T]he experience of the past, preserved in the law reports" - some undisclosed distillation of that experience - would have to inform, or be made to fit with, the new learning of the "expert[s]." 317 Like Speranza, Pound suggested here that the deepest problems of the substantive criminal law could be resolved only by a combination of law and science. Unlike

like this that worry me with the psychological approach as I have seen it developing recently.

Id. Pound told his students that the law had to deal with "actual claims"; he stated that: "All science constantly deals with conventional approximations," and asked: "Are you going to preclude the law from dealing with approximations as every other science does?" Id. at 17576.

It is possible that Pound was conceding here that even the concept of mens rea ought to be based on the human "claim" to freedom, but that matter appears not to have arisen. It appears from Sayre's account that Pound was discussing affirmative claims (e.g. the claim to the right of free speech; the claim to the right to be free from harm) and the reasons why the law ought to respect them. I do not believe that Pound truly confronted here the problem of basing criminal responsibility on the fact that humans made general claims to freedom, that is, of holding a person criminally responsible on grounds he had acted "freely." In that context, I believe, Pound himself doubted the wisdom of recognizing the "freedom" that the law presumed.

314. Pound, supra note 266, at 588.

315. Id; see supra text accompanying note 279. These "platitudes," as I have termed them, did not prevent Pound's essay in the Cleveland survey from being seen as a major contribution, which in many ways it was. See, e.g., Arthur Evans Wood, Methods of Criminological Inquiry, 16 J.C.L.C. 437, 443 (1925) ("[Pound's] philosophic spirit, historical perspective, and scientific insight make it a landmark in American criminological jurisprudence."). Wood also noted that:

Many further difficulties are indicated by Professor Pound in his discussion of the

Cleveland data. From the foregoing it can be seen that he is driving at no merely local improvements, but rather towards a radical reorganization of thought and practice in our system of punitive justice, so as to bring it in accord with modern psychology, psychiatry and sociology.

Id. at 444. Wood, an Associate Professor of Sociology at the University of Michigan, summarized some of Pound's historical and sociological discussions and noted his "call for administrative changes in our police and court systems [and] the more extended use of psychiatric clinics and of probation ...." Id. Wood evidently took Pound's fairly optimistic statements regarding the integration of law, medical and behavioral sciences at face value. Pound's observations were indeed relatively advanced, coming as they did from a legal scholar, despite the fact that Pound tended to skate over the dire implications of the new sciences for the concept of criminal responsibility.

316. Speranza, supra note 5, at 126.

317. Pound, supra note 266 , at 587. 
Speranza, however, even at this isolated moment of insight, Pound seemed to believe that law and science could meld completely, speak with a single voice. Law was different from the behavioral sciences, but it was a science and one that could be perfected by rational selection from among the principles of the two domains. Pound seems never to have doubted that law and science could achieve ultimate unity, never to have conceded that the principles of the latter would always play havoc with those of the former, that the ultimate demand of the human project was adjustment to the reality that, as Speranza had at one point concluded: "Law is one of the Humanities." 318

\section{Pound Eclipsed?: The Conversation OF THE Mm-To-Late 1920s}

For a time, many of those who wrote on criminal justice quoted Pound. His influence was considerable throughout the interwar period - and to some extent beyond. But increasingly it was Pound's sheer presence that drew attention, rather than the historical perspectives and general ideas associated with sociological jurisprudence that had long been center-stage. Pound was well aware of the new currents of the immediate postwar years, including the marshalling of forces for our first great war on crime. ${ }^{319}$ His late writings on criminal justice reflected his concern that individual liberties might be lost, that the coordination of the social order might carry beyond reasonable limits. He had himself been central to the

318. Speranza, supra note 5, at 125; see supra text accompanying note 28 .

319. In the years following the Great War, criminal activity seemed to skyrocket in the United States. 1919 was particularly tumultuous, witnessing the Red Scare, major race riots in several large cities, and the Boston police strike. The fears engendered by these events were intensified by the perceived rise in violence associated with Prohibition. The lawenforcement community and scholars of criminology swiftly responded to these developments: on the national level, Congress created the F.B.I. in 1921, which in turn started the Uniform Crime Reporting program to track the ebb and flow of seven index crimes; locally, police departments took important strides toward professionalization of training and equipment; and academics conducted detailed studies of systems of enforcement.

Pound had been a leader among the academics who had responded to the heightened concerns about crime and the enforcement of public order. As noted, supra text accompanying notes 266-69, he was instrumental in the development and proliferation of the crime commission. These commissions met with varying degrees of success. Some, like the Cleveland Survey, which brought the pervasive practice of plea bargaining and discretionary enforcement to the attention of the populace, were accepted as models for subsequent reforms, while others, like the Wickersham Commission's Report, which brought to the fore important issues of police lawlessness and brutality, lost much of their influence due to the ebb and flow of political fortunes and the institutional power of the law-enforcement community. See generally WALKER, supra note 85, at 161-93 (citing FRIEDMAN, supra note 6, at 272, 360-62). See also James D. Calder, The Origins and Development of Federal Crime ConTROL POliCY: HERBERT HOOVER'S INITIATIVES (1993); ROBERT K. MURRAY, RED SCARE: A Study In National Hysteria, 1919-1920 (1955). 
first of the great crime surveys and had drawn to some extent upon the mass of data it provided. But in the main, Pound was backward looking. He subordinated his understanding of the novel to his construction of the long view, placed the recent within the context of breathtaking historical sweep. Pound wrote generally - and in generalizations. He was indefatigable in promoting empirical research, ${ }^{320}$ but in his own writings he rarely looked at matters up close. New facts were made to fit ideas he had formed over two decades, and those decades themselves were treated as part of a longue durée. So, in due course, was Pound.

The social, political, and legal ferment of the war years and the intellectual movements that resulted are largely missing from Pound's work. They can be found in the writings of those who were influenced by Pound's many contributions, but these are as often as not writings that pay him homage as they pass him by. The true point of departure in criminal jurisprudence and criminal-justice studies was the mid-twenties, just after Pound's audiences had straggled home from his yet-unpublished lectures. It manifested itself in a new school of criminologists who fed on the data of the Cleveland survey and of the many others that followed, and in a number of legal academics who reflected increasing interest in criminal jurisprudence and criminal justice administration. It showed also, of course, in continued concern among medicaljurisprudence scholars - both in and out of the academy - with the longstanding problem of legal insanity. Although all of these groups are traceable to the great cooperative enterprise of the AICLC, the mid-twenties were nonetheless the beginning of the halcyon years, the era of geometric increase in participation, in new initiatives, and in time and money spent.

The new era lies beyond our present story. But some of its first stirrings help draw that story to a close, and to put Pound's part in it in better perspective. Although the characters I have chosen for this last act, scientists and legal scholars, spoke most directly to

320. Pound sought to continue the tangible work of the Cleveland Survey through the fairly successful Harvard Crime Survey of 1926, and his work on the Wickersham Commission's 1929 national survey. The Wickersham survey resembled the Cleveland Survey in its methodology, but with its national scope was a much more ambitious effort. The impact of the commission's product, however, was overcome by the contentious public debate over Prohibition.

From his bully pulpit at Harvard, Pound attempted to create an atmosphere in which legal scholars would take the need for criminal justice reform seriously. He encouraged the development of fellowships for students and professors in the area of criminal law, and was a force behind the creation of Harvard's Institute of Criminal Law in 1929 - an innovation that fell victim to the Depression by 1935 . See Wrador, supra note 88, at 246-48. 
Pound, they were closer in spirit to the young Speranza, for they struggled in earnest with the problem of law and science rather than holding it at bay and wishing it well for the future. Much of what they wrote in the twenties continued discussions that dated from the late nineteenth century, matters that Pound had recognized but largely skirted: the psychology of vengeance, which Pound claimed was deep-seated ${ }^{321}$ but then treated as mainly a transitory historical matter; the problem of criminal responsibility; and the principles of an enlightened penology. Among those who took up these themes were the veteran psychiatrist William A. White, and the neophyte behavioral scientist and legal scholar S. Sheldon Glueck. I first consider a few central aspects of their work from the mid-1920s and then close my story by sketching in the outlines of what I treat as a "conversation" among them and others at the dawn of a new (?) era.

A.

By the time White wrote Insanity and the Criminal Law ${ }^{322}$ he had practiced as a psychiatrist for more than thirty years and become a leading figure in legal-insanity reform circles. ${ }^{323}$ White adopted the psychiatrist's typical compromise position. He recognized the constitutional obstacles to the preferred reform, the substitution of medical or psychological experts for the lay jury in the determination of legal insanity, and argued instead for independent expert witnesses alongside those called by opposing parties and for a liberal test that did not import "artificial" definitions of insanity. White signed onto the 1916 AICLC (Keedy) report, ${ }^{324}$ which fell considerably short of his real preferences. In his independent writings, which culminated in Insanity and the Criminal Law, he pressed his more extreme views in the hope that he could "go over the

321. Pound made this point briefly in 1907 , supra note 155 , at 226-27, and again in 1922 , supra note 87 , at $575-76$.

322. William A. White, Insantty and the Crminal LaW (1923).

323. William A. White, M.D., was appointed superintendent of the Government Hospital for the Insane (Saint Elizabeth's) in 1903, and became an early American supporter of Freudian psychoanalysis. He began teaching at the Georgetown University Medical School that year, and the George Washington University School of Medicine in 1904, as well as developing intern and training programs at Saint Elizabeth's. White's interest in legal questions eventually resulted in pushing for cooperation between the American Psychiatric Association and the ABA from 1927 on. See Tighe, supra note 6, at 436-500.

324. See Keedy et al., supra note 96 (report of the AICLC Committee "A," chaired by Professor Edwin Keedy). White signed on to Keedy's 1916 report, despite reservations about the very use of legal definitions of insanity, because he believed that some reform was better than none at all. The story of the AICLC Committee "A" (and White's role on that committee) is recounted in great and telling detail in Tighe, supra note 6, at 310-81. 
heads" of jurists and appeal directly to the educated public. But he achieved, unwittingly, the ultimate irony: he analyzed jury behavior in terms that made the constitutional right to jury trial seem not merely an aspect of political liberty, but an enlightened response to the deep tendencies of human behavior.

White began by describing crime in primitive society as "infantile" antisocial behavior that "tends to stir similar tendencies in the herd which are under severe repression in the service of civilization and culture." 325 The member of the "herd" who is directly offended rationalizes his punishment of the criminal as getting "rid of sin," but "he is trying to get rid of that sin which he feels is resident in himself." 326 Thus, the criminal "becomes the handy scapegoat upon which he can transfer his feeling of his own tendency to sinfulness"; he "deludes himself into a feeling of righteous indignation, thus bolstering up his own self-respect and serving in this roundabout way, both to restrain himself from like indulgences and to keep himself upon the path of cultural progress." 327 From these "crude beginnings" came modern "concepts of crime, criminals and criminal law." 328

The original negative impulse in response to an offense is vengeance, tending "only to prevent disintegration by destroying the disintegrating factors." 329 Vengeance "takes no account of the possibility of utilizing the forces locked up in these inimical tendencies for constructive ends, it makes no effort to divert these forces into channels of usefulness and creativeness." 330 Punishment in accordance with the prescriptions of the state permitted the expression of personal vengeance, ${ }^{331}$ though this process was transformed over time by the creation of formal institutions designed to determine responsibility. Here White turned to the criminal trial jury:

The jury listens to the evidence that is offered in the case, and hears something of the history of the crime, the conditions which led up to it, its actual performance, and the behavior of the defendant thereafter.... Now the jury takes all of these things into consideration and in doing so represents, or stands for, in miniature, the body of society of which it is a part. ... In other words, the community, through the

325. WHrTE, supra note 322, at 13. For a discussion of White's views, see Hovenkamp, supra note 6, at 565-66.

326. WhITE, supra note 322, at 13.

327. $I d$.

328. Id. at 14.

329. Id. at 16.

330. Id. at 17.

331. Id. at 18-19. 
medium of its selected agents, the jury, in this way projects its own feelings upon the accused, so that from this point of view responsibility stands for something which exists in the minds of the jury rather than in that of the defendant. ${ }^{332}$

The jury "becomes society," or "the herd, in miniature, reduced in size to the minimum number of constituent units that conceivably may adequately reflect its opinions and feelings." 333 Its judgments, White asserted, "can only be understood as biological forces operating as selective agents in a practical manner ... in accordance with the standards prevailing at the time."334 The substitution of the jury for the individual who had been offended "makes for a better organized, more closely knit, and highly integrated structure"; vengeance recedes into the background, though it remains the underlying motive. ${ }^{335}$

The central purpose of White's book was to argue for reform of the legal insanity defense, not the full-blooded reform he preferred, but the Criminal Responsibility Bill proffered by the AICLC committee on legal insanity some years before. Nevertheless, White could not resist pointing out that under his preferred approach, wherein the jury would find whether the defendant had committed the act, and experts would determine whether he had been sane at the time of the act,

the antipathic emotions of the herd would have quite as good an opportunity to vicariate as now. After the prisoner was condemned and the key turned upon him, so to speak, the public would promptly forget him, as now, and any constructive scheme of social therapeutics could then be worked out in peace and quiet and free from the emotional strains that now not infrequently greet an effort on the part of the accused to effect his acquittal by way of the plea of insanity. ${ }^{336}$

White conceded that his preferred scheme was unconstitutional, an objection he regarded as "incontrovertible" given "the standpoint of crime as now conceived, as an offense against society which must be punished." "337 White turned instead to realistic consideration of how the law of insanity ought to be administered, and he produced a strikingly original suggestion.

Two of the most important features of the Criminal Responsibility Bill were its adoption of an eminently flexible insanity test and

332. Id. at 89-91.

333. Id. at 184.

334. Id. at 185.

335. Id at 183-84.

336. Id. at 168.

337. Id. at 169. 
its provision for court-appointed experts in addition to those called by the parties. The two reforms interacted in a significant fashion, according to White: the independent expert, unconstrained by service to one of the parties and, therefore, far more credible than the presumed partisan experts, would serve to get all of the real psychological facts before the jury. As a result,

[the] verdict will reflect such sympathy as the added facts may warrant, sympathy being understood to stand for that quality which enables one to put himself, in his feelings, in the place of the other fellow and so to appreciate, at first hand, his position with reference to all of the facts, his temptations, his weaknesses, his disappointments, desires, ambitions, wishes, tendencies and all that sort of qualities which make him a human being at one with others. ${ }^{338}$

The jury, "free from the impedimenta of artificial and static tests to which they are required by law to adjust their findings, will find the law and the custom much more accurately .... The jury needs ... to be left as free agents through which the law as it exists in the popular consciousness may flow to free expression."339

Thus did White seek to harness the true and organic role of the jury to the cause of reform. At least with respect to the insanity defense - but implicitly in all serious criminal cases - White endorsed the law-finding that he viewed as inevitable and argued for a transformation of the vengeance impulse into an unobstructed flow of human sympathy - a close cousin of both age-old empathy and modern deterministic psychology. Indeed, White went on to claim that the progress of criminal procedure had been away from personal vengeance and toward an "impersonal meting out of justice." 340 Here, White invoked history: "[E]arly in the jury system juries were chosen who knew the contestants or the defendant," whereas now jurors are chosen for lack of that very knowledge "on the theory that they will thus bring a judicial attitude of mind to bear upon the questions at issue." 341 This made it possible to proceed yet further, "to get at the real merits of the broader, and more particular social issues, unhampered by the distorting effects of prejudice or of powerful emotions." 342

It is worth remarking upon the differences between Pound's and White's accounts of criminal justice administration. Pound wrote as an amateur though accomplished historian and professional com-

338. Id. at 209.

339. Id. at 209-10.

340. Id. at 210 .

341. Id at $210-11$.

342. Id. at 211. 
mon lawyer; White wrote as a professional psychiatrist and amateur anthropologist. Pound conjoined deep respect for the "claim" to free will with both a call for reasonable restraint on individual assertion and a professed acceptance of the behavioral scientists' denial that "criminals" in fact freely chose to commit unlawful acts; White was a dyed-in-the-wool determinist. Both envisioned a future in which those convicted of criminal behavior would receive treatment rather than punishment. Pound placed trust in a bench educated in the principles of human behavior: better to leave the power to sentence in the hands of the court, which would be vigilant with respect to convicts' rights, than to surrender convicts up to a cadre of experts employed by the bureaucratic state. White put his faith in experts, who he imagined would exercise independent judgment. White was sanguine about long-term - even permanent - civil commitment of convicts, where that was required by the severity of their illness. Pound skirted that issue, assuming, presumably, that most convicts were treatable well within the time-frames already employed in criminal justice administration. Although Pound looked to a future in which scientific principles of treatment would dominate, it remains doubtful that he accepted White's bleak theory of human behavior. For Pound, the consciousness of freely willed expression, creativity, and self-control remained basic, and his focus on this sunnier side of human psychology leaves his reader to suppose that, by Pound's lights, the incurable were few and far between.

One infers from Pound's account that most offenders were the product of social forces that were subject to change by an educated public. If change did not come easily, it was because the conditions of a modern industrial order were difficult to alter; political will failed. There is little in Pound to suggest he took seriously either White's view of crime as the product of deeply embedded antisocial urges or his view of criminal justice as the group's collective sublimation of its own similar urges. Pound viewed humans as far more rational and malleable than did White, despite the fact that his historical perspective led him to emphasize the influence of "holdover" attitudes.

We have seen that, for Pound, the jury reflected the common view, in both a social and a political sense. It had once played a vital role as a brake on tyrannical authorities and had then served usefully to leaven the overly mechanical common law. The jury had provided discretionary justice in communities that lacked a wellarticulated governmental structure. In all of these instances, the 
jury had exercised an independence that had been rationalized through an ideology of personal freedom, an ideology that lived on beyond the point at which it bore relevance to existing conditions. Modern criminal justice thus required an ideology that justified restraints upon the jury. Pound regarded the continued "extravagant" power of juries as an aspect of cultural lag, explicable in terms of American history and the ideology of freedom that it had inspired. All this would pass: "General improvement will come through better general education in sociology, leading the public to abandon the retributive idea and the man in the street to desist from the demand for revenge ...."343

In Pound's account, the jury had just as often protected the defendant against the "social group" as it had acted out group vengeance against an offending individual. Pound deemed it mainly an institution of resistance to authority, a holdover from times when individual self-assertion was the reigning ideology. We have seen that in writing about the insanity defense, Pound focused on the problem of the unwritten law, railing at the jurors' often wrongheaded sympathy for the defendant. ${ }^{344}$

White, too, recognized juror empathy; but its opposite, a desire for vengeance, dominated his account of typical jury practice. While White believed that the principles of modern science argued against the use of a jury, ultimately he capitulated to a full jury trial in legal-insanity cases, against his better judgment and in the name of constitutionalism. Political liberty now would have its day. But he argued for independent witnesses on the ground that their setting forth all the circumstances surrounding an unlawful act would lead the jury away from vengeance, toward understanding and sympathy. White sought to employ his principles of psychology to produce verdicts of "not guilty by reason of insanity," by virtue of which defendants would be turned over to medical experts for treatment. Thus White hoped to make "scientific" use of the very sympathy that Pound identified with the sham of the "insanity dodge" and the unwritten-law acquittal. According to White, modern psychology and jury trial could be made to go hand-in-hand in this second-best manner.

This tour de force argument for unrestrained testimony to the jury found little support in interwar writings. White's 1923 prescription for reform remained sui generis and one wonders whether

343. Pound, supra note 155, at 239.

344. See Pound, supra note 128 , at 125-28. 
he himself had produced it only as a reductio ad absurdum. Nonetheless, White's stress on the enactment of vengeance and on jury psychology left its mark on the post-Poundian era. White produced an account of criminal justice based upon allegedly universal and deep-seated human motivations rather than upon Pound's relatively local history of the socio-political struggle among individuals and between the individual and the state in mainly the Anglo-American tradition. White's account by no means entirely displaced Pound's, but as a rival theory it garnered as much support from criminologists and legal scholars as did Pound's more tepid sociological jurisprudence.

B.

Pound's account in Criminal Justice in America contributed little to resolution of the fundamental issue of criminal responsibility; with the important exception of his commentary on the legal insanity defense, Pound had said nothing new in his lectures on the relationship between the jury and responsibility. Yet in the short term his work remained influential: it carried forward the basic tenets of his sociological jurisprudence and it provided a concrete, American historical context for the problems that White and others of a similar persuasion tended to universalize. Pound thereby provided tools that other commentators - particularly those who focused on responsibility - could put to good effect.

Sheldon Glueck was among the most important of those commentators. Although he was essentially a behavioral scientist, Glueck possessed a law degree and, by virtue of Pound's sponsorship, was soon to join the Harvard Law faculty. ${ }^{345}$ Glueck both brought the behavioral science perspective into the legal academy and attempted to achieve the media via to which Pound appealed in his "Summary" to the Cleveland study. Glueck also drew inspiration from White's recent work. His 1925 book, Mental Disorder and the Criminal Law, ${ }^{346}$ was at once a stunning synthesis of the

345. Glueck emigrated to the United States from his native Poland in 1903, and became a naturalized citizen in 1920. In that same year, Glueck received an A.B. from Georgetown. Two years later he earned his LL.B. and LL.M. degrees from National University Law School in Washington, D.C., and in 1924 he received his A.M. and Ph.D. degrees from Harvard. Glueck taught criminology in the Harvard department of social ethics for four years before joining the Harvard law faculty in 1929 . Two years later he became a full professor and he was named the Roscoe Pound Professor of Law in 1950.

346. S. Sheldon Glueck, Mental Disorder and the Crmminal Law: A Study in MEDICO-SOCJOLOGICAL JuRISPRUDENCE (1925); see also S.S. Glueck, Ethics, Psychology and the Criminal Responsibility of the Insane, 14 J.C.L.C. 208 (1923). For an excellent discussion of Glueck's ideas, see Tighe, supra note 6, at 382-435. Tighe's account is far more compre- 
insights of his elders and an original contribution to the legal insanity debate. The originality of his work can easily be missed, for Glueck was the paragon of the balanced, pragmatic, common-sense scholar. Although in the 1930s he moved toward a more determinist stance, I seek to capture him as of 1925, when he attempted to shore up Pound's sociological jurisprudence by converting Pound's consciousness of freedom into something like a true free-will-based position.

Glueck's important study recommended reforms of the legal insanity defense that worked within the basic structure of the AICLC proposal but incorporated a series of judicial instructions embodying the view that the cognitive, affective, and conative aspects of the human mind were interdependent. 347 Glueck believed that this approach to avoidance of the rigid and unscientific cognitive test would allow for more accurate jury responses, although he fully recognized that the jury would never be a scientific institution. But that hardly made the jury system second best. ${ }^{348}$ From Glueck's perspective - at least as of the mid-1920s - science could go only so far. Indeed, Glueck sought to breathe life into the traditional legal position on the question of the relevance of free will to criminal responsibility. He effectively glossed the ideas of those jurists more commonly associated with legal orthodoxy, and, by applying the principles of mentalist psychology, he took those ideas to a new level of sophistication. It is not easy to pin down what Glueck meant by human freedom. He tended to circle round the concept, referring alternately to one and then another state of human consciousness. He focused on the problem of moral responsibility more than on human freedom and remained ambiguous about just how the former depended upon the latter. We may briefly trace his steps.

hensive than my own; she effectively places Glueck in relation to the movement for reform of the legal insanity defense. I agree with Tighe that Glueck believed that "man's choices and actions in life were both free and determined." Id. at 393. I have sought to expose Glueck's struggle to make sense of this view.

347. GlueCK, supra note 346, at 118-22, 264-66.

348. Id. at 465-66.

Taking it all in all, the jury of laymen from all decent walks and stations of life, provided, always, that honest and intelligent men do their share of jury service, is as good a device, in our opinion, as could be evolved, for the difficult task of arriving at conclusions on the basis of frequently conflicting testimony. A jury of experts is not pliable enough mentally for the quick and, on the whole, efficient group mind process . . . for experts are liable to be dogmatic, too onesided, each clinging to those theories borne out by his own particular experience ... less tolerant of the views of others.

Id. (citation omitted). 
Glueck began with a description of the subjective notion of responsibility, which "arises from the general opinion, based upon life's experiences, that a person possessed of the ordinary human faculties to an apparently normal degree is capable of acting, and therefore, must, and is by us expected, to act according to an accepted, socially required standard of morality." 349 Of such a person, Glueck continued, "we say that he has a free will ... that in the ordinary affairs of life, he is able to choose the good and avoid the evil." 350 But is this illusory? Glueck conceded that humans could hate, love, forgive, and attribute blame, all without a belief in human freedom. ${ }^{351}$ But

[t]hey do these things because, on the one hand, their innate, instinctive nature prompts them to it, and, on the other, their intelligence and experience teaches them that most human beings have some $c a$ pacity for purposive, creative activity, albeit under the influence of innate, psycho-physical dispositions, or 'instincts', and their emotional accompaniments, or 'motives.' ... If, therefore, we would use the expression 'freedom of will' at all, let us employ it - as some writers of the Mentalist School of Psychology do - as describing man's capacity to act with consciousness of purpose, albeit on the basis of his instinctive nature. 352

We are left with a definition of responsibility that is obtained empirically from observations of human behavior. Glueck's approach to freedom and responsibility was pragmatic, grounded in our common practical beliefs and in our experience of ourselves and others.

It appears that Glueck not only allied himself with the mentalist school, against the "modern radicals," but that he believed that purposive conduct in fact involved choice and creativity in the sense of "some self-direction." In his next pass, however, he sided with the mentalist school over the behaviorist school on strictly instrumental grounds, critiquing behaviorism's failures: "It is difficult to see, on the other hand, how, under a purely behavioristic (mechanicalmaterialistic) conception of the human organism, there is any room for belief in even a shred of free, self-directive, purposive, and to that extent responsible, activity." 353

Glueck's faith in the criminal trial jury seems to have been premised upon a belief that, when properly instructed as to the determinants of nonresponsibility, the jury was relatively well-suited to

349. Id. at 89.

350. Id. at $89-90$ (citation omitted).

351. Id. at 93-94.

352. Id. at 94 (citation omitted) (emphasis added).

353. Id. at 96. 
respond in terms of the presumptions of the law, the practical wisdom of mankind. Here, however, Glueck produced a somewhat different account of responsibility, for he now took account of the psychology of responsibility that characterized society at large. The fit between the presumption of the law (and of mentalist psychology) and the common social instinct, reflected in the "group mind," the jury, was bound to be inexact. With education, the progress of reason, that fit would improve. Glueck melded his approach to responsibility with a description of social psychology that had much in common with White's. He appears to have attempted to harness White's insights to his own less deterministic views. The result was a justification for jury trial that overlapped White's at points, but that departed from it in critical ways.

At the outset of Mental Disorder and the Criminal Law, Glueck asserted that men possessed the capacity for purposive action, even self-direction. In his reprise, he reiterated his view that "[t]he presence of mechanism does not mean that human beings have not some spark of capacity for consciously and creatively guiding their conduct in conformity with legal sanctions,"354 once again seeming to commit himself to an objective conclusion about human behavior. Glueck presented this view as a response to deterministic behaviorists, but then dismissed this debate over free will as largely irrelevant.

But, as we have repeatedly said, it is our belief that praise and blame, the urge to hurt in retaliation, the instinct to self-protection, - these are all concepts that have their tangible illustration and sanction in the psychology of human nature; and, similarly, society's right to selfprotection is found in group psychology, in the primitive urge of the group to maintain itself against those inimical acts of individuals that threaten its very existence. This psychological basis of responsibility is primary; the rest is mere addition, refinement, sublimation, and rationalization. ${ }^{355}$

This appears to give away the store, but Glueck was prepared to argue from the "psychology of human nature" - even from the "primitive urge" - to a concept of responsibility that accorded with the presumption of "educability,"356 by which he meant that if the offender "was able to profit by experience to a more or less normal degree, then he is responsible both morally and to the group, for violating the laws of the group."357 The test for educabil-

354. Id. at 444-45.

355. Id. at 445 .

356. $I d$.

357. Id. 
ity depended, of course, on what the "offender's life history and mental examination disclose."358 But does this mean merely that the individual could be affected by the threat of punishment, or instead that the individual possessed a capacity for actual selfdirection? Taken as a whole, Glueck's work seems to imply the latter.

For Glueck announced two important principles of justice: First, the primary right of society to social protection; second, the recognition of the personality of the offender. ${ }^{359}$ Those principles brought together the many strands of his thinking on criminal justice. Sounding like White, he noted the dangers that attended the first: "particularly atrocious acts stir the group mind, as they do the individual, with hatred, disgust, fear, and a deep sense of outrage," forcing "Justice into a mésalliance with Vengeance."360 Glueck argued that "some toll must be paid to revengefulness and the desire for blood. This is one of the inherent weaknesses [Pound] in all social institutions; and only the solvent of liberal education [Pound again] can aid in its reduction." 361 And here we have the link to the second principle: We have a "duty to suspend judgment upon the actor until we have made an effort to examine into the 'natural history' of [the defendant's] act." 362 Why? Because "[o]ur anger soon cools when we learn that a certain offender really could not have avoided the act." 363 But what does this mean?: When we come to believe he could not? Or when we learn he actually could not? Glueck seems to have meant the latter - in fact to have believed, though he never proved, that sometimes one could, and sometimes one could not, have "avoided the act." True responsibility - and the group's (presumably, the jury's) assessment thereof - depended upon the defendant's capacity for purposive action, on some degree of "self-direction." Whereas White imagined a jury process that allowed for empathy in the context of totally deterministic premises, Glueck envisioned a jury-based determination along lines that complied with, or at least could be understood in terms of, traditional notions of responsibility.

Glueck believed that "fulfillment of all these purposes" required resort to "modern scientific instrumentalities" and to the "more or

358. Id.

359. Id at 446.

360. Id.

361. Id. at 447.

362. Id.

363. Id. (emphasis added). 
less conflicting social interest in the general security, on the one hand, and the social interest in the welfare and opportunity for freedom of individual self-expression, on the other."364 Here, Glueck sounded like and cited Pound, whose sociological jurisprudence really, social engineering - he sought to exemplify. Glueck's integration of Pound's sociological jurisprudence and White's psychology of vengeance was masterful rhetorically, if woefully bereft of philosophical rigor. While superficially Glueck seemed to track White more closely, adding only a much deeper psychology of freedom, the relationship to Pound's work is intriguing. Like Pound, Glueck pushed the abstract doctrine of free will to the side. Unlike Pound, however, Glueck seems to have treated the freedom he associated with conscious purposive action as an "ultimate reality," even though it might appear to us to be a close relative of Pound's "conscious ego" or the mere consciousness of freedom. Nonetheless, whatever internal incoherence Glueck's mid-1920s theory of responsibility might have possessed, its translation into specific terms of group judgment - of jury behavior - filled a critical gap in Pound's account. More important, Glueck's adoption of his entire scheme - even if one takes the underlying concept to be deterministic in nature - was itself an act of "sociological jurisprudence." Pound's work exhibited a superficial form of pragmatism, a Progressive-Era functionalism. Glueck revealed a deeper philosophical pragmatism that took Pound's notion of the consciousness of - or "claim" to - freedom a further step, that coordinated it with group psychology, and that sought to ground justice and responsibility on the overlap among actual capacity of selfdirection, the objective fact of "educability," and the social desire to seek retribution. What was most attractive and ultimately influential in Glueck's account was the protean aspect of his thought. It was open to adaptation to a degree that White's was not. It had, more than anything else, the ring of common sense.

C.

The conversation of the mid- and late-1920s that White and Glueck helped to initiate soon dissolved into a cacophony of discordant voices. The debate over criminal responsibility, to which the issue of free will was central, had increasingly become conflated with the debate over the goal of penal intervention: was it cure of the defendant, protection of society, or both? Little wonder that

364. Id. (citation omitted). 
Pound, who had long before noted the disagreements among the new scientists, as well as between scientists and jurists, resolved to remain above the fray. Safely ashore, out of the dangerous currents, dominating the littoral: so stood Pound. Not so his erstwhile colleague, Northwestern's Dean Wigmore, the first President of the AICLC, and, you will recall, chair the Institute's Modern Criminal Science Series Committee that, in 1911, had called for a scientific approach to the causes and treatment of crime.365 Flush with enthusiasm, the committee had endorsed individualization on a treatment model, never even hinting at a purely social-defense perspective - utilitarian, scientific-positivist, or otherwise - nor, for that matter, even referring to the goal of deterrence. The latter, no doubt, figured as an important aspect of "penal or remedial treatment," but it was "remedial treatment" that seemingly reflected the spirit of the General Introduction. ${ }^{366}$ By the mid-1920s, however, Wigmore's own emphasis had fallen upon the goal of deterrence: he now pointedly distinguished the "point[s] of view" of "remedy or repression," which "[i]n recent years ... have been dimly seen to be destined to lead to more or less conflicting conclusions and results." 367 For Wigmore, among the results was the adoption of more or less conflicting language regarding human freedom.

The occasion for Wigmore's entry into the post-1923 conversation was a symposium on Judge John Caverly's sentencing Richard Loeb and Nathan Leopold to life imprisonment, rather than execution, on grounds of their youth, for their confessed slaying of Robert ("Bobby") Franks in 1924.368 Wigmore protested that "the

365. See supra text accompanying notes 107-12.

366. See General Introduction, supra note 105 , at vii.

367. John H. Wigmore, The Relation Between Criminal Law and Criminal Psychiatry, 16 J.C.L.C. 311 (1925).

368. A Symposium of Comments from the Legal Profession, in The Loeb-Leopold Murder of Franks in Chicago, May 21, 1924, 15 J.C.L.C. 395 (1924-25) [hereinafter Symposium]. For the hearing before Judge Caverly, see Alvin V. Sellers, The Loeb-Leopold Case, WITH EXCERPTS FROM THE EVIDENCE OF THE ALIENISTS AND INCLUDING THE ARGUMENTS to the Court by Counsel for the People and the Defense (1926). On July 21, 1924, Clarence Darrow, representing Leopold and Loeb, withdrew his clients' pleas of not guilty and entered pleas of guilty. Under Illinois law, the punishment for murder ranged from 14 years in the penitentiary to death. If the defendant were found guilty by a jury, then they would determine the sentence; if the defendant pled guilty, then sentencing would be fixed by the court. Darrow entered a guilty plea in order to avoid a jury's outrage, and to gain a forum at which time the defense could " offer evidence as to the mental condition of these young men [and] to show the degree of responsibility they had'." Id. at 11.

At the sentencing hearing, Darrow called a number of psychiatrists to testify as to the defendants' mental condition. The psychiatrists testified, inter alia, that Leopold was a "paranoid personality perhaps developing into a paranoid psychosis." Id. at 24 (testimony of Dr. Bernard Glueck). Loeb suffered from a "disordered" or "split" personality. Id. at 23 (testi- 
reports of the psychiatrists called for the defense, if given the influence which the defense asked, would tend to undermine the whole penal law."369 He attacked the psychiatrists" views as "sheer Determinism," which implied that "[t]here was no choice for us, because all human acts are predetermined ...."370 Wigmore alleged that psychiatrists believed that determinism would "eliminate moral blame, and therefore eliminate penal consequences."371 This, Wigmore stated, was a mistake - and one that even the early Positivist, Ferri, had recognized: "The measures of the modern penal law," said Wigmore, "are not based on moral blame, but on social selfdefense. When there is a weed in your garden, and you cut it down, you do not do this on any theory of the moral blame of the weed, but simply on the theory that you are entitled to keep weeds out of your garden." 372 Wigmore's central point was that "the kingpin of the criminal law" was deterrence theory ${ }^{373}$ and that the psychiatric approach would "lessen the restraints on the outside class of potential homiciders." 374 "Society," Wigmore claimed, "is entitled to use appropriate measures to repress antisocial acts. Society's right of self-defense is equally valid even when the human weed was prede-

mony of Dr. Bernard Glueck). Leopold and Loeb were in the grip of a peculiar "king-slave compulsion" in which "[e]ach boy felt inadequate to carry out the life he most desired unless he had some one else in his life to complement him, to complete him. Leopold, on the one hand, wanted a superior for a companion. Loeb, on the other, wanted some one to adulate him for a companion. The psychiatric cause for this is not be to found in either boy alone, but in the interplay of their two personalities caused by their constitutions and experiences." Id. at 30-31 (testimony of Dr. H.S. Hulbert).

Judge Caverly sentenced Leopold and Loeb to life in prison, with the recommendation that they never receive parole. Caverly acknowledged the impact of the medical testimony stating that:

[T] he careful analysis made of ... the defendants and of their present mental, emotional, and ethical condition has been of extreme interest and is a valuable contribution to criminology. And yet the court feels strongly that similar analyses made of other [defendants] would probably reveal similar or different abnormalities. The value of such tests seems to lie in their applicability to crime and criminals in general. Since they concern the broad questions of human responsibility and legal punishment, and are in no wise particular to these individual defendants, they may be deserving of legislative but not of judicial consideration. For this reason the court is satisfied that his judgment in the present case cannot be affected thereby.

Id. at 319-20. Caverly eventually grounded his decision to incarcerate the defendants on their youth, stating that "the court believes that it is within his province to decline to impose the sentence of death on persons who are not of full age." Id. at 321.

369. Symposium, supra note 368 , at 403.

370. Id. at 404.

371. Id.

372. Id.

373. Id. at 401.

374. Id. at 402 . Wigmore's views regarding the importance of deterrence are stated more fully in John H. Wigmore, The Judge's Sentence in the Loeb-Leopold Murder, 19 ILL. L. ReV. 167 (1924) [hereinafter Wigmore, Judge's Sentence]. See also John H. Wigmore, Juvenile Court vs. Criminal Court, 21 ILL. L. REv. 375 (1926) [hereinafter Wigmore, Juvenile]. 
termined by nature and environment to do just what he did."375 Wigmore cautioned that a deterministic theory could excuse, not just serious crimes, but all deliberate breaches of the law. ${ }^{376}$ Finally:

It is an excellent thing that these scientists have had their day in court thus publicly, because their theories have been going about in books and articles and have begun to affect public opinion. It is time that the issue be squarely faced in the open, before the whole administration of the penal law is undermined. Let public opinion look into the literature on this subject, and learn to discard that false sympathy and dangerous weakening that is apt to arise on first acceptance of the biopsychologic doctrine of Determinism..$^{377}$

Wigmore's comments drew a response from Dr. H.I. Gosline, Director and Chief Psychiatrist of the Dallas Child Guidance Clinic, who declared that the deterrence theory was wrongheaded because, even if it deterred in the short run, it

does not cure, because it only represses, and because it dams back and causes to fester in the body politic. .... Of course [the psychiatric view] is Determinism (with a capital " $D$," as our good friend spells it). But the psychiatrist, who is the determinist, is going to do much more for "social self-defense" than the "measures of modern penal law" now do. ${ }^{378}$

Gosline argued that psychiatrists did not beg indulgence for dangerous criminals, but humane treatment, which in many cases meant psychiatric care. ${ }^{379}$ This, he asserted, would mean that "most of them would stay for life - there would be very little more of this three to five year business"; that, he concluded, would be the "greater deterrent to crime." 380

Wigmore's response to Gosline was somewhat heated. Under the "Cure theory," as Wigmore termed it:

Morality has gone to the bow-wows, and [the] community has passed into a state of drab, cool, materialistic unmorality which would make Life a chill, scientific graveyard and laboratory combined. Let the sociologists speculate as much as they will on the primitive origin and

375. Symposium, supra note 368 , at 404 .

376. Id. at 405 .

377. Id. Perhaps Wigmore also had Clarence Darrow in mind. Darrow was a "popularizer" of determinist ideas; even worse, he made them accessible to jurors. It seems likely, at any rate, that Wigmore had concerns about the impact of the new science on jurors. See Clarence Darrow, Crime: Its Causes and Treatment (1922).

378. H.I. Gosline, Letter to the Editor, The Loeb-Leopold Case Again, 15 J.C.L.C. 501, 504-05 (1924-25).

379. Id. at 505.

380. Id. 
evolution of the Moral Conscience. The great fact remains that it IS. ${ }^{381}$

Wigmore repeated his claim that the psychiatric approach addressed the individual offender but failed to deter the "outside mass."382 Moreover, he posited, that approach was "suicidal."383 He imagined Dr. Gosline "face to face" with a "thug": "What is Dr. Gosline going to do about it now? 'Let me cure you, my sick fellow'? Why, before our worthy doctor has a chance to utter the sentence, the thug will fill him fatally full of lead." 384 The "Cure theory," Wigmore concluded, should be "restricted" to "the very limited and feasible field of, say, juvenile offenses, until it can demonstrate its right to a safe and gradual enlargement."385

Wigmore's invective had been intended, no doubt, for White, who had testified for the defense in the Loeb-Leopold case as a preeminent representative of the psychiatric point of view, a role he played with relish. ${ }^{386}$ But where Wigmore was sardonic, White was condescending. His review of Glueck's book is a case in point. ${ }^{387}$ White greeted Mental Disorder and the Criminal Law with a mix-

381. John H. Wigmore, Comments on Dr. Gosline's Comments, 15 J.C.L.C. 505,507 (1924-25). It is difficult to resist the observation that, for Wigmore, the 1920s were indeed the "bow-wows" period.

382. Id. at 508.

383. Id

384. Id.

385. Id. See Robert Maynard Hutchins, The Law and the Psychologists, 16 Yale L. Rev. $678,689-90$ (1927). Hutchins commented:

One of our leaders [i.e., Wigmore] has lately repudiated the efforts of social scientists to aid us in dealing with crime and punishment, saying that we can determine the preventive effect of jail sentences, fines, and executions by searching our own hearts; no statistics are necessary. Yet his own masterly treatises [on the law of evidence] show on every page that after searching our hearts for centuries we have utterly failed in the hunt: its result has been a mass of conflicting rules, of metaphysical doctrines, of methods of concealing the truth now sanctioned in our courts.

Id. at $689-90$.

Hutchins noted that: "To say that, when the psychologists have anything to offer, the law is ready for them is not enough. If we of the legal profession wait until the psychologists have something to offer us, we may never have it offered." Id. at 689. It is not clear whether Hutchins was referring to Wigmore's commentary on the Loeb-Leopold proceedings or to comments by Wigmore on a different occasion.

386. See John H. Wigmore, To Abolish Partisanship of Expert Witnesses, as Illustrated in the Loeb-Leopold Case, 15 J.C.L.C. 341 (1924-25). Wigmore complained that the "voluntary adoption of the endearing, attenuating epithets 'Dickie' and 'Babe' to designate the defendants reflects seriously on the medical profession. The whole evil of expert partisanship is exemplified in this action of these eminent gentlemen." Id. He claimed they were "adopting epithets calculated subtly to emphasize the childlike ingenuousness and infantile naivity of the cruel, unscrupulous wretches in the dock." Id. White, the first witness for the defense, employed these "epithets." See Sellers, supra note 368, at 15-18. White, of course, was a strong proponent of nonpartisan expert witnesses.

387. William A. White, Book Review, 35 YALE L.J. 779 (1926) (reviewing GLUECK, supra note 346). 
ture of congratulation and caution. It is not clear that he correctly assessed the true purport of Glueck's project, which he appears to have taken as a tactical concession on the question of human freedom as well as on the matter of insanity-defense procedural reforms.

It comes as little surprise that White termed Glueck's recommendations for reform "conservative." 388 At the same time, White deemed Glueck's book to have "the double advantage of being written by a lawyer who has a humanistic point of view."389 $\mathrm{He}$ continued (with Wigmore in mind?):

This humanistic point of view is not needed in order to get over suggestions in line with it to the physician. He is accustomed to it; but the lawyer is by profession and tradition almost without it and he will not be nearly so apt to pay attention to recommendations coming outside of his profession. ${ }^{390}$

White attributed Glueck's "conservative" strategy to his being a lawyer and suggested that Glueck intentionally eschewed "radical" ends in favor of moderation. ${ }^{391}$ "Whichever method of procedure is advocated, the conservative or the radical," White conceded, "is probably a matter of temperament almost entirely."392 Perhaps reflecting on his own recent book, White concluded that "there seems to be no way of telling when to advocate one and when the other."393 White nonetheless felt compelled to respond to Glueck's lengthy discourse on responsibility in frank terms:

The reviewer is rather inclined to believe that we can never solve the question of responsibility, about which so many of the pages of this book are written. ... [R]esponsibility is a conclusion based upon a feeling attitude rather than upon an intellectual one. It is a rationalization of the jury's wishes. ... The fact that it is a fiction may or may not be significant. ... Perhaps a more important question is whether as a fiction it has or has not survived its usefulness. .. . Society is not, or I might perhaps better say should not be, interested in responsibility but only in social assimilability. The simple thing which I have always advocated is to do away with all these inquiries into responsibility, insanity and the like, and merely remove anti-social offenders from society and keep them as long as they remain anti-social.394

388. Id. at 780 .

389. Id.

390. $1 d$.

391. Id.

392. Id.

393. Id.

394. Id. at 780-81. 
Of course, White had faute de mieux fashioned his own compromise two years earlier, imagining a process through which the jury - properly informed by psychiatric experts - would make the inquiry that was constitutionally required. As we have seen, however, White's vision of this process was consistent both with an entirely deterministic perspective - on that he would not compromise - and with rejection of the vengeance motif. ${ }^{395}$ Nonetheless, he clearly believed that his preferred reform program would meet the requirements of retribution and general deterrence: for the "herd," long-term incarceration and treatment would serve roughly the same ends as incarceration and punishment. Like Gosline, White almost certainly assumed that most serious offenders would be confined for longer periods than was the case under current sentencing practice; they would undergo a "constructive scheme of social therapeutics," 396 and the problem of release by psychiatric experts of sane but antisocial offenders whom juries had found not guilty by reason of insanity would be avoided altogether. But these effects were incidental; cure through "treatment" was the true goal. White noted that this was also Glueck's intention; he evidently considered Glueck's concept of responsibility a mere buying of time until society was ready to dispense with that particular "fiction."397 For White, "responsibility" and "vengeance" were correlatives, and he mistakenly read Glueck to think the same. White termed his own views "radical": he was well aware that they flew in the face of constitutional protections and the juristic theory of responsibility.

The reforms for which both pure social-defense enthusiasts and treatment-oriented psychiatric experts campaigned found favor among some legal academics, who nonetheless recognized them as too radical to be implemented. John B. Waite of the University of Michigan, for example, referred to

yet another theory of the objective of criminal prosecution which is coming to the fore and, consummation devoutedly to be desired, may some day be adopted. This theory is, that prosecution seeks no punishment at all, but that it aims to ascertain those who have shown themselves presumably unfitted to mingle in society, with the object that they may thereafter be segregated from society either forever, or until such time as they become fitted for readmission. . . . But this theory is wholly inconsistent with present practices, is at variance with

395. Id. at 781.

396. WhITE, supra note 322 , at 168.

397. Id. "[F]iction" was, of course, White's term. 
the judicial point of view, is a criminological and penological rather

than a legal theory and cannot properly be here considered. ${ }^{398}$

Unfazed by such warnings from even the more receptive of legal academics, White carried the campaign against the judicial point of view into the heart of the enemy camp in August, 1927. "Law and medicine," White stated at the annual meeting of the American Bar Association in Buffalo, share common aims, but "have come to talk as it were different languages"; "they have thus far been unable to get together largely because they do not understand each other."399 Many in his audience may well have felt that they understood each other only too well, but White, who had begun by noting the importance of the fact that the ABA had "set aside a session to be devoted to psychiatry," 400 proceeded to lecture his lawyerly audience as though it was yearning for instruction on where it had gone so wrong.

At the center of White's criticism of the practices of the criminal law was his observation that "the vengeance motive ... still functions but under a disguise, namely the disguise of deterrence, which makes it seem like something else."401 Thus lawyers might say and believe - that the law looked to the welfare of society rather than to the punishment of the morally culpable offender, ${ }^{402}$ but they only deluded themselves. Everything pointed to this conclusion: the language of the law; the nature of trials; the failure to examine each individual offender in a detailed fashion; the prevailing approach to penology. The claim that the end of the law is simple deterrence, and not vengeance, was a mechanism familiar in psychiatry: "[T]raditional beliefs and methods of procedure . . . in order to be retained are given the odor of sanctity ...."403 White

398. John Barker Waite, Irresistible Impulse and Criminal Liability, 23 Mrct. L. Rev. 443,454 (1925). Waite's position is, in fact, difficult to pin down. Leaving aside theories that he deemed premature (though "devoutedly to be desired"), he adopted the view that even in (or especially in) a deterministic world, nearly all people could indeed be determined in their behavior by the fear of punishment and applied this perspective to his analysis of the irresistible impulse test. Id. at 470-71. As to the "desired" theory, Waite seems to have stood somewhere between White and Wigmore. Wigmore's deterrence-based view was premised on punishment, in the social defense, if not on the basis of retribution. It certainly went beyond mere "segregation" of the offender. White favored "segregation," but on the basis of a theory that does not seem to reduce to what Waite termed a purely "criminological and penological" view. For a discussion of Waite on some of these points, see Hovenkamp, supra note 6 , at 572-74.

399. William A. White, Need for Cooperation Between Lawyers and Psychiatrists in Dealing with Crime, 13 A.B.A. J. 551, 551 (1927).

400. Id.

$401 . I d$ at 554.

402. Id. at 552 .

403. Id. at 554 . 
went so far as to characterize the convicted offender as a "scapegoat":

$\mathrm{He}$ is an individual whose personality has been built up in a way to explain the crime with which he is charged, and of his personality only the more superficial things ever get into the picture. In fact it becomes necessary to build up such an artificial personality if the emotion of vengeance is to be loosed against him. If one really knew the personality of the average criminal, how pitifully inadequate it was to cope with the situation in which he found himself and how logical and understandable his conduct under all the circumstances of the situation really was, it would be very difficult to get oneself into a state of mind that permitted the severity of punishment which the law often requires..$^{404}$

White was careful to remind his audience that he endorsed society's right to segregate dangerous antisocial actors, which meant "largely ... doing away with fixed sentences." 405 In counseling the "elimination of punishment as a vengeance motive," he justified "its retention only if used for definitely constructive ends for conditioning conduct." 406

White's speech drew a mocking response from Wigmore. In an editorial in the Journal of Criminal Law and Criminology, 407 Wigmore noted the psychiatrists" "favorite attitude": "Punishment is mere revenge, atavistically perpetuated in our law; all that mere terminology should be abandoned."408 Had psychiatrists studied the philosophy of the criminal law they would have learned that it was no longer based on revenge. Wigmore listed its five purposes: to "treat the committer - thus if possible to cure or improve him"; to "segregate the committer - so as to protect possible other victims"; to "reaffirm publicly the moral code for the community"; to "frighten other potential committers of similar deeds"; and to "satisfy occasionally the crude public demand for revenge - this in those few cases only where there would be danger of lynching if courts did not act." 409

Reiterating his point that deterrence was aimed, not at the individual who has already committed a crime but at the large unarrested public, Wigmore scornfully adjured his intended audience -

404. Id.

405. Id. at 555 .

406. Id.

407. John H. Wigmore, Doing Away with "God and Other Religious Terminology," 18 J.C.L.C. 493 (1928).

408. Id.

409. Id. at 493-94. 
"Search your own memory, Mr. Psychiatrist!"410 — to consider why they did not speed, or why they did not follow through on the thought that they might try to bribe a policeman who stopped them for speeding. "It was the Deterrence theory working on your normal and respectable mind ... deep down in your Freudian subpsyche. It was Fear! It was Deterrence!"411

Nothing Wigmore said on this occasion was necessarily inconsistent with a determinist perspective. He equated the "moral code" with the "moral emotions of conformity to the social principles of good and bad," but he adduced no particular basis for these.412 Rather, Wigmore attacked psychiatrists generally, and White in particular, whose charge that vengeance functioned under "the disguise of deterrence" infuriated him; it also indicated to him that White did not truly believe in holding antisocial offenders for so long as necessary to cure them as a general deterrent. Wigmore must have read White to mean that the law looked only to revenge, hence only at the "committer," and he overlooked the possibility that White thought society at large would learn a lesson from the "conditioning" of offenders until they were cured. In light of Wigmore's diatribe of three years earlier, however, it is tempting to think that Wigmore also objected to the psychiatrist's call for effective decriminalization, believing that such a perspective undermined special and general deterrence, not least because it destroyed the true basis of the "moral code," the belief in free will.413

410. Id. at 494.

411. Id. at 494-95.

412. Id. at 493.

413. Wigmore affirmed the importance of belief in the "moral code" in Wigmore, Juvenile, supra note 374 , at 376 :

[Social workers and the psychiatrists] are going wrong. They are... virtually on the way to abolish criminal law and undermine social morality. . . . Every day, in a thousand American courts, the judge is voicing the law, which says in thunder tones that go far beyond the courtroom walls: "Thou shalt not kill; for killing is wrong. Thou shalt not steal; for stealing is wrong. Thou shalt not cheat; for cheating is wrong." And the rest of the Commandments. The courtroom is the only place in the community today where the moral law is laid down to the people with the voice of authority. The churches do not do it. The clubs do not do it. Public opinion has no concrete and authoritative organ. The court alone does it, through the criminal code.

But the social workers and the psychologists and the psychiatrists know nothing of crime or wrong. They refer to "reactions" and "maladjustments" and "complexes."

In a later editorial, Wigmore returned to the theme of deterrence; one must distinguish between those who are deterrable and those who are not. One school of psychiatry ("a loud and powerful one") viewed "all crime [as] analogous to a disease ... and that therefore the penalties of the criminal law are psychologically futile." John $\mathrm{H}$. Wigmore, Better Not Park Therel You're Liable to Get Pinched, 22 J.C.L.C. 5, 6 (1931). This school fails "to reflect on the psychology of the normal person - those who constitute $99 \%$ of the population." Id. Of these persons,

Some ... are so made that they would execute this anti-social self-will sometimes only. And some persons are so made that they would execute this self-will every time. That is, 
Wigmore's response to White drew its own response from the former Columbia Law School Dean and veteran criminologist, George Kirchwey.414 Kirchwey described Wigmore's editorial as "a vastly amusing exercise in logomachy," but opined that "it may be doubted if he was entitled to all the fun he got out of it." 415 For "if punishment under whatever name survives, whether for the avowed purpose of deterrence or, as Dr. White would have it, as 'a definitely constructive' means 'of conditioning conduct,' will it not still and with the same effect teach the lesson that the way of the transgressor is hard?"416

There was, however, more to the disagreement between Wigmore and White. Kirchwey allowed that

we can sense a profound conflict of policy [moving beneath the "topmost froth of" their "thought."] The slogan of modern penology is the individualization of punishment - a parlous doctrine, fons et origo of the hopes and fears that underlie the controversy. Everyone accepts the doctrine in principle as a matter of justice and of social expediency. Applied, as the principle, for the most part, has been, casually, sentimentally, ignorantly, it has nevertheless been accepted as a necessary mitigation of the stern justice of the law. But what will become of the stern justice of the law when the principle of individual treatment comes to be applied intelligently, systematically, in all cases? 417

Kirchwey insisted that "Dr. White and his fellow psychiatrists" aim at just such a goal; moreover, he supposed that they might "end by persuading us all - all of us, at least, who have the courage to face the facts and the intelligence to apprehend them - that there is no

they would if a motive still more powerful did not come in to restrain them, viz., the fear of the law's penalty.

Id. Wigmore's language is consistent with the view that the "selfish will" is a biological or psychological fact. The argument, then, was merely one between determinists, or between the concept of "disease" and the concept of "anti-social" behavior. Without the "moral code," life would be dangerous. Why, however, would it be any more "drab, cool, [or] materialistic"? See Wigmore, supra note 381 .

414. George W. Kirchwey, Punishment and Other Penal Terminology, 19 J.C.L.C. 6 (1928). [Kirchwey's contribution appears to have been untitled; the title I have supplied appears, in fact, to have been supplied by the journal's editor as a column header under which Kirchwey's comments were placed.] Kirchwey spent the early part of his career practicing law in Albany, and then teaching at the Albany Law School and eventually Columbia University, where he was the dean of the law school from 1901-10. During this period he became interested in rehabilitationist penology, was elected to the New York Prison Association's executive committee in 1907, and served on the New York State Commission on Prison Reform from 1913-14. Kirchwey was temporary warden of Sing Sing in 1915. Retiring from Columbia in 1916, he joined the New York School of Social Work the following year and served as the head of its department of criminology from 1918-32, when he retired.

415. Id. at 6.

416. Id.

417. Id. at 6-7 (emphasis added). 
crime without its extenuating circumstances and no criminal who is not, in a real sense, the victim of his fate." 418 "At any rate," he said, "it will spare us the sentimentality which goes side by side with the cruelty of the present system." 419 Kirchwey understood - or perhaps merely chose to gloss - the psychiatric perspective as a form of social defense, and this he thought a good exchange for the present system of individual responsibility. "We may hope to embody in practice John Dewey's pregnant maxim: 'Causes are not excuses." 420 Kirchwey concluded his response to Wigmore with a clear endorsement of White: "This may be cold-blooded, it may not be 'justice,' but it should be far more effective as a social policy than our present system of 'justice tempered with mercy." "421

Shortly after Kirchwey's brief note appeared, Pound took the stage once more, this time to deliver the main address at the American Psychiatric Association, Science and Legal Procedure (1928).422 While nothing in the lecture proves definitively that Pound was aware of the interchange between Wigmore and White, it was relevant to White's address to the legal profession the preceding year in several ways. The paper was vintage Pound. It reveals his hostility to the idea of "the vicious will," once again historicizes the emergence of will theory, and says nothing about deep-seated retributive urges. ${ }^{423}$ In it Pound returned to the theme that characterized his earliest work and that, I believe, largely conditioned the tenor of his subsequent writings. Echoing the perspective of Sheldon Amos, to which he had accorded prominence in his 1903 Outlines, ${ }^{424}$ Pound instructed his audience:

We may not expect to have a system of criminal justice far in advance of what the public can and will understand and believe in. We must make the demands of science clear and familiar to the public before we may, in deference to science, tear down much to which men are accustomed or build up much that is new. ${ }^{425}$

Science, Pound said, was advancing rapidly and in a state of flux. This made it "difficult to make an adjustment of legal conceptions and legal institutions and legal practices to scientific knowledge ... which will at once be intrinsically sound and commend itself to pub-

418. Id. at 7 .

419. Id.

420. Id.

421. Id. at 7.

422. Roscoe Pound, Science and Legal Procedure, 8 AM. J. PsychIATRY 33 (1928).

423. Id. at 38-39.

424. See supra text accompanying notes 139-42.

425. Pound, supra note 422 , at 36. 
lic understanding." 426 Pound reminded the psychiatrists that "most people were brought up with certain ideas about criminals which speak from the society of the past," by which Pound meant "a pioneer or rural society." 427 He now alleged that even the great Progressive-Era advances in penal science and institutions had come before "the public had ... . [been] taught what such things mean." 428 The result, Pound said, was "a reaction in the last decade which threatens to do not a little injury to some of these new devices and to retard greatly the development of others." 429 Pound stressed his life-long vision of the law's imperative: in the interests of "certainty, uniformity and equality, to do in the next like case what it did in the one before." ${ }^{430}$ Thus, he said, Aristotle had noted the great difference between the legal and medical practices: in law, the method of trial and error was greatly limited; if medicine followed the law, the physician would be required to "prescribe from a book, designated by the state, and according to rules laid down in that book." 431 Experimentation of the sort expected of physicians is precluded for trial judges by the needs of "the general security."432

Was Pound replying to White's critique of "the present system," with its short list of remedies and stereotyped conceptualizations of behavior? Perhaps; but he came little closer than he had in 1922-23 to addressing the difficult questions of vengeance and responsibility, and their relationship to principles of penology. When, at the close of his address, he turned to the problem of individualization, he stressed the importance of the role of the judge over that of the behavioral scientist. ${ }^{433}$ This reaffirmed his belief that the traditional principles of political liberty that governed the law would, even in an enlightened and reformed system of criminal justice, continue to limit science's encroachments on jurisprudence. Pound

\section{Id. at $36-37$.}

427. Id. at 37 .

428. Id.

429. Id. Pound sounded the same note a year later:

Men have come to fear that in our zeal to secure the individual life we may relax the hold of society upon the anti-social, impair the fear of the legal order as a deterrent upon anti-social conduct, and release habitual offenders prematurely to resume their warfare upon society. On the other hand, it has seemed to threaten the security of the individual life by committing too much to the discretion of administrative officers.

Roscoe Pound, Foreword, 42 HARV. L. REV. 297, 298 (1929) (introducing Sheldon Glueck and Eleanor T. Glueck, Predictability in the Administration of Criminal Justice).

430. Pound, supra note 422 , at 36.

431. Id.

432. Id.

433. Id. at 47. 
thus continued to straddle the domains of the traditional common lawyers and the new behavioral scientists, invoking the latter's central claim but tempering it with a gradualism that would shield the former from the drastic consequences of determinism's full victory. A man for more seasons than most, Pound achieved only the semblance of a coherent, practicable program, satisfying himself that his principles of gradualism would hold in place the conflicting urges of the day; self-consciously shielding his chosen profession from the dangers of the looming abyss. His recognition in 1928 that the growth of penal science had occasioned a divide between scientific ideas and the understandings of the common man occasioned an important partial retreat from the cover of bifurcation. The principles of sentencing should not, he now counseled, depart too radically from those of the traditional assessment of guilt.434

Within months of Pound's address to the American Psychiatric Association, Judge Benjamin Cardozo spoke in somewhat different terms to the New York Academy of Medicine.435 Cardozo discussed New York Governor Alfred Smith's 1928 legislative message, in which Smith recommended that the New York Crime Commission study the reform put forward by many "students of criminology": "that [in Cardozo's words] the whole business of sentencing criminals should be taken away from the judges and given over to the doctors. Courts, with their judges and juries, are to find the fact of guilt or innocence."436 Smith had endorsed such a reform, which, of course, aligned him more closely with Glueck than with Pound.437 Cardozo, himself, remained agnostic about the project, ${ }^{438}$ which, in itself, placed him well beyond Pound, who religiously guarded the bench's control over sentencing. He registered agnosticism as well about the deterministic premises of some reformers ${ }^{439}$ but that, he said, did not "detract from the fullness of [his] belief that at a day not far remote the teachings of the bio-

434. Id. at 37. It is difficult to say just how strongly Pound felt about this. In his Preface to CrImmal Justice in AMerica, dated November 7, 1929, Pound noted that "[i]n the years that have intervened [i.e., since 1923] much has happened, but little, I think, to change the main lines of the picture or important details." See Pound, supra note 128.

435. Benjamin N. Cardozo, What Medicine Can Do for Law, Address Before the New York Academy of Medicine (November, 1928), in BENJAMIN N. CARDOzo, LAW AND LITERATURE AND OTHER ESSAYS AND ADDRESSES 70 (Fred B. Rothman \& Co. 1986) (1931).

436. Id. at 79.

437. Id. at 79-80.

438. Id. at 84. ("I have no thought in all this to express approval or disapproval of the project of withdrawing from the court the sentence-fixing power.").

439. Id. ("One may see a wise reform there without acceptance of the creed that virtue and vice are not spiritual essences, but high-sounding synonyms for the hormones of the body."). 
chemists and behaviorists, of psychiatrists and penologists, will transform our whole system of punishment for crime."440 In the then and there, though, Cardozo cited Glueck's view that humans had " some spark of capacityfor consciously and creatively guiding their conduct in conformity with legal sanctions," "441 and endorsed the view, similar to Wigmore's, that punishment was necessary to deter both "the man who is criminal at heart" and "others who in our existing social organization have never felt the criminal impulse and shrink from crime in horror."442 $\mathrm{He}$ concluded this section of his address to the members of the Academy of Medicine in terms that resonated with the language of Speranza and Pound:

The methods, the humane and scientific methods, that have thus prevailed will spread to other fields. This is your work, I am persuaded, as much as it is ours. Your hands must hold the torch that will explore the dark mystery of crime - the mystery, even darker, of the criminal himself, in all the deep recesses of thought and will and body. Here is a common ground, a borderland between your labors and our own, where hope and faith and love can do their deathless work. ${ }^{443}$

Were they consoled? Was Cardozo?

Precisely at this moment, Pound's protégé and quasi-fellowlegal-traveler, Glueck, began the journey that was to move him ahead of Pound and Cardozo - on the road to the behaviorist abyss. Glueck did not entirely renounce his concept of human freedom; but he now began the task of severing the question of free will from the domain of criminal justice. In 1928 he proceeded only so far as to emphasize the importance of the sentencing stage, which would be dominated by the personnel and principles of behavioral science. 444 In 1930, at the moment of publication of Pound's increasingly backward-looking Colver lectures, Glueck reaffirmed his faith in bifurcation, perhaps seeking to assure his behavioralscience colleagues that the fact-finding process would, in practical effect, serve only to determine that an offender had committed the

440. Id. at 86 .

441. Id. at 88 .

442. Id.

443. Id. at $94-95$.

444. Sheldon Glueck, Principles of a Rational Penal Code, 41 HARv. L. Rev. 453, 475 (1930). Glueck also stressed the importance of differentiating the "guilt-finding phase" from the "treatment (sentence-imposing) feature of proceedings." Id. His article both struck a note that appears to rebut White - "No thoughtful person today seriously holds this theory of sublimated social vengeance," id. at 456 - and explicitly endorsed White's view that "[t] he criminal thus becomes the handy scapegoat ...." Id. at 458; see supra text accompanying note 356. 
act, for which the appropriate form of "treatment" would later be determined. 445

Some six years later, Glueck moved a crucial step further along the way from law to science. 446 While reiterating his belief in humans' capacity for purposive behavior, ${ }^{447}$ he now conceded that "society has not yet invented an instrument for diving into a man's mind and determining the exact capacity for self-direction, selfcontrol, and selective introjective power that he or the fictional 'reasonable' man of the law possesses." 448

More to the point, Glueck now argued, a criminal act indicated that the actor had at that moment lacked such a capacity:

Thus the criminal act occurring at any given time is the outcome of constitutional and acquired personal and social forces. It shows that the individual's power of resistance, or self-guidance, or selective choice and introjection of bits of the environment, has been overbalanced by the strength of the other circumstances. ${ }^{449}$

Glueck concluded that for all criminal cases, not just those involving insanity, these overmastering forces could be discovered and taken into account during the second stage of the process. Glueck made it clear that under his proposed scheme the jury would still determine the mental element of the crime; but the sentencing function, "different in methodology and aim,"450 should be "entrusted to a tribunal to be composed, say, of a psychiatrist or psychologist, a sociologist or educator and the trial judge."451 Almost all the way from law to science but not quite. While renouncing the relevance of free will to the problem of criminal responsibility Glueck had nonetheless maintained the jury for determination of guilt, which from the jury's point of view might well involve the presumption of human freedom. Even as a scientist, Glueck had wittingly or otherwise - vindicated the true imperative of the law through a consciously-embraced prescription for formal bifurcation of the criminal process.

$$
\text { * * * }
$$

A full three decades later, in his memoir of Pound of 1965, Glueck enlisted him as a full fellow-traveler on the journey to a new

445. Sheldon Glueck, Significant Transformations in the Administration of Criminal Justice, 14 MENTAL HYGIENE 280, 297 (1930).

446. Sheldon Glueck, CrRME ANd Justice (1936).

447. Id. at 180 .

448. Id. at 181.

449. Id. at 180 .

450 . Id. at 225 .

451. Id. at 226. 
system of criminal jurisprudence. ${ }^{452}$ If Pound actually ever made the trip, as opposed to envisioning such a system in prospective terms, he never said so in his writings. But Glueck's views on what his colleague of thirty years "probably" thought as of the 1920 s must be considered in the light of the fact that in 1925 he had himself produced an elaborate defense of the orthodox concept of jurybased determination of criminal responsibility.

452. Glueck, supra note 129 , at $22-23$.

It is probable that Pound's practical position on the role of the substantive criminal law in a society of advancing scientific knowledge and humanitarianism was to regard the objective of the proof of "guilt" as a strictly technical legal one, without any necessary implication of moral guilt. This would lead to the ascertainment of legal liability under existing methods of trial before the traditional criminal court; but once the legal status had been determined, the defendant would be turned over for sentence and determination of a correctional and treatment plan in the individual case to a board of specially qualified experts in the behavioral disciplines, presided over by a judge. Always, there would be careful legal protection of the convicted offender against arbitrary treatment and for the purpose of prescribed periodic review of the case to determine progress and to guarantee release from legally controlled custody when the offender had sufficiently improved in attitude and predictable future behavior to be no longer reasonably deemed a threat to society.

Id.

It is worth noting Glueck's observation in the same passage that Pound "recognized the ethical element in law." See supra note 313. Glueck's remarks here might reflect Pound's views as they developed after 1930 . Pound's earlier views remain murky on the problem of guilt-assessment, though his rejection of free will might be taken to imply the scheme Glueck outlines. My main point is that Pound never discussed the implications of such a transformation of the trial and certainly, as of the 1920s, would have consigned that transformation to the distant future. As to sentencing, Pound jealously guarded the position of the judge. The "board of specially qualified experts" presided over by a judge was Glueck's idea, though he might over time have brought Pound around to it. See supra note 451 . As to a completely open-ended period of "legally controlled custody," nothing in Pound's pre-1930 writings clearly adopts this essentially positivist, treatment-based social-defense-based position. Perhaps Pound thought that society would eventually reach the point where such a procedure would be safe, but the impression Pound leaves is that parole, even on the strictly reformist principles outlined by Glueck, should function to release an offender short of an otherwise fixed maximum. All in all, Glueck's speculation seems plausible but more akin to what he himself espoused than to what Pound - given his more traditional common-lawyer's stance on political liberty - seems to have been able comfortably to accept.

If anyone knew what the post-1930 Pound really thought, it ought to have been Glueck, but Glueck's 1965 essay provides little sense of the early Pound and none at all of Pound's development. Understandably, Glueck described Pound in general terms, never really attempting to explain him. Glueck might have underestimated Pound's intuitive resistance, on due process grounds, to the kinds of reform that Pound's views on free will seemed to imply. He did not make sufficient room for Pound's very powerful endorsement of the consciousness of freedom and thus failed to appreciate the tensions in Pound's (at least pre-1930) criminal jurisprudence. He did not assess the full importance of the fact that Pound was led by his historical approach to view both the concept of free will and the "retributive theory" as, largely, aspects of the American "democratic" spirit, hardly a sound foundation for holistic solutions to the deep problems of criminal justice. Finally, Glueck appears to have been misled by Pound's optimism about the eventual accommodation between law and science into mistaking a fundamental inability seriously to face the future for a merely pragmatic decision to leave the future to others. In short, whatever Pound became (or was willing to agree with in private), the Pound of the Progressive Era was a more complicated, more interesting, and more skeptical figure than Glueck captured in his otherwise effective tour d'horizon of Pound's contributions to criminal justice studies. 
D.

Whatever the virtues of the differing attempts of White and Glueck to resolve the longstanding problems of freedom and criminal responsibility, their 1923-25 contributions had clearly commenced an era of greatly heightened concern within the legal academy regarding the implications of the new sciences for the administration of criminal justice. Over the several following decades, legal academics became more active participants in the ongoing debate over criminal responsibility, moving outward from their longstanding contribution to the problem of reforming the insanity defense. In doing so, they participated in an exchange with behavioral scientists - including the new cadre of deterministic criminologists ${ }^{453}$ - that produced the first returns from the endeavors for which, in their differing ways, Speranza and Pound had called.

The jurists' side of the early years of this exchange - from 1923 to 1939 - thus witnessed vigorous debate over the aims and purposes of the criminal law, including, at long last, focused legalacademic discussion of the relevance of the concept of free will to the problem of criminal responsibility. It saw, too, the first truly historically informed analysis of the doctrine of mens rea; ${ }^{454}$ an examination of the practice of prosecutorial discretion against the background of the decades-long increase of guilty pleas and decline in recourse to jury trial; 455 an enterprising study of the role of jury nullification of overly harsh sanctions in eighteenth- and nineteenth-century England; 456 and a vitriolic attack on the retributive idea of punishment that speculated about the eventual recourse by society to benign "elimination" of incorrigibles in the name of the social defense. ${ }^{457}$ The influence of some of these and of yet

453. Perhaps the most important foundational work of this new "school" was Sutherland's Criminology. EDWIN H. SutHerLAND, CRIMINology (1924). Sutherland's book was followed almost immediately by studies by, Barnes, Gillin, and Parsons. See BARNEs, supra note 289; John L. Ginlin, Crmminology and Penology (1926); Parsons, supra note 289. Of the numerous books of the 1930s, Nathaniel Cantor, Professor of Criminology at the University of Buffalo, produced two of the more significant and the more thoughtful. See Nathantel F. Cantor, Crime, Crmminals, and Crmminal Justice (1932); Nathaniel F. Cantor, Crmme and Society: An Introduction to Crimmology (1939). The "exchange" between the new criminologists and legal scholars is well exemplified in Cantor's books and numerous articles. I plan to deal with Cantor at length in a study of developments from the late 1920s to the Second World War.

454. Francis B. Sayre, Mens Rea, 45 HaRv. L. Rev. 974 (1932).

455. Raymond Moley, Polmitcs and Criminal Prosecution (1929).

456. Jerome HAII, THEFT, LAW AND SOCIETY (1935).

457. JoHn Barker WAITE, CRIMINAI LAW IN ACTION 318 (1934) ("Without rancor or animosity, not as revenge or retribution, but solely as a necessary measure of public safety, we shall effectively and permanently eliminate them by death."). 
other strands of the legal-academic writings of the day left its mark on what became for a time one of the true foundation-stones of modern American criminal jurisprudence, Wechsler and Michael's 1937 article, $A$ Rationale of the Law of Homicide. ${ }^{458}$ That study largely fashioned a finesse of the traditional free-will problem and adopted a social-defense-based approach to deterrence, though it by no means utterly excluded the Progressive ideals of individualization and rehabilitation. Wechsler and Michael's contribution achieved a depth, a degree of internal coherence, and a clarity of overall system that contrasts markedly with Pound's corpus of criminal-justice scholarship. This contrast existed partly because Pound wrote before the theoretical groundwork had fully developed; partly because he thought that society was not ready for a major departure from its "hold-over" habits of belief and action; and partly because he took relatively little interest in the substantive law. But it existed largely, I suspect, because Pound never fully accepted the implications of what he termed the rout of the free-will doctrine for the traditional juristic approach to political liberty and the claim to human freedom. Pound invoked the new sciences and readily recognized, even claimed to welcome, their role in the future of criminal jurisprudence, but he never could bring himself to imagine what that future would look like. He rejected retributivism and said much else that could have led in the direction of one or another genre of the "social defense." But something - perhaps his particular form of belief in the human spirit, or his way of understanding old Progressive values, or his own brand of worldly wise common sense - kept him from ever openly endorsing that potentially stark penal theory, much less coming to terms with its increasing prominence in scholarly circles in the mid-to-late 1920s.

As a result, Pound's Progressive account of the state of criminal justice in America soon began to show its age. Indeed, not so long after publication of his lectures in 1930, the final chapter, "Criminal Justice Today," had, so to speak, become history, and the preceding

458. Herbert Wechsler \& Jerome Michael, $A$ Rationale of the Law of Homicide (pts. 1 \& 2), 37 Colum. L. REv. 701, 1261 (1937). Wechsler and Michael drew attention (id. at pt. 2, $1262-63$ \& n.7) to the modern positivists' mistaken belief that classical theory had been based solely on retributivism. Both schools, they claimed, had shared deterministic social defense premises - save for the Kantians and Hegelians within the classical school. The classical school had mainly looked to deterrence; the modem positivists to incapacitation and reformation; the penal theory of both, according to Wechsler and Michael shared deterministic premises. The popular and widespread belief among lawyers, as well as the public at large, was to the contrary. Perhaps because they focused on the underlying presumption of free will, Americans thought about responsibility and punishment in retributive terms. Pound was by no means attacking a ghost. 
historical chapters - masterful by any measure and all the more impressive when it is considered that Pound had worked on American criminal justice history in relative isolation - were left to gather dust. Sic transit: the legal and behavioral science writings of the mid-20s and beyond tested, as never before, the possibilities for a true integration of the insights of the new sciences with those of law, politics, and history. They tested, too, Americans' resourcefulness in interpreting the place of the crime problem in modern society, as well as in assessing the place of the conceptualization of criminality in modern social, political, and legal thought. The results - as we now know only too well - bore out Pound's prediction that "there will be much experimenting, some fumbling and much dissatisfaction." 459 But all of that is a story for another day.

\section{EPILOGUE}

We well know how central the problem that Speranza addressed in Medico-Legal Conflict remains to our law - and, more generally, to our lives. For most of us, whether we are always or only occasionally conscious of it, the search for a "pacificator" goes on. Just as the bifurcation of the legal process persists, so also does the division within our minds between the competing urges to explain causally and to affix blame, in the strong sense of criminal responsibility. From the Progressive Era forward, the rhetoric of the social and psychological causes of crime have vied - in the law, in the media, in ourselves - with the rhetoric of, and ineradicable belief in, human freedom. This ceaseless battle is only partly contained by the view that, though determining factors exist, they are typically not all-encompassing: that we - and those whom we blame have the wherewithal to resist, even if we lack the ability to draw the line between the resistible and the irresistible.

As has been the case for generations and perhaps centuries, we sometimes reflect these uncertainties in our tendency to soften the rigors of the sanctions to which we subject those whom we judge. 460

459. Pound, supra note 266, at 588.

460. For a particularly effective evocation of this theme, see LLOYD L. WEINREB, OEDIpus at Fenway Park: What Rights Are and Why There ARe ANy 40-55 (1994) [hereinafter WeINREB, OEDIPUS AT FenWAY PARK]. Weinreb states that "Human responsibility is a structural fact of our experience. By 'structural fact' I mean a proposition that cannot be contradicted without altering the nature of our existence, not merely in some concrete particular(s) but in a fundamental way, making it a different experience entirely." Id. at 45 . He then deftly notes the ways in which we also order our experiences in accordance with the natural world, stating that (with respect to criminal responsibility): "In practice, we often split the difference, our uncertainty whether the person is truly responsible at all mitigating the punishment." Id. at 54. Weinreb concludes: 
Doubts about the reality of criminal offenders' autonomy have sometimes played a role in the movement to abolish, or greatly reduce the reach of, the sanction of capital punishment. 461 Those to whom it seems equally irrational "merely" to incarcerate an offender on the basis of criminal responsibility may be partly appeased by the thought that the chief goal of imprisonment is rehabilitation. Punishment is then viewed as at least largely benign and responsive to the deterministic aspect of human life. This maintains the bifurcated regime of the criminal law but brings a needed peace of mind.

On the very long view, we have grown increasingly aware of the fragility of our own autonomy and increasingly concerned that punishment conjoin a great deal of cure for "illness" with a moderate degree of deterrence and retribution. But up close, the path of ideas about criminal justice has hardly been linear. It has been, rather, either subject to brief moments of atavism or downright cyclical. We are, as I write, at an especially tense moment - and a lengthy one at that: for several decades now, the ideal of rehabilitation has been under significant pressure. ${ }^{462}$ To some extent we have responded to the observation that the indeterminate sentence does not work. Our calls for fixed sentences and our critique of rehabilitation are thus premised in part on the view that a return to older ways is fairer to those we hold responsible and even accords them a greater degree of human dignity. To some extent, too, we simply express our anger, and our natural fears of crime. Not least, however, we seem increasingly captured by the notion that we have gone too far in the direction of absolving one another of personal responsibility. It seems entirely plausible that the due-process and

The antinomy of freedom, the opposition between the natural order and the moral order, is complete and unavoidable. As an idea of reason, freedom is not within our grasp.

If abstract reason thus fails decisively, there remains an issue that is all the more press-

ing: how within our experience the antinomy is resolved. For, perforce, it is resolved.

Id. at 55. Weinreb focuses in this book on the "resolution" of the "antinomy" with respect to rights. (He develops his own thoughts on the relationship between the freedom issue and criminal responsibility in LLOYD L. WEINREB, NATURAL LAW AND JUSTICE 184-265 (1987) [hereinafter WeINREB, NATURAL LAW AND JUSTICE]). My own brief and selective commentary notes some of our lay and professional legal practices (I dare not term them "resolutions") with respect to criminal responsibility. In that regard, if one were to seek "resolutions," in the sense of philosophically defensible propositions - as distinct from a description of mainly unselfconscious practices - one might well begin with recognition of the "antinomy of freedom" that Weinreb outlines. I hardly know where such a quest would lead, beyond the belief (which I hold) that "splitting the difference" is a step - currently, far too small a step - in the right direction.

461. GREEN, supra note 14, 267-317, 378-79, 382.

462. The classic account of the rise and "decline" of the ideal of rehabilitation remains ALIEN, supra note 6. 
equal-protection based arguments for fixed sentences and for guidelines that ensure that such sentences will not vary from judge to judge reflect a desire to strain out, to a large degree, consideration of background "causal" factors that "led" to the crimes for which the fixed and fair sentences are imposed. If so, theories of will once again come to the fore; the recrudescence of pre-Progressive-Era ideas trades on an endorsement of the dignity of the individual and attention to personal responsibility, so that the resulting approach to sanctions owes nothing - apparently - to a modern version of the theory of incapacitation solely in the social defense.

Within the legal world of bench, bar, and academy, as in society at large, the traditional and fundamentally unstable view prevails: Wharton's pact with the angels survives, albeit often in an attenuated form. Nor have the values associated with the traditional view altered: political liberty, human dignity, and freedom of the will remain intertwined. Perhaps Professor Kadish has put the matter as well and wisely as anyone:

Much of our commitment to democratic values, to human dignity and self-determination, to the value of the individual, turns on the pivot of a view of man as a responsible agent entitled to be praised or blamed depending upon his free choice of conduct. A view of men "merely as alterable, predictable, curable or manipulatable things" is the foundation of a very different social order indeed. The ancient notion of free will may, in substantial measure, be a myth. But even a convinced determinist should reject a governmental regime which is founded on anything less in its system of authoritative disposition of citizens. Whether the concept of man as responsible agent is fact or fancy is a very different question from whether we ought to insist that the government in its coercive dealings with individuals must act on that premise. ${ }^{463}$

If indeed we "ought to insist ...," we ought also to expect that tensions within the law, and within ourselves as we act out the law's imperatives, will be with us to the end.

In the academy, to be sure, neo-realist analyses and critiques have exploded long-standing orthodoxy: the legal designations of "free" and "unfree," hence guilty or innocent under the criminal law, have been portrayed as conclusions determined by political, social, or psychological circumstances, much in the same way that findings of proximate cause, duty, or a meeting of the minds were portrayed by the realists three-quarters of a century ago. Moreover, the very distinction that legal scholars typically draw between

463. Sanford H. Kadish, The Decline of Innocence, 26 CAMBRmGE L.J. 273, 287 (1968) (quoting H.L.A. HART, Punshment AND ResponsIBILITY, 182 (1968)), reprinted in SANford H. Kadish, Blame and Puntshiment. Essays in the Criminal Law 65, 77 (1987). 
free will and determinism has sometimes been derided as a false dichotomy between "denatured choices." 464 The law, some seem to suggest, should instead look to the role of culture - to prevailing standards of behavior, and to the beliefs that surround behavior, and, especially, to the interaction of "self" and culture - in establishing appropriate guidelines for the attribution of criminal responsibility. It is not always easy to decipher the perspective on the freedom issue that accompanies this approach. One is tempted at times to think that, here, yet another form of determinism appears as one of the innumerable forms of compatibilism that the modern mind has constructed in its determined search for a place to stand and to judge. However that may be, it is important to note that the new academic stances - neo-realist, critical-legal, or postmodern - remain largely theoretical accounts of the nature of law and of human behavior. Their application in practice might be evidenced at the margins as they come to influence the minds of some judges, lawyers, and penologists. But given their inevitable distance from our current politics, they are even more foreign to society at large than were the ideas of fin de siècle criminal anthropologists and inter-war realists, especially with regard to the core issue of personal responsibility - the assessment of criminal guilt. 465

464. Robert Weisberg, Criminal Law, Criminology, and the Small World of Legal Scholars, 63 CoLO. L. REv. 521, 543 (1992). Weisberg supplies cogent observations on some of the issues I am briefly addressing here.

465. It remains unclear where the extensive and illuminating academic discussion of the free-will issue regarding criminal responsibility - the "conversation" of recent decades will lead. I make no attempt to provide a guide to this vast literature. In addition to Weinreb, see WeINREB, Natural LaW aNd Justice, supra note 460; WeInREB, Oedipus at FENWAY PARK, supra note 460, and Nussbaum's splendid article, see NussBaum, supra note 25 , some of the relevant works, by legal scholars, behavorial scientists, and philosophers, are noted in the important contributions of John L. Hill, Note, Freedom, Determinism, and the Externalization of Responsibility in the Law: A Philosophical Analysis, 76 GEO. L.J. 2045 (1988); Mark Kelman, Interpretive Construction in the Substantive Criminal Law, 33 STAN. L. REv. 591 (1981); Weisberg, supra note 464; POSNER, supra note 25, at 161-86; Meir DanCohen, Responsibility and the Boundaries of the Self, 105 HARv. L. REv. 959 (1992).

In his challenging account, Judge (and Professor) Posner notes the congruence among a behaviorist approach, the goal of deterrence, and what we normally think of as a free will based framework of substantive rules. POSNER, supra note 25, at 161-96. Judge Posner doubts that recognition of our pervasive behaviorist assumptions will much affect the way we think and act in everyday life:

A behaviorist metalanguage will not sap people of their sense of moral responsibility .... Philosophers who believe in determinism behave in their personal lives just like other people. If freedom is an illusion, it is one of those illusions . . . that we cannot shake off no matter what our beliefs or opinions are. And there is no mystery about the survival value of the illusion (if that is what it is) of freedom, and thus no mystery about why it may be hard-wired into our brains. The feeling of freedom forces us to act deliberately, in the sense of gathering as much relevant information as possible concerning the pros and cons of alternative courses of action before we act.

Id. at 178. As my own quite tentative comments suggest, I believe that behaviorist ideas have indeed produced deep and widespread tensions. It remains to be seen whether Judge Posner will succeed in his attempt to allay such tensions through his own particular form of rational 
For the most part, as we well know, academic concern with the mysteries of human free will remains just that: academic. In our more public capacities, if not always in our teaching and theorizing in print, we mainly indulge the presumption that underpins the law. As a group, we may express more skepticism about free will than other elements of the legal caste, and so might, like some of our predecessors, endorse, inter alia, broader definitions of legal insanity, but - perhaps out of allegiance to the consciousness of human freedom - when we act in the real world we are, most of us, not so very far from society at large. Like Pound, we leave the working out of the most difficult problems to the future. We play a role defined for us by our culture and our psychology, as generations of legal academics have before us and as those that follow probably will as well. This is a particularly influential role. To be sure, it is only one of many guideposts for our culture at large, and, no doubt, politicians and religious leaders, among many others, send signals that have greater impact upon greater numbers, so far as the affirmation of human freedom is concerned. But as perceived guardians of the rules and underlying theories of the law, we hold a special place. If we are a relatively small part of the legions whose destiny it is to reinforce faith in human freedom - political liberty as well as free will, I ought to add - the work of our particular cadre is nonetheless relatively significant.

The current widespread obsession with personal responsibility, it should be noted, reflects a reaction not only against this century's increasingly deterministic rhetoric regarding the causes of criminal behavior, but also against what are taken to be the deterministic assumptions that pervade the welfare state generally. These assumptions relate both to noncriminal and criminal concerns, as government initiatives affect existing concepts of just deserts in distributive justice, regarding, inter alia, property and contract, as well as in retributive justice, the traditional domain of the criminal law. Progressivism is carried forward, but it is also under profound attack across the spectrum of political and social thought. In this, our politics have produced a macrocosmic reflection of the microcosmic experience within each of us.

discourse. His discussion has much to offer as an "external" account of both the law and of human behavior. From an "internal" perspective - either of the condemner or the condemned (to take the most extreme case) - self-consciousness about the possibility that the consciousness of freedom is "hard-wired" might prove unsettling. This suggests that the nature and degree of "punishment" (if we punish) ought to bear significant relation not only to the goal of deterrence, but also (as perhaps Judge Posner would agree) to our uncertainties about human behavior. 
But who is "us"? Society as a whole is deeply divided between the heirs to Progressivism and those who have now rejected, or who never accepted, its message for criminal justice. Disagreements on responsibility not only track, in the large, religious, social and other alignments, but are also, of course, internal to those and other perspectives, including the recent movements along racial, ethnic, and gender lines. This is not the place for a rehearsal of the multifaceted role of the free-will-determinism issue in modern American society. Nor - even if it were - am I well-suited to undertake such a task. I want only to say that the issue is still very much with us and that, with respect to criminal justice, we are more conflicted than ever. Conflicted to the point that our attitudes defy generalization. The main direction of our present thought and behavior depends entirely on the eye of the beholder. If we tend to speak with greater confidence about main directions in the past, that may well be due to the increased perspective that a historical view affords. Which is to say that we know very little about the past and too much about the present.

About the inscrutable present we might nonetheless venture some final commentary along the lines marked out by our discussion of Speranza and Pound. Speranza was an American lawyer, but at the start of his career he looked at American law from the outside, with ties to, and an understanding of, the continental tradition, and with the sympathies of the scientist. Pound was well inside the common law tradition, albeit - early on - among its more progressive spirits and trenchant critics. Pound's brand of Progressivism propelled him to the forefront of the academy, but it also set limits to his worldview and to his understanding of the relationship of law to behavioral science. It engendered a certain confidence and even complacency as it focused his gaze on overall social functionalism rather than on specific human motivations. I have illustrated that tendency in Pound partly in terms of his understanding of the role of the jury. In 1909 he saw ad hoc jury law-finding as at least in part a useful and progressive antidote to the rigidity and old-fashionedness of the law; by 1920, he mainly saw it not only as anachronistic, but also as dysfunctional in a society that had, across the Progressive years, indulged in the rhetoric of rational decisionmaking and institutional coordination.

From our own perspective, the optimism of the Progressive Era and of Pound's majestic account seems a mite naive. And the irreducible problem of human freedom thus looms all the larger. The story of the post-1925 period — as yet untold - has an ending with 
which we are familiar. On the most fundamental issue, that of human accountability, we have made little progress. This is reflected as much as anywhere in our own thinking about the jury, which is, to be sure, more complex than was Pound's. We are still to great extent history-bound, although for us history includes the rights revolution of the post-World-War-II era and the dramatic developments in participation on juries of women, and Blacks, and of many ethnic groups that formerly were not represented. But our perspective on the jury is also characterized by our awareness of the impact, subconscious or otherwise, of some of the newest forms of "science" on those who serve. We do not often focus on the phenomenon of bifurcation, as such, but our instincts about what jurors may appropriately take into account reveal conflict about longsettled, formal divisions of power. In truth, the rhetoric of determinism is now so pervasive that we cannot fully understand the role of the jury without taking account of the fact that we sometimes ask that institution to resolve an issue on which we are deeply divided, not only between groups but also within ourselves. We alternately condone or condemn a particular jury that at least seems to have applied some notion of mitigated responsibility to which the law does not formally give recognition. Sometimes we recognize how contradictory we are in this regard; sometimes we do not.

In thinking about the relationship between the criminal trial jury and the duality of our responses to those whose actions displease us - our tendencies to blame or to explain away - we ought to recall that the jury is both constrained by legal rules and a plaything of social forces. That relationship has, therefore, taken a variety of forms: At times the jury has been relatively resistant to expression of doubts about human freedom; at others it has allowed their expression fairly freely. Even when jurors or members of society at large have expressed such doubts, they have usually done so in the spirit of recognizing in a particular case an exception to what they perceive in general as valid rules regarding responsibility. Thus, when the jury has gone outside the rule of law, it has often fortified the presumption of human freedom by providing a release point where otherwise that presumption might have been called into doubt. In this fashion, the jury has at times functioned as a legitimator at the trial stage, just as some substantive doctrines have done against the background of the unprovable premise that underlies our traditional theory of criminal responsibility. ${ }^{466}$ That has not

466. NORRIE, supra note 14. Norrie's important book deals with the legitimating function of free-will-based rules of law, but does not focus on the question whether juries sometimes 
necessarily been anyone's intention, any more than we are necessarily selfconscious about the way we - in our private lives shore up our own blaming instinct by giving way in particular instances where insistence upon blame might lead us to suspect, rightly or wrongly, that there is always something rationally indefensible about that insistence.

The legal constraints within which juries operate can, of course, be understood as reflections of the interests of authorities in husbanding the power to withhold or to grant release from the rules of responsibility on their own terms. ${ }^{467}$ But that does not do full justice to the long history of the jury's power to find, or to nullify, the law. The English bench has at times encouraged juries to play that very role, at times sought to set distinct but far from total limits on that practice, and at times attempted to eliminate it altogether. ${ }^{468}$ On the American side, the story has been - and remains equally complex. From yet another perspective, limitations upon the jury have often reflected attention to the rule of law as a general matter and have been only incidentally related to, though they may have had significant impact upon, the tensions regarding responsibility that I have been discussing.

Finally, jury nullification in cases involving the issue of human autonomy bears an important relationship to jury nullification in so-called political cases. In the latter, the jury is often in the position of affirming human freedom: even where the jury is mainly registering opposition to a particular law, the defendant who is thereby treated mercifully is sometimes thought to have challenged that law on the basis of deep moral beliefs, of his or her own free will. This is the tradition of jury latitude that was long the backbone of the jury law-finding doctrine and it remains central to the modern jury nullification debate. ${ }^{469}$ Social and legal recognition of

play this role. For an excellent review of Norrie's book, see Nicola Lacey, Abstraction in Context, 14 OXFord J. Legal STUD. 255 (1994).

467. This is the general tenor of Norrie's position. NORRIE, supra note 14.

468. GREEN, supra note 14. It is, of course, possible to construe the "encouragement" to which I refer as itself an aspect of the long-range strategy of the ruling classes to maintain their hegemony. I have portrayed judicial thought and behavior in eighteenth-century England - historiographically, an embattled terrain - as in part conditioned also by widespread social mores regarding the sanction of capital punishment. Id. at 267-317. These mores, too, I suppose, can be viewed as aspects of culture that reflect the hegemony of the ruling classes. But so too can they be understood as reflections, in institutional practices, of deep-seated attitudes that have not been successfully coordinated "from above." Who has ruled whom, in particular contexts, remains a perplexing question for every historian of criminal justice, and not least for historians of the criminal trial jury.

469. Id. For an excellent study of the modem nullification problem, see JEFFREY ABRAMSON, WE, THE JURY: THE JURY SYSTEM AND THE IdEAL OF DEMOCRACY (1994). 
the legitimacy of this form of jury behavior - or even mere toleration of its occasional manifestation - cannot help but fortify jury nullification where the jury disaffirms human freedom, most notoriously, in some cases where the defendant has raised a legal insanity defense. But also, more generally, in routine criminal cases, where juries have sometimes responded intuitively to what might be termed commonplace social constraints upon freedom of thought and action. There has never been, in the Anglo-American tradition, an effective separation between arguments for jury-based lawfinding in these very different kinds of cases. ${ }^{470}$ The age old practice of freedom-disaffirmance, in its most general forms, has traded on the longstanding tradition of freedom-affirmance in cases raising the question of political liberty, and vice versa. Indeed, the writings of Speranza and Pound reflect the interchange between these types of cases in differing, but related ways.

I have, on another occasion, alluded to an important aspect of the relationship among the English criminal trial jury, law reform, and the problem of responsibility that we do well to keep in mind as we attempt to situate Pound in relation to our own time and place. ${ }^{471}$ The reform of sanctions in the early Victorian era may have been undertaken in part as a reaction to the tendency of jurors to give weight to the social conditions that produced crime as they searched for reasons to nullify the capital sanction for what they viewed as less than the most heinous offenses. Here, the interests of political and legal authorities in maintaining the integrity of the orthodox theory of responsibility mixed with their interests in deterrence and in simple humanitarianism. The reform of sanctions then combined with ongoing property qualifications for jury service and with the development of a culture of deference to the bench to produce over time a self-restrained English criminal trial jury. Some early-twentieth-century American critics of the criminal trial jury, including Pound, drew lessons from the English experience and sought to make over the American trial in the image of its English counterpart. But not all such critics shared the same agenda. Among the common lawyers, Pound was, if not unique, something of an odd man out.

Pound wrote about the sources of the extensive powers of the American jury at some length. For the most part, he situated the jury within the history of political liberty. With respect to human 55.

470. For a discussion of this issue on the English side, see GREEN, supra note 14, at 349-

471. Id. at 383 . 
autonomy, he stressed, as we have seen, jury-based acceptance of the frontier urges of vindication of honor - the assertion of individual liberty - rather than jury-based recognition of the social and psychological constraints upon human freedom. Pound favored a more limited role for the jury, but not in order to shore up the orthodox common-law theory of criminal responsibility. Rather, he deemed jury-based law-finding dysfunctional precisely because, whether it was progressive or retrogressive, it was relative to a theory of responsibility that was itself irrational. Pound sought to husband for the bench the powers that the positivists sought to reserve for scientific experts, and like the positivists, he did so in the name of substituting a new theory of responsibility for the orthodox freewill-based theory of common law criminal jurisprudence.

Pound's hopes for a true melding of law, science, and morals came to naught; even he could not squarely confront the implications of the sermon he preached. The positivist program relative to a new applied theory of criminal responsibility has largely collapsed. Orthodoxy has prevailed, albeit amidst the heightened tensions produced by the rhetoric regarding the causes of criminal behavior that the positivists boldly set in motion and the Progressives furthered in their own more tentative fashion. This is the situation in which modern American society, including the institution of the criminal trial jury, now finds itself.

We are confronted daily with evidence that seems to confirm Pound's insistence upon a particular form of American exceptionalism (our "frontier attitude") regarding the intensity of our attraction to individual rights, the frequency of our resource to violent self-help, and the depths of our suspicion of the state. What Pound deemed an unhealthy, "held-over" attachment to will theory probably strikes some as Americans' ongoing embrace of the deepest truth, others as recourse to a useful belief (conducive both to the preservation of political liberty and the cultivation of a sense of personal well-being), and still others as too great a rejection of what like it or not - we already know about the nature of our selves. Among even these last there may be some who nonetheless believe that an appropriate balance between the "religion" of free will and the "science" of determinism is struck in the rituals by which we now live. And among these rituals are the practical and symbolic aspects of jury-based determination of guilt - in some cases, of punishment - in accordance neither with pure legal abstraction nor with supposed scientific precept, but, as we are wont to say, with the "common sense" and the "conscience of the community." 
Perhaps as testimony to this perspective, the phenomenon of bifurcation of the criminal process has developed increasing prominence. In capital cases, to take a leading, though admittedly exotic, example, the sentencing stage in most states is left in the hands of the jury, so that the same persons first assess guilt on the basis of the limiting terms of the law of evidence and then, if they convict of capital murder, sometimes reassess it (de facto) in the context of affixing punishment in light of information that, had it been before them at the trial stage, might have led them to a different result. The ad hoc aspect of lay decisionmaking has been harnessed to the process at sentencing - the potentially more "scientific" stage - a turn of events that would have appalled Pound even as it might have pleased the Speranza of 1901. Decisions must not only be made, they must also be lived with. So, too, must incoherence be lived with, and - evidently - its lessons allowed to temper our judgment as we, case by case, see fit. Not only with respect to the marketplace wherein Professor Dawson traced the history of economic duress, but in the domain of criminal justice administration as well. Perhaps there more than anywhere. For it is one thing to observe academically that we can't prove beyond a reasonable doubt that the defendant was a free agent; it is another actually to have to pass judgment upon persons who society has agreed must be held responsible - indeed, who are said to have a right both with respect to human dignity and as against overweening political authority to be conceived of as personally responsible. The resulting tension can be very great, and the ritual of judgment is sometimes no less than an act of faith. One feels a certain truth - shall we say, a certain consolation? - in the observation that, after all (let Speranza's words be my last): "Law is one of the Humanities." 